\title{
Management of Municipal Waste in the EU Member States: Best Practices
}

Jiř́ Zicha, Lenka Smékalová, Olga Kapplová, Liudmyla Golovko 



\section{Management of Municipal Waste in the EU Member States: Best Practices}

Jiř́ Zicha, Lenka Smékalová, Olga Kapplová, Liudmyla Golovko 
KATALOGIZACE V KNIZE - NÁRODNÍ KNIHOVNA ČR

Zicha, Jiři

Management of municipal waste in the EU member states : best practices / Jiři Zicha, Lenka

Smékalová, Olga Kapplová, Liudmyla Golovko. -- Order of issue: first, issued electronically. -- In

Zlin : Tomas Bata University, 2021. -- 1 online zdroj

Obsahuje bibliografii a bibliografické odkazy

ISBN 978-80-7678-055-2 (online ; pdf)

$* 628.4 * 628.3 / .5 *(048.8: 082)$

- komunální odpad -- země Evropské unie

- odpadové hospodářství -- země Evropské unie

- kolektivní monografie

628 - Sanitární technika. Vodárenství. Odpadové hospodářství. Světelná technika [19]

Authors:

JUDr. Jiř́ Zicha, Ph.D., Ing. Lenka Smékalová, Ph.D., JUDr. Olga Kapplová, Ph.D. - Tomas Bata University in Zlin

Dr. Liudmyla Golovko, Ph.D. - National University of Life and Environmental Sciences of Ukraine

Graphic design and typesetting: Jiř́ Zicha

Publisher: Tomas Bata University in Zlin, 2021

Order of issue: First

Issued electronically

Scientific editor: doc. Ing. Adriana Knápková, Ph.D.

Reviewers: Dr. Viktoriia Halai, Ph.D., JUDr. Ondřej Vícha, Ph.D.

(C) Jiří Zicha, Lenka Smékalová, Olga Kapplová, Liudmyla Golovko 2021

ISBN 978-80-7678-055-2 


\section{Table of Contents}

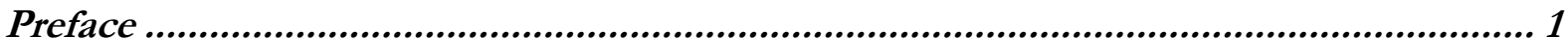

1 Management of municipal waste in the European Union .................................... 3

1.1 Legal and institutional framework of waste management .....................................3

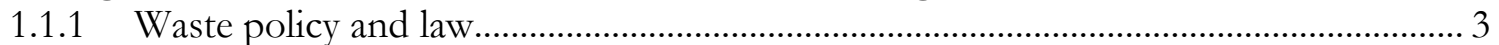

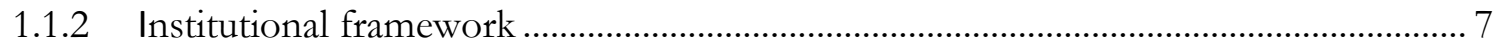

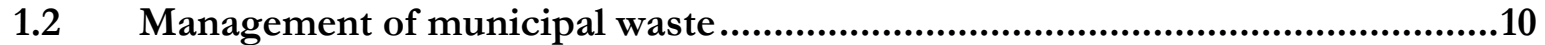

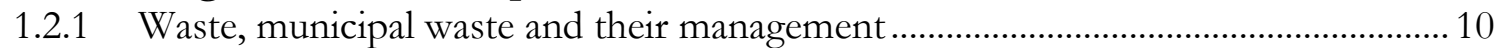

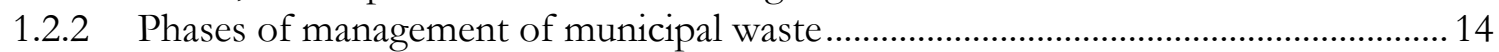

1.2.3 Treatment of specific components of municipal waste............................................... 22

2 Management of municipal waste in selected EU Member States ........................ 33

2.1 Management of municipal waste in the Czech Republic................................. 33

2.2 Management of municipal waste in Poland ................................................. 39

2.3 Management of municipal waste in Slovakia ............................................... 44

3 Contribution of the EU Cohesion Policy to the management of municipal waste .. 47

3.1 Pre-accession assistance to the Czech Republic ............................................... 47

3.2 Contribution to the Member States: Czech Republic......................................50

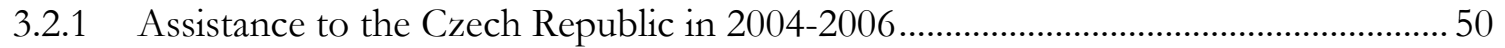

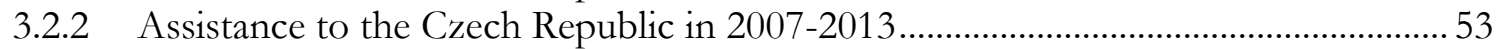

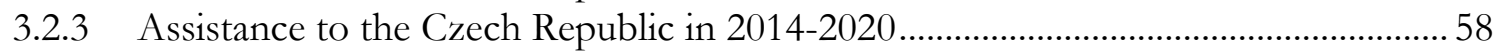

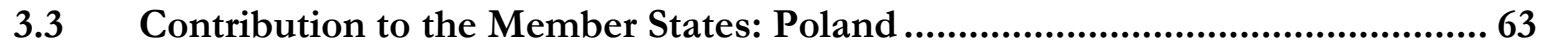

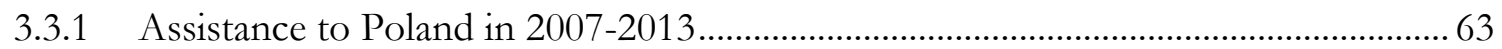

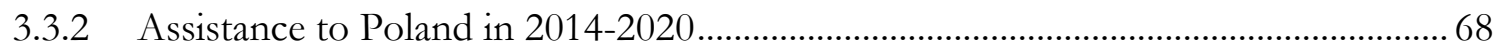

3.4 Contribution to the Member States: Slovakia ............................................. 73

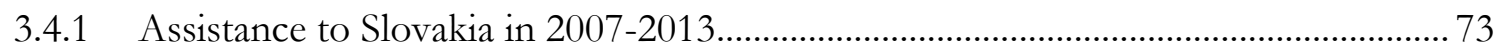

3.4.2 Assistance to Slovakia in 2014-2020 ……...................................................................... 77

4 Conclusion and lessons learned for Ukraine ....................................................81

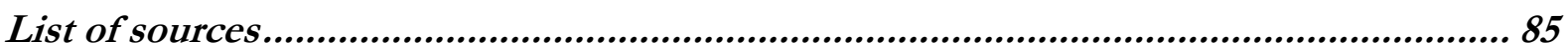




\section{Preface}

This monograph has been prepared within the framework of the joint Ukrainian-Czech Republic scientific project called the EU Environmental Policy on Solid Domestic Waste Management and its Implementation in Ukraine and the Czech Republic, which has been implemented from 2019 to 2021 by the National University of Life and Environmental Sciences of Ukraine and Tomas Bata University in Zlin.

The main objective of this publication is to provide an overview of the legal and institutional framework of waste management in the European Union and its Member States and to present an analysis and evaluation of individual aspects of such management and its phases. Although it mainly deals with solid municipal waste, it also provides broader perspectives and includes additional elements of waste management. Furthermore, it brings a description and analysis of financial tools used mainly within the Cohesion Policy for contribution to effective implementation of waste management. It also collects examples of best practices in the field of solid municipal waste management.

As for the methods that have been used, in the case of Chapters 1 and 2, the basic one is the analysis of texts, in particular legal norms, case law, guidelines, and other related documents, both on the overall European level and the individual Member States. The legal framework for waste management, similarly to the entire environmental law, is already relatively complex and dynamic at the same time. Therefore, attention must be paid to the main ideas and principles, together with ongoing trends and potential options. In addition to that, the idea is also to provide practical examples of everyday implementation. Therefore, the following method has been the collection and analysis of examples of best practices. Chapter 3, which is dealing with economic instruments, follows on from this. All the Member States implement the cohesion policy based on a common legal framework that requires them to publish certain information and documents as means of public control. The implementation of policy is based on legally required strategic documents. Therefore, every country is described in terms of the stance individual Member States declare towards the waste management investments in general and solid waste management in particular in these strategic documents. In the 2007-2013 programming period, these documents were titled the National Strategic Reference Framework. In the following period, 2014-2020, their name was the Partnership Agreement. The following is the description of individual operational programmes that dealt with investments in waste management operations in all countries. Finally, the individual projects are analysed as per the public lists of beneficiaries alternatively lists of operations. Projects (operations) are described, if possible, based on their numbers, thematic focus, spending, applicants, and in terms of spatial distribution. At the project level, it was in the majority possible to identify investment operations related to solid municipal waste with minor inconsistencies regarding projects of private applicants that can focus on both solid municipal waste and industrial waste in a single project. Only if ties to solid municipal waste were in evidence were such projects considered in the analysis. The chapter is particularly focused on the experience of the Czech Republic, owing to the countries involved in the project which financed this publication. Therefore, the Czech Republic is analysed in terms of a more extended period, from pre-accession aid to 2020. It is necessary to note that a low level of information available characterizes the pre-accession period and the initial membership period 2004-2006. However, to make the experience with the cohesion policy more comparable and relatable to Ukrainian expectations, the member states of Poland and Slovakia are also included for the more recent programming periods of 2007-2013 and 2014-2020, which are relatively well documented across all countries. Their inclusion helps illustrate a broader extent of approaches to investments related to solid municipal waste management. 
The main scientific contribution of the publication is the elaboration of a qualitative comparative study of legal and institutional frameworks within the selected EU Member States, supplemented by the analysis of the system and possibilities of utilization of the financial funds. It also provides an overview of implementation in practice at different hierarchical levels, i. e. the European, national, regional, and local. It may serve for practical use in the academic, public and private sectors in the Czech Republic and Ukraine, both to gain an overview of the current setup of the system of solid municipal waste management and especially for its further optimization and modernization.

Hopefully, this publication may also become another piece in the puzzle of understanding and improving waste management in our countries.

Authors, Zlin and Kyiv, September 2021 


\section{Management of municipal waste in the European Union}

Jiř Zicha

The European Union is founded on the Treaty on European Union (TEU) and the Treaty on the Functioning of the European Union (TFEU). ${ }^{1}$ According to the TEU, the Union is founded on the values of respect for human dignity, freedom, democracy, equality, the rule of law and respect for human rights, including the rights of persons belonging to minorities. These values are common to the Member States in a society in which pluralism, non-discrimination, tolerance, justice, solidarity and equality between women and men prevail. ${ }^{2}$ The Union shall establish an internal market which shall work for the sustainable development of Europe based on balanced economic growth and price stability, a highly competitive social market economy aiming at full employment and social progress, and a high level of protection and improvement of the quality of the environment. It shall also promote scientific and technological advances. ${ }^{3}$

The general legal framework established by the TEU is further specified in TFEU. Its title XX called Environment provides a legal basis for the Union's environmental policy. This policy shall contribute to the pursuit of the objectives of preserving, protecting and improving the quality of the environment, protecting human health, to prudent and rational utilization of natural resources, and promoting measures at the international level to deal with regional or worldwide environmental problems, and in particular combating climate change. In preparing its policy on the environment, the Union shall take account of available scientific and technical data, environmental conditions in the various regions of the Union, the potential benefits and costs of action or lack of action, and the economic and social development of the Union as a whole and the balanced development of its regions. ${ }^{4}$

Nevertheless, the environmental policy is not a self-standing or isolated activity. On the contrary, the TFEU states that environmental protection requirements must be integrated into the definition and implementation of the Union's policies and activities, in particular with a view to promoting sustainable development. ${ }^{5}$

All these grounds are also relevant for managing waste, respectively the municipal waste, and they need to be kept in mind during the adoption and implementation of measures in this field.

\subsection{Legal and institutional framework of waste management}

\subsubsection{Waste policy and law}

EU waste policy occupies an essential place within the Union's environmental portfolio. It also has a long lineage, starting from the Commission's 1972 Communication on the EC Programme on Environment, where the focus was on reducing waste generation and recycling. Since then, waste management has been recognised as a priority area in all EU Environmental Action Programmes (EAPs). The Second (1977) and Third (1983) EAPs emphasised the objective of the three-step waste hierarchy in the context of protection and management of natural resources. In 1989, the Commission adopted the First Community Strategy on Waste Management which provided a comprehensive and strategic approach to the implementation of EC waste policy.

\footnotetext{
${ }^{1}$ Consolidated versions of the Treaty on European Union and the Treaty on the Functioning of the European Union, OJ C 326, p. 1-390.

2 Article 2 TEU

3 Article 3 TEU

4 Article 191 TFEU

5 Article 11 TFEU
} 
The strategy builds upon the concept of waste hierarchy comprising prevention of waste generation and promotion of recycling and reuse. The same approach was endorsed in the Sixth EAP (2002), which also established ways prevention and management is one of its key environmental priorities. ${ }^{6}$ The Seventh $\mathrm{EAP}^{7}$ was adopted in 2013 as a guiding document of European environment policy until 2020. To give more long-term direction, it also sets out a vision beyond that of where it wants the Union to be by $2050 .^{8}$ It has identified three key objectives: to protect, conserve and enhance the Union's natural capital, to turn the Union into a resource-efficient, green, and competitive low-carbon economy, and to safeguard the Union's citizens from environment-related pressures and risks to health and wellbeing. ${ }^{9}$ The proposal of the Eighth EAP is currently being discussed. ${ }^{10}$

Soon after the adoption of the First EAP, the Directive on waste oils ${ }^{11}$ and Directive on waste ${ }^{12}$ were adopted in 1975, which paved the way for considerably legislative activism in this policy area. The Directive on the waste provided an appropriate legal framework for implementing EC waste policy for the first time. Although the essential objective of waste disposal was the protection of human health and the environment against any harmful effects, the preamble of the Directive seemed to focus more on the need to regulate waste to avoid any distortion of competition in the common market. Still, the Directive set out a definition of waste and introduced the waste hierarchy and polluter pays principles. ${ }^{13}$

Since then, the EU waste law has been developed into one of the most extensive and comprehensive parts of the environmental acquis that attempts to cover all activities that may generate waste. It tends to be highly technical and requires the Member States to invest in developing waste management infrastructure and waste treatment technologies and developing administrative capacities. ${ }^{14}$

We may distinguish several areas covered by the $\boldsymbol{E} \boldsymbol{U}$ waste law. The general framework is provided by

- Directive on waste, ${ }^{15}$

- Directive on the landfill of waste, ${ }^{16}$

- Regulation on shipment of waste ${ }^{17}$ and

\footnotetext{
${ }^{6}$ KINGSTON, S., HEYVAERT, V., ČAVOŠKI, A. European Environmental Law. Cambridge University Press, 2017, p. 490.

${ }^{7}$ Decision No 1386/2013/EU of the European Parliament and of the Council of 20 November 2013 on a General Union Environment Action Programme to 2020 'Living well, within the limits of our planet', OJ L 354, p. 171-200.

8 Ibid., p. 176: In 2050, we live well, within the planet's ecological limits. Our prosperity and healthy environment stem from an innovative, circular economy where nothing is wasted and where natural resources are managed sustainably, and biodiversity is protected, valued and restored in ways that enhance our society's resilience. Our low-carbon growth has long been decoupled from resource use, setting the pace for a safe and sustainable global society.

${ }^{9}$ EUROPEAN COMMISSION. Environment Action Programme to 2020. Available online at https://ec.europa.eu/environment/action-programme/.

${ }^{10}$ EUROPEAN COMMISSION. Environment Action Programme to 2020. Available online at

https://ec.europa.eu/environment/strategy/environment-action-programme-2030_en.

${ }^{11}$ Council Directive 75/439/EEC of 16 June 1975 on the disposal of waste oils, OJ L 194, p. 23-25.

${ }^{12}$ Council Directive 75/442/EEC of 15 July 1975 on waste. OJ L 194, p. 39-41.

${ }^{13}$ KINGSTON, S., HEYVAERT, V., ČAVOŠKI, A. European Environmental Law. Cambridge University Press, 2017, p. 489-490.

14 Ibid., p. 491.

${ }^{15}$ Directive 2008/98/EC of the European Parliament and of the Council of 19 November 2008 on waste and repealing certain Directives. OJ L 312, p. 3-30.

${ }_{16}$ Council Directive 1999/31/EC of 26 April 1999 on the landfill of waste. OJ L 182, p. 1-19.

${ }_{17}$ Regulation (EC) No 1013/2006 of the European Parliament and of the Council of 14 June 2006 on shipments of waste. OJ L 190, p. 1-98.
} 
- Regulation on waste statistics. ${ }^{18}$

Specific rules for waste from consumer goods are set by

- Directive on packaging, ${ }^{19}$

- Directive on light-weight plastic bags, ${ }^{20}$

- Directive on single-use plastics, ${ }^{21}$

- Directive on end-of-life vehicles, ${ }^{22}$

- Directive on type-approval of motor vehicles, ${ }^{23}$

- Directive on batteries and accumulators, ${ }^{24}$

- Directive on electrical and electronic equipment, ${ }^{25}$ or

- Directive on the restriction of the use of certain hazardous substances in electrical and electronic equipment. ${ }^{26}$

Another set of provisions is focused on waste which is generated within specific activities, such as

- agriculture, ${ }^{27}$

- extractive industries ${ }^{28}$ or

- ship transportation. ${ }^{29}$

Special attention is also paid to the transboundary movement of hazardous waste and its international legal framework set by the Basel Convention. ${ }^{30}$ In the framework of Euratom is regulated radioactive waste and its shipments ${ }^{31}$ and management. ${ }^{32}$

${ }^{18}$ Regulation (EC) No 2150/2002 of the European Parliament and of the Council of 25 November 2002 on waste statistics. OJ L 332, p. 1-36.

${ }^{19}$ European Parliament and Council Directive 94/62/EC of 20 December 1994 on packaging and packaging waste. OJ L 365, p. 10-23.

${ }^{20}$ Directive (EU) 2015/720 of the European Parliament and of the Council of 29 April 2015 amending Directive

94/62/EC as regards reducing the consumption of lightweight plastic carrier bags. OJ L 115, p. 11-15.

${ }^{21}$ Directive (EU) 2019/904 of the European Parliament and of the Council of 5 June 2019 on the reduction of the impact of certain plastic products on the environment. OJ L 155, 12.6.2019, p. 1-19.

22 Directive 2000/53/EC of the European Parliament and of the Council of 18 September 2000 on end-of-life vehicles. OJ L 269, p. 34-43.

${ }^{23}$ Directive 2005/64/EC of the European Parliament and of the Council of 26 October 2005 on the type-approval of motor vehicles with regard to their reusability, recyclability and recoverability and amending Council Directive 70/156/EEC. OJ L 310, p. 10-27.

${ }^{24}$ Directive 2006/66/EC of the European Parliament and of the Council of 6 September 2006 on batteries and accumulators and waste batteries and accumulators. OJ L 266, p. 1-14.

${ }^{25}$ Directive 2012/19/EU of the European Parliament and of the Council of 4 July 2012 on waste electrical and electronic equipment. OJ L 197, p. 38-71.

${ }^{26}$ Directive 2011/65/EU of the European Parliament and of the Council of 8 June 2011 on the restriction of the use of certain hazardous substances in electrical and electronic equipment. OJ L 174, p. 88-110.

${ }^{27}$ Council Directive 86/278/EEC of 12 June 1986 on the protection of the environment, and in particular of the soil, when sewage sludge is used in agriculture. OJ L 181, p. 6-12.

${ }^{28}$ Directive 2006/21/EC of the European Parliament and of the Council of 15 March 2006 on the management of waste from extractive industries. OJ L 102, p. 15-34.

${ }^{29}$ Directive 2000/59/EC of the European Parliament and of the Council of 27 November 2000 on port reception facilities for ship-generated waste and cargo residues. OJ L 332, p. 81-90.

30 The Basel Convention on the Control of Transboundary Movements of Hazardous Wastes and Their Disposal (1999). Council Decision 93/98/EEC of 1 February 1993 on the conclusion, on behalf of the Community, of the Convention on the control of transboundary movements of hazardous wastes and their disposal (Basel Convention). OJ L 39, p. 1-2.

${ }^{31}$ Council Regulation (Euratom) No 1493/93 of 8 June 1993 on shipments of radioactive substances between Member States. OJ L 148, p. 1-7. Council Directive 2006/117/Euratom of 20 November 2006 on the supervision and control of shipments of radioactive waste and spent fuel. OJ L 337, p. 21-32.

32 Council Directive 2011/70/Euratom of 19 July 2011 establishing a Community framework for the responsible and safe management of spent fuel and radioactive waste. OJ L 199, p. 48-56. 


\section{Best practice: Summaries and guidelines}

The official website of European Union law is EUR-Lex. It is published in 24 official languages of the EU and, besides the Official Journal (OJ), also includes databases of other relevant sources of law. Users can access it free of charge and register for a free account, which offers extra features. EUR-Lex also provides summaries of EU legislation, ${ }^{33}$ short, easy-to-understand explanations of the main legal acts, intended for a general, non-specialist audience. The summaries are grouped into 32 policy fields, and each links to the full, official version of the act.

According to the European Commission's website, ${ }^{34}$ proper implementation, application and enforcement of EU waste legislation are among the key priorities of EU environmental policy. Since the date of application of the Directive 2008/98/EC on waste, many questions regarding its interpretation and application have been raised by national authorities and stakeholders. Guidance documents are intended to assist both national authorities and economic operators with the proper implementation of the legislation.

Examples of freely available guidelines (also cited in this publication):

- Guidance on the Interpretation of Key Provisions of Directive 2008/98/EC on Waste

- Preparing a Waste Management Plan: A Methodological Guidance Note

- Preparing a Waste Prevention Programme: Guidance Document

- Guidelines on the Preparation of Food Waste Prevention Programmes

Waste law has increasingly become a part of the broader policy framework for sustainable consumption and production and the so-called circular economy. This has led to an increasing focus on reuse and recovery and the design and composition of products to minimise waste generation and make the substances that do become waste easier to turn into new products. In 2014 the Commission presented a strategy called Towards a circular economy: A zero waste programme for Europe. However, the new Commission withdrew the proposal, and in late 2015 has adopted The Circular Economy Package, consisting of an action plan called Closing the loop - An EU action plan for the Circular Economy and six partly revised proposals for amending waste-related directives. ${ }^{35}$ In March 2020, the Commission adopted another updated version called A new Circular Economy Action Plan for a Cleaner and More Competitive Europe. ${ }^{36}$ It is supposed to provide a future-oriented agenda for achieving a cleaner and more competitive Europe in co-creation with economic actors, consumers, citizens and civil society organisations. It aims at accelerating the transformational change required by the European Green Deal while building on circular economy actions implemented since 2015. This plan will ensure that the regulatory framework is streamlined and made fit for a sustainable future, that the new opportunities from the transition are maximised, while minimising burdens on people and businesses. $^{37}$

In the new Action Plan, the Commission also proposed to establish a global alliance to identify knowledge and governance gaps to advance a global circular economy and to take forward partnership initiatives, including major economies. In February 2021, the Global Alliance on Circular Economy and Resource Efficiency (GACERE) was launched, bringing together governments and relevant networks and organisations with the aims to provide a global impetus

\footnotetext{
${ }^{33}$ EUR-Lex. Summaries of EU legislation. Available on-line at https://eur-lex.europa.eu/browse/summaries.html ${ }^{34}$ EUROPEAN COMMISSION. Waste Framework Directive. Available on-line at https://ec.europa.eu/environment/waste/framework/guidance.htm.

${ }^{35}$ LANGLET, D., MAHMOUDI, S. EU Environmental Law and Policy. Oxford University Press. 2016, p. 284.

${ }^{36}$ EUROPEAN COMMISSION. Communication from the Commission to the European Parliament, the Council, the European Economic and Social Committee and the Committee of the Regions: A new Circular Economy Action Plan - For a cleaner and more competitive Europe, Brussels, 11.3.2020 COM(2020) 98 final. ${ }^{37}$ Ibid., p. 2-3.
} 
for initiatives related to the circular economy transition, resource efficiency, and sustainable consumption and production, building on efforts being deployed internationally. GACERE has been established by the European Commission, on behalf of the EU, and by the United Nations Environment Programme (UNEP), in coordination with the United Nations Industrial Development Organization (UNIDO). ${ }^{38}$

The above mentioned European Green Dea $\boldsymbol{P}^{9}$ has been adopted in 2019 as the EU's response to the challenges related to climate change, introducing the strategy for a climate-neutral, resource-efficient and competitive economy. Following that, the Commission has published the new Circular Economy Action Plan, ${ }^{40}$ which confirms the linkage between the idea of the circular economy and the Green Deal and provides a set of measures for its implementation. And, according to the Plan, ${ }^{41}$ to support a global shift to a circular economy, the Commission will lead efforts at the international level to reach a global agreement on plastics, ${ }^{42}$ and promote the uptake of the EU's circular economy approach on plastics, propose a Global Circular Economy Alliance to identify knowledge and governance gaps in advancing a global circular economy and take forward partnership initiative, build a stronger partnership with Africa to maximise the benefits of the green transition and the circular economy, ensure that Free Trade Agreements reflect the enhanced objectives of the circular economy, continue promoting the circular economy in the accession process with the Western Balkans, and in the context of bilateral, regional and multilateral policy dialogues, fora and environmental agreements, or step up outreach activities, including through the European Green Deal diplomacy and the Circular Economy missions.

\subsubsection{Institutional framework}

It is also necessary to briefly describe the institutional framework of the European Union and its activities in relation to waste policy and law. Generally, according to the Treaty on European Union, ${ }^{43}$ the Union have an institutional framework which shall aim to promote its values, advance its objectives, serve its interests, those of its citizens and those of the Member States, and ensure the consistency, effectiveness and continuity of its policies and actions.

Main Union's institutions are the European Parliament, the European Council, the Council, the European Commission, the Court of Justice of the European Union, the European Central Bank and the Court of Auditors. The European Parliament shall, jointly with the Council, exercise legislative and budgetary functions. It shall exercise functions of political control and consultation as laid down in the Treaties. The European Council shall provide the Union with the necessary impetus for its development and shall define the general political directions and priorities thereof. The Commission shall promote the general interest of the Union and take

\footnotetext{
${ }^{38}$ EUROPEAN COMMISSION. Global Alliance on Circular Economy and Resource Efficiency (GACERE). Available on-line at https://ec.europa.eu/environment/international_issues/gacere.html. The EU and the following countries have joined GACERE in February 2021: Canada, Chile, Colombia, Japan, Kenya, New Zealand, Nigeria, Norway, Peru, Rwanda and South Africa.

${ }^{39}$ EUROPEAN COMMISSION. Communication from the Commission to the European Parliament, the Council, the European Economic and Social Committee and the Committee of the Regions. The European Green Deal, $\operatorname{COM}(2019) 640$ final.

${ }^{40}$ EUROPEAN COMMISSION. Communication from the Commission to the European Parliament, the Council, the European Economic and Social Committee and the Committee of the Regions. A new Circular Economy Action Plan For a cleaner and more competitive Europe, COM(2020) 98 final.

${ }^{41}$ Ibid., p. 18.

42 The total global production of plastics grew from around 1.5 million tonnes in 1950 to 311 million tonnes in 2014, plastics consumption rate in Europe is around 60 million tonnes per year; PLASTICS RECYCLERS EUROPE. 20 Years Later \& The Way Forward: Making more from plastics waste, Strategy Paper 2016, p. 7. 43 Articles 13-17 TEU.
} 
appropriate initiatives to that end. It shall ensure the application of the Treaties, and measures adopted by the institutions pursuant to them. It shall oversee the application of Union law under the control of the Court of Justice of the European Union.

Regarding the environment, the Treaty on Functioning of the European Union states, ${ }^{44}$ that the European Parliament and the Council, acting in accordance with the ordinary legislative procedure and after consulting the Economic and Social Committee and the Committee of the Regions, shall decide what action is to be taken by the Union in order to achieve the objectives of the environmental policy. In some cases, the Council shall act unanimously in accordance with a special legislative procedure; that is the case of adoption, e.g. provisions primarily of a fiscal nature or measures affecting town and country planning, quantitative management of water resources or affecting, directly or indirectly, the availability of those resources, but also land use, with the exception of waste management, or measures significantly affecting a Member State's choice between different energy sources and the general structure of its energy supply.

An important role is also played by other institutions, first of all, the European Environmental Agency (EEA), which provides sound, independent information on the environment for those involved in developing, adopting, implementing and evaluating environmental policy, and also the general public because it gathers data and produces assessments on a wide range of topics related to the environment. ${ }^{45}$ It also includes a topic called 'Resource efficiency and waste'. ${ }^{46}$ Within the EEA are established several consortia of organisations with expertise in specific environmental areas, contracted by the EEA to support the implementation of the EEA work programmes, called European Topic Centres (ETCs). Among them is also the European Topic Centre on Waste and Materials in a Green Economy (ETC/WMGE) whose role is to inform decision-makers and the public by presenting reliable and comparable data and information on waste management and prevention, green economy, material resource efficiency and the transition to a circular economy in Europe.$^{47}$ Another organisation dealing with the collection, analysis, and publication of data is Eurostat. Regarding waste management, it produces regular statistics on waste generation and treatment for the whole economy and specific waste streams. ${ }^{48}$

Institutions and authorities of the EU and the individual Member States are in various forms of contact and exchange of information and data. One of the official and formal ways, important for evaluating means of implementation of a particular policy is reporting. Member states have various reporting obligations concerning the implementation of waste legislation. The two main types of reports include reporting on targets and implementation reports. Reporting on targets includes annual or bi-annual reports on achieving various targets for waste collection, re-use, recycling and recovery. These reports cover waste streams such as packaging waste, waste electrical and electronic equipment, end-of-life vehicles, waste batteries and accumulators, household and similar waste, and construction and demolition waste. Implementation reports are three-annual reports, based on questionnaires that cover the main aspects of the implementation of waste legislation.

Based on information reported by the Member States, the Commission prepares its own Implementation Report summarizing the state of implementation of waste legislation in the

\footnotetext{
44 Article 192 TFEU.

${ }^{45}$ EUROPEAN ENVIRONMENTAL AGENCY. About us. Available online at https://www.eea.europa.eu/about-us.

${ }^{46}$ EUROPEAN ENVIRONMENTAL AGENCY. Resource efficiency and waste. Available online at https://www.eea.europa.eu/themes/waste.

${ }^{47}$ EIONET PORTAL. Waste and Materials in a Green Economy. Available online at

https://www.eionet.europa.eu/etcs/etc-wmge.

48 EUROSTAT. Waste - Overview. Available on-line at https://ec.europa.eu/eurostat/web/waste.
} 
EU. ${ }^{49}$ The most recent Implementation Report was published in September 2018 and includes the Early Warning Report for EU waste legislation, ${ }^{50}$ highlighting where Member States risk not meeting the EU waste targets. In parallel, the Commission took action in 2018 to remedy structural flaws in the waste legislation of the Member States, such as the ongoing presence of illegal or substandard landfills or the absence of waste management plans. ${ }^{51}$

\section{Best practice: Permitting and inspection}

In 2011, within the project "Services to support Member States' enforcement actions and inspections concerning the application of EU waste legislation", DG Environment of the European Commission launched a study aiming at gathering from the EU Member States examples of best practice in permitting and inspection related to the enforcement of certain pieces of waste legislation, and preparing, on this basis, a set of recommendations and guidance documents.

The study focused on the Directive on waste, Directive on landfill, Directive on electrical and electronic equipment and the Directive on the restriction of the use of certain hazardous substances in electrical and electronic equipment.

The study resulted in preparing a set of guidance and best practice documents which are presented on the Commission's website. ${ }^{52}$

When it comes to practical implementation of the EU law from the Union's perspective, the leading role is played by the Commission and the Court of Justice. To inform about its role of the Guardian of the Treaty, the European Commission publishes annual reports on monitoring the application of EU law. ${ }^{53}$ According to the latest, the Commission referred ten environmental cases to the Court under Article 258 TFEU during 2018, two of them on waste management. In case C-250/18, the Commission objects failure of Croatia to ensure adequate protection of human health and the environment from industrial waste in Biljane Donje. And in case C$642 / 18$ is considered a failure of Spain to adopt waste management plans and revise these plans according to the Waste Framework Directive. ${ }^{54}$

The Commission's report also provides information ${ }^{55}$ that, following actions that the Commission has brought in previous years, during 2018, the Court gave three rulings related to waste management, specifically to the Landfill Directive. Romania (C-301/17) has breached the Directive by failing to close down 68 landfills that had not received authorisation to continue operating. Slovenia (C-506/17) has failed to fulfil its obligations under Directive by the fact that 20 landfills which had not been granted authorisation to continue operation have not been closed and rehabilitated, and another landfill has not been brought into compliance with the requirements of the Directive. And Slovakia (C-626/16) has failed to comply with an earlier

\footnotetext{
${ }^{49}$ EUROPEAN COMMISSION. Reporting on implementation of waste legislation. Available on-line at https://ec.europa.eu/environment/waste/reporting/index.htm.

${ }^{50}$ EUROPEAN COMMISSION. Report from the Commission to the European Parliament, the Council, the European Economic and Social Committee and the Committee of the Regions on the implementation of EU waste legislation, including the early warning report for the Member States at risk of missing the 2020 preparation for reuse/recycling target on municipal waste. Brussels, 24.9.2018 COM(2018) 656 final.

${ }^{51}$ EUROPEAN COMMISSION. Monitoring the Application of European Union Law, 2018 Annual Report, p. 4.

52 EUROPEAN COMMISSION. Waste Framework Directive: Inspections and enforcement. Available online at https://ec.europa.eu/environment/waste/framework/inspections.htm.

${ }^{53}$ EUROPEAN COMMISSION. Annual Reports on Monitoring the Application of EU Law. Available online at https://ec.europa.eu/info/publications/annual-reports-monitoring-application-eu-law_en.

${ }^{54}$ EUROPEAN COMMISSION. Monitoring the application of European Union Law, 2018 Annual Report, Part II: Policy Areas. p. 31.

${ }_{55}^{5}$ EUROPEAN COMMISSION. Monitoring the application of European Union Law, 2018 Annual Report, Part II: Policy Areas. p. 34.
} 
Court judgment (C-331/11) that it had failed to fulfil its obligations under the Landfill Directive by authorising the operation of the Žilina-Považský Chlmec landfill site without a siteconditioning plan and in the absence of a definite decision on its continued operation based on an approved site-conditioning plan. The Court ordered Slovakia to pay a lump sum of EUR 1 000000 and a daily penalty of EUR 5000 until full compliance is achieved. ${ }^{56}$

\subsection{Management of municipal waste}

\subsubsection{Waste, municipal waste and their management}

To provide a clear and generally accepted definition of waste seems to be a challenge. As explained by Sands ${ }^{57}$ human activity generates waste in solid, liquid or gaseous form, and these wastes have tended to be categorised by regulatory instruments at the national and international level according to two characteristics: their source (municipal or industrial, including agricultural and mining); and/or their hazardous qualities (non-hazardous, hazardous and ultra-hazardous). Within these categorisations, international legal instruments adopt a range of different definitions. That raised the difficulty of defining waste, a matter which continues to cause legal difficulties today. International legal regulation of waste began in the early 1970s with the adoption of two treaties that prohibited the disposal at sea of certain types of waste, the 1972 London Convention and 1976 Barcelona Dumping Protocol. ${ }^{58}$ According to both these documents, wastes or other matter means material and substance of any kind, form or description. Obviously, such a broad and general definition is not self-standing and needs to be used within the context of the particular rules set by the individual legal instrument.

It was in 1975 when the European Economic Community (EEC) adopted its first Directive on waste. $^{59}$ According to Article 1 , waste means any substance or object which the holder disposes of or is required to dispose of pursuant to the provisions of national law in force. As also mentioned by Sands, ${ }^{60}$ this definition caused practical problems because it allowed many substances to be excluded if the holder treated the substances other than by disposal. In 1990, the European Court of Justice (ECJ) broadened the definition of waste under the 1975 Directive by interpreting Article 1 as not excluding substances and objects which are capable of economic re-utilisation. ${ }^{61}$ The following year the definition was further amended to mean any substance or object ... which the holder discards or intent or is required to discard and falls into one of the categories set out in Annex I to the amended Directive. ${ }^{62}$ However, as explained by Langlet and Mahmoudi, ${ }^{63}$ since one of these categories was any materials, substances or products which are not contained in the above categories, this requirement did not actually add to the definition of waste and was later removed from the article defining waste. In 2006 was adopted codified

\footnotetext{
56 See also Court press release No 99/18. Available on-line at https://curia.europa.eu/jcms/upload/docs/application/pdf/2018-07/cp180099en.pdf.

${ }^{57}$ SANDS, P. Principles of International Environmental Law. Cambridge University Press, 2003, p. 677.

${ }^{58}$ Convention on the Preservation of Marine Pollution by Dumping of Waste and Other Matter (London, 1972), Protocol for the Prevention of Pollution of the Mediterranean Sea by Dumping from Ships and Aircraft (Barcelona, 1976).

${ }^{59}$ Council Directive 75/442/EEC of 15 July 1975 on waste. OJ L 194, p. 39-41.

${ }^{60}$ SANDS, P. Principles of International Environmental Law. Cambridge University Press, 2003, p. 677-678.

${ }^{61}$ Joined cases C-206/88 and C-207/88, Vessaso and Zanetti.

${ }^{62}$ Council Directive 91/156/EEC of 18 March 1991 amending Directive 75/442/EEC on waste, OJ L 78, p. 32-37.

${ }^{63}$ LANGLET, D., MAHMOUDI, S. EU Environmental Law and Policy. Oxford University Press. 2016, p. 285.
} 
version of the Directive on waste ${ }^{64}$ incorporating the amendments from 1991 as well as later ones. Only two years later, it was replaced by the current Directive on waste. ${ }^{65}$

But even then, the question was not solved, and to a certain extent, it remains still unsolved. According to Kingston et al., ${ }^{66}$ the concept of waste is the subject of perennial debate by both academics and judges. That is not surprising, as the subjective interpretation of waste differs from its legal and scientific meaning. An individual considers an object or substance waste based on its specific properties or its characteristics and does not care about the potential value that the waste may have. The method of treatment or use of the substance would also signify for an individual that an object should be considered as waste. Moreover, individuals are not concerned with the lifecycle of waste once they discard it, nor do they appreciate the subtle nuances between various stages of the waste hierarchy. Still, the definition of waste takes into account the intention of the holder of waste to discard the waste. As a result of economic and technological development, we face different types of waste that require prevention to avoid adverse environmental or human health impacts. Yet, waste should not only be associated with environmental pollution but should be recognized as a valuable resource.

When it comes to municipal waste, there is no generally binding legal definition set by international law. According to Sands ${ }^{67}$ municipal waste generally includes that generated by households, shops, offices and other commercial units, and includes paper and cardboard, glass, plastics, metals, organic matters and putrescible materials. The generation of municipal wastes is closely related to the level of industrialisation and income: by the early 1990s, in industrialised countries, each person generated between 2.75 and $4 \mathrm{~kg}$ of waste per day, but in least-developed countries, each person generated on average only $0.5 \mathrm{~kg}$ per day. Rapid industrialisation has resulted in large increases in the generation of paper and plastic waste. ${ }^{68}$

The Organisation for Economic Co-operation and Development (OECD) ${ }^{69}$ defines municipal waste as waste collected and treated by or for municipalities. It covers waste from households, including bulky waste, similar waste from commerce and trade, office buildings, institutions and small businesses, as well as yard and garden waste, street sweepings, the contents of litter containers, and market cleansing waste if managed as household waste. The definition excludes waste from municipal sewage networks and treatment, as well as waste from construction and demolition activities. According to the OECD's recent environmental report, ${ }^{70}$ a person living in the OECD area generates on average $520 \mathrm{~kg}$ of municipal waste per year; this is $30 \mathrm{~kg}$ less than in 2000 , but still $20 \mathrm{~kg}$ more than in 1990 .

In Article 2 of the Directive on the landfill of waste, ${ }^{71}$ which has been adopted in 1999, municipal waste was defined as waste from households and other waste which, because of its nature or composition, is similar to waste from household. This provision has been replaced by a more complex definition set in Article 3 of the Directive on waste, as amended in 2018. ${ }^{72} \mathrm{It}$ states that municipal waste means (a) mixed waste and separately collected waste from households, including paper and cardboard, glass, metals, plastics, bio- waste, wood, textiles,

${ }^{64}$ Directive 2006/12/EC of the European Parliament and of the Council of 5 April 2006 on waste. OJ L 114, p. 921.

${ }^{65}$ Directive 2008/98/EC of the European Parliament and of the Council of 19 November 2008 on waste and repealing certain Directives. OJ L 312, p. 3-30.

${ }^{66}$ KINGSTON, S., HEYVAERT, V., CAVOŠKI, A. European Environmental Law. Cambridge University Press, 2017, p. 489, 498-499.

${ }^{67}$ SANDS, P. Principles of International Environmental Law. Cambridge University Press, 2003, p. 678.

${ }^{68}$ Ibid., referring to UNEP. Environmental Data Report, 1991, p. 334 and Table 8.2.

${ }^{69}$ OECD. Data: Municipal waste. Available on-line at https://data.oecd.org/waste/municipal-waste.htm.

70 OECD. Environment at a Glance 2020, Paris: OECD Publishing, p. 11.

${ }^{71}$ Council Directive 1999/31/EC of 26 April 1999 on the landfill of waste. OJ L 182, p. 1-19.

${ }^{72}$ Directive (EU) 2018/851 of the European Parliament and of the Council of 30 May 2018 amending Directive 2008/98/EC on waste. OJ L 150, p. 109-140. 
packaging, waste electrical and electronic equipment, waste batteries and accumulators, and bulky waste, including mattresses and furniture; (b) mixed waste and separately collected waste from other sources, where such waste is similar in nature and composition to waste from households.

On the other hand, municipal waste does not include waste from production, agriculture, forestry, fishing, septic tanks and sewage network and treatment, including sewage sludge, endof-life vehicles or construction and demolition waste. And finally, the Directive states that the definition is without prejudice to the allocation of responsibilities for waste management between public and private actors. ${ }^{73}$

According to the statistical office of the EU, Eurostat, ${ }^{74}$ municipal waste consists of waste collected by or on behalf of municipal authorities and disposed of through waste management systems. The municipal waste consists mainly of waste generated by households, although it also includes similar waste from sources such as shops, offices and public institutions. According to recent statistics, ${ }^{75}$ municipal waste accounts for only about $10 \%$ of total waste generated when compared with the data reported according to the Waste Statistics Regulation. ${ }^{76}$ However, it has a very high political profile because of its complex character, composition, distribution among many sources of waste, and its link to consumption patterns. For 2019, municipal waste generation totals vary considerably, ranging from $280 \mathrm{~kg}$ per capita in Romania to $844 \mathrm{~kg}$ per capita in Denmark. The variations reflect differences in consumption patterns and economic wealth and depend on how municipal waste is collected and managed. There are differences between countries regarding the degree to which waste from commerce, trade and administration is collected and managed with waste from households.

These examples and data show that municipal waste is not always a clearly defined term, but it is considered a waste stream. As explained by Bourguignon, ${ }^{77}$ waste streams are flows of specific waste, from its source through to recovery, recycling or disposal. Together they make up the overall waste treated in the European Union. Waste streams can be divided into two broad types: streams made of materials (such as metals or plastics) or streams made of certain products (such as electronic waste or end-of-life vehicles) which require specific treatment and ultimately feed into materials-related streams. In this sense, it is then used in official documents and literature. The Communication on the EU Action Plan on Circular Economy ${ }^{78}$ may serve as an example, stating that the legislative proposals on waste, adopted together with this action plan, includes long-term targets to reduce landfilling and to increase preparation for reuse and recycling of key waste streams such as municipal waste and packaging waste.

Waste management is defined in Article 3 of the Directive on Waste ${ }^{79}$ as the collection, transport, recovery and disposal of waste, including the supervision of such operations and the aftercare of disposal sites, including actions taken as a dealer or broker.

\footnotetext{
${ }^{73}$ Ibid.

${ }^{74}$ EUROSTAT. Glossary: Municipal waste. Available online at https://ec.europa.eu/eurostat/statisticsexplained/index.php?title=Glossary:Municipal_waste.

${ }^{75}$ EUROSTAT. Municipal waste statistics. Available on-line at https://ec.europa.eu/eurostat/statisticsexplained/index.php/Municipal_waste_statistics.

${ }^{76}$ Regulation (EC) No 2150/2002 of the European Parliament and of the Council of 25 November 2002 on waste statistics. OJ L 332, p. 1-36.

${ }_{77}$ BOURGUIGNON, D. Understanding waste streams: Treatment of specific waste. European Parliamentary Research Service, 2015, p. 1.

${ }^{78}$ EUROPEAN COMMISSION. Communication from the Commission to the European Parliament, the Council, the European Economic and Social Committee and the Committee of the Regions: Closing the loop - An EU action plan for the Circular Economy, Brussels, 2.12.2015 COM(2015) 614 final.

${ }^{79}$ Directive 2008/98/EC of the European Parliament and of the Council of 19 November 2008 on waste and repealing certain Directives. OJ L 312, p. 3-30.
} 
In a broader sense, the subject matter and scope of the general legal framework of waste management in the EU is defined by Article 1 of the Directive. It lays down measures to protect the environment and human health by preventing or reducing the adverse impacts of the generation and management of waste, reducing overall impacts of resource use, and improving the efficiency of such use. In Article 13, the Directive also sets the general requirement that waste management shall be carried out without endangering human health or harming the environment. In particular, it shall be without risk to water, air, soil, plants, or animals; without causing a nuisance through noise or odours; and without adversely affecting the countryside or places of special interest.

As noted by Langlet and Mahmoudi, ${ }^{80}$ the Court of Justice has found an almost identical provision in an earlier directive to be neither unconditional nor sufficiently precise to confer rights on which individuals may rely against the State, that is, lacking the direct effect. ${ }^{81}$ In fact, it is quite hard to conceive how waste management, that is collection, transport, recovery and disposal of waste, could be carried out without even a risk to water and soil and without causing a nuisance.

Waste management is based on the waste hierarchy. Article 4 of the Directive on Waste states that the following waste hierarchy shall apply as a priority order in waste prevention and management legislation and policy: a) prevention, b) preparing for re-use, c) recycling, d) other recovery, e.g. energy recovery and e) disposal. The hierarchy is reflecting a general approach under EU waste management law. It sets out five possible ways of dealing with waste and prioritises these measures. This prioritisation lays down a priority order of what constitutes the best overall environmental option in waste legislation and policy. According to guidance on the interpretation of the Directive, ${ }^{82}$ the waste hierarchy is the cornerstone of European waste policy and legislation. Its primary purpose is to minimise adverse environmental effects from waste and to increase and optimise resource efficiency in waste management and policy.

Figure 1: Waste bierarchy ${ }^{83}$

\section{Waste hierarchy}

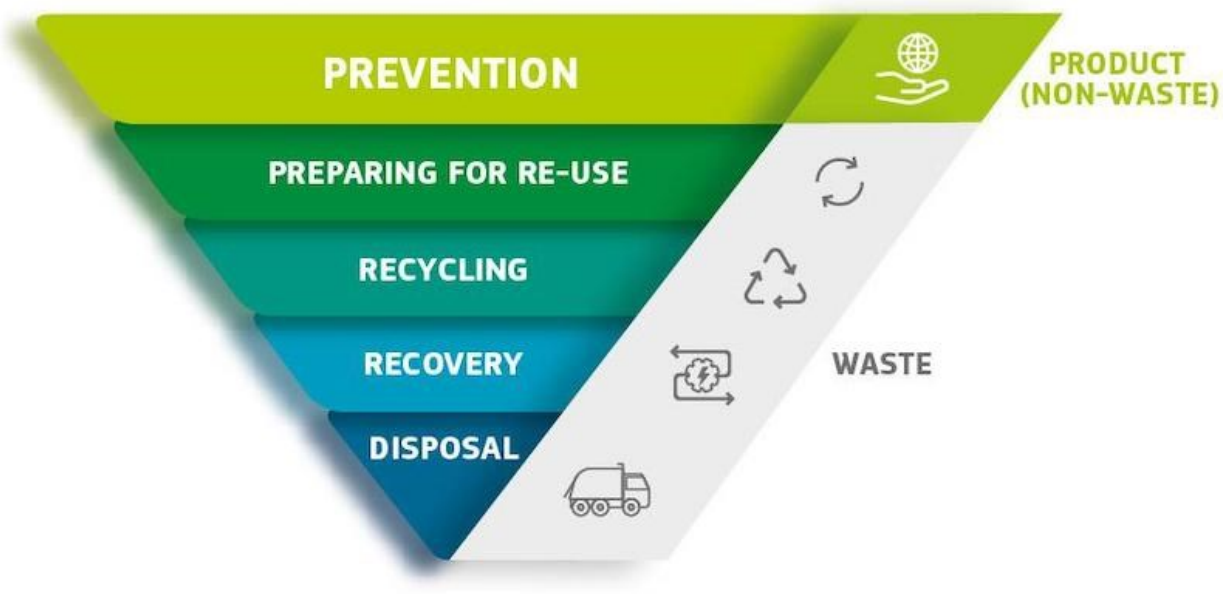

\footnotetext{
${ }^{80}$ LANGLET, D., MAHMOUDI, S. EU Environmental Law and Policy. Oxford University Press. 2016, p. 287.

${ }^{81}$ Case C-236/92, Comitato di Coordinamento per la Difesa della Cava and others vs Regione Lombardia and others.

82 EUROPEAN COMMISSION. Guidance on the interpretation of key provisions of Directive 2008/98/EC on waste. Brussels, 2012, p. 48.

83 EUROPEAN COMMISSION. Waste Framework Directive. Available online at https://ec.europa.eu/environment/topics/waste-and-recycling/waste-framework-directive_en.
} 
A crucial aspect of any national, regional or local policy on waste management is considered waste management planning. The drawing up of waste management plans is required by Article 28 of the Directive on waste. It states that the waste management plans shall set out an analysis of the current waste management situation in the geographical entity concerned, as well as the measures to be taken to improve environmentally sound preparing for re-use, recycling, recovery and disposal of waste and an evaluation of how the plan will support the implementation of the objectives and provisions of this Directive.

Establishing a plan allows taking stock of the existing situation, defining the objectives that need to be met, formulating appropriate strategies, and identifying the necessary implementation means. Article 28 of the Directive lists the mandatory elements of a waste management plan, such as the type, quantity and source of waste generated within the territory, existing waste collection schemes and major disposal and recovery installations, an assessment of the need for new collection schemes, or general waste management policies, including planned waste management technologies and methods.

Basic administrative rules concerning waste management planning include requirements that waste management plans need to be evaluated at least every sixth year and revised as appropriate, relevant stakeholders and authorities and the general public must have an opportunity to participate in the elaboration of the plans and have access to them once elaborated, and the plans shall be placed on a publicly available website. In order to assist national, regional and local competent authorities in preparing waste management plans in line with the requirements of the Directive, the Commission has published a methodological guideline ${ }^{84}$ that promotes more coherent and appropriate planning practices. ${ }^{85}$

\subsubsection{Phases of management of municipal waste}

Prevention is regarded as the preferable solution by the waste hierarchy. Although, technically, it is not a waste-management measure because it concerns substances or objects before they become waste. Prevention is defined by Article 3 of the Directive on Waste as measures, taken before a substance, material or product has become waste, that reduce the quantity of waste, including through the re-use of products or the extension of the life span of products, the adverse impacts of the generated waste on the environment and human health, or the content of harmful substances in materials and products.

As explained by the European Commission, ${ }^{86}$ reducing the amount of waste generated at the source and reducing the hazardous content of that waste is regarded as the highest priority according to the waste hierarchy established in Article 4 of the Directive. Waste prevention is closely linked with improving manufacturing methods and influencing consumers to demand greener products and less packaging. In order to move up the waste hierarchy, Article 29 of the Directive requires that the Member States shall establish Waste Prevention Programmes. To support Member States when developing these Programmes, a guidance document ${ }^{87}$ has been prepared. It clarifies the main concepts related to waste prevention, suggesting a framework to develop the Programmes and providing best practices and examples of national and regional programmes employing a compelling mix of measures. It also includes a list of further resources on waste prevention theory and practice.

\footnotetext{
${ }^{84}$ EUROPEAN COMMISSION. Preparing a Waste Management Plan: A Methodological Guidance Note. Brussels, 2012.

${ }^{85}$ EUROPEAN COMMISSION. Waste Management Planning. Available online at

https://ec.europa.eu/environment/waste/plans/index.htm.

${ }^{86}$ EUROPEAN COMMISSION. Waste Prevention. Available online at

https://ec.europa.eu/environment/waste/prevention/index.htm.

${ }^{87}$ EUROPEAN COMMISSION. Preparing a Waste Prevention Programme: Guidance document. October 2012.
} 


\section{Best practice: Prevention}

According to the European Commission, ${ }^{88}$ effective strategies to promote public awareness of waste prevention and reduce the generation of specific types of waste are already operating in the EU Member States and abroad. On the cited website, the Commission presents factsheets on the selected waste prevention best practices. The factsheets summarise each initiative, describing the regional background, policy context and targeted waste stream. The objectives, means and results of each initiative are explained, accompanied by resources for further information.

According to the Directive on Waste (Articles 3, 11 and 16), collection means gathering of waste, including the preliminary sorting and preliminary storage of waste for the purposes of transport to a waste treatment facility. The Directive also defines separate collection as the collection where a waste stream is kept separately by type and nature so as to facilitate a specific treatment. For re-use and recycling, Member States shall take measures to promote high-quality recycling and set up separate collections of waste where technically, environmentally and economically practicable and appropriate to meet the necessary quality standards for the relevant recycling sectors. To stimulate principles of self-sufficiency and proximity, Member States shall take appropriate measures, in cooperation with the other Member States where this is necessary or advisable, to establish an integrated and adequate network of waste disposal installations and of installations for the recovery of mixed municipal waste collected from private households, including where such collection also covers such waste from other producers, taking into account best available techniques. Also, according to the Court of Justice, Member State authorities are empowered to regulate or organise the management of waste, especially in mixed municipal waste, in such a way that it is treated in the nearest appropriate facility. ${ }^{89} \mathrm{But}$, on the other hand, in order to protect their networks, the Member States may under certain circumstances limit incoming shipments of waste as well as outgoing shipment of waste on environmental grounds. ${ }^{90}$

According to the Commission's Report on the implementation of EU waste legislation, ${ }^{91}$ among suggested actions, if implemented swiftly by national and local authorities, that may significantly reduce the risk of the re-use and recycling targets not being met, belong the need to cascade national recycling targets down to the municipal level with responsibility for waste collection systems, development of guidance with local and regional authorities for municipalities in the form of a minimum service standard for separate collection, the introduction of mandatory requirements to sort bio-waste, and ensure that planned or existing treatment infrastructure matches the collection systems, or the introduction of measures to encourage households to sort waste, including higher collection frequency for separated streams as compared with that for mixed waste.

\footnotetext{
${ }^{88}$ EUROPEAN COMMISSION. Waste Prevention: Best Practices. Available online at https://ec.europa.eu/environment/waste/prevention/practices.htm.

${ }^{89}$ Case C-292/12, Ragn-Sells AS vs Sillamäe Linnavalitsus.

${ }^{90}$ LANGLET, D., MAHMOUDI, S. EU Environmental Law and Policy. Oxford University Press. 2016, p. 292.

${ }^{91}$ EUROPEAN COMMISSION. Report from the Commission to the European Parliament, the Council, the European Economic and Social Committee and the Committee of the Regions on the implementation of EU waste legislation, including the early warning report for the Member States at risk of missing the 2020 preparation for reuse/recycling target on municipal waste. Brussels, 24.9.2018 COM(2018) 656 final, p. 2-3.
} 


\section{Best practice: Collection}

As described in the publication Best Environmental Management Practice for the Waste Management Sector, ${ }^{92}$ it is considered a best practice to design and implement a waste collection strategy. Such strategy may include main features (e.g. several separately collected waste fractions), targets (e.g. share of separately collected waste out of the total waste collected, impurity rates of the separately collected fractions, revenues from recyclables), characteristics of the collection area (e.g. population density and main housing types), current environmental attitudes and perceptions of residents, any other specific condition affecting waste collection (e.g. the relevant presence of tourists/commuters, specific economic activities, climate).

The main goal of a waste collection strategy is to collect, in a timely and economical manner, as much correctly source-separated waste as possible, to ease the subsequent waste sorting/treatment to maximise recycling. In many cases, these objectives can be pursued by setting up the following: a frequent door-to-door separate collection of food waste (e.g. weekly or more often depending on the season and climate); a less frequent collection of mixed waste (e.g. every two weeks); a door-to-door collection of recyclables (e.g. paper, cardboard, cans, plastics, glass), individually source-separated where public acceptability allows, otherwise co-mingled and sorted at a material recovery facility; glass, followed by paper and cardboard, is more often more effectively collected separately; a convenient network of civic amenity sites that accept all waste fractions not collected door-to-door or in street containers from households, including hazardous waste and biowaste.

During spring 2020, as a reaction to the global pandemic of coronavirus, the European Commission has published two guidelines focused on specific aspects of management of waste. One of them is providing recommendations related to the shipment of waste, such as ensuring smooth cross-border transport, electronic exchange of documents and information, or facilitating waste shipment procedures. ${ }^{93}$ The other focuses on particular aspects of municipal waste management, waste from healthcare facilities, health and safety of waste management operators and provides information about support from EU funds, state aid and an exchange of information and awareness-raising. ${ }^{94}$

\section{Best practice: Waste collection during the coronavirus pandemic}

Regarding municipal waste, the guideline ${ }^{95}$ states that in view of Article 13 of the Directive on waste, waste collection practices can be adapted in the context of the coronavirus crisis with the objective of protecting public health. Any such changes should comply with the EU law on waste, be necessary and proportionate to protect human health by limiting them to areas and time periods strictly necessary to respond to the risk identified based on the latest scientific advice and strive to maintain the overall objective of separate collection and recycling in line with the waste hierarchy. As for specific recommendations, it is mentioned, e.g., that paper tissues and face masks used by the patient should be immediately put in the waste bag that was placed in the patient's room. These waste bags can be collected and placed in a clean general garbage bag; the closed patient waste bags can be put directly in the unsorted garbage. No special collection activity or other disposal method is necessary.

\footnotetext{
92 DRI, M., CANFORA, P., ANTONOPOUlOS, I. S., GAUDILLAT, P., Best Environmental Management Practice for the Waste Management Sector, JRC Science for Policy Report. Publications Office of the European Union, Luxembourg, 2018, p. 310.

${ }^{93}$ EUROPEAN COMMISSION. Shipments of waste in the EU in the context of the coronavirus crisis. Available on-line at https://ec.europa.eu/environment/waste/shipments/pdf/waste_shipment_and_COVID19.pdf.

${ }^{94}$ EUROPEAN COMMISSION. Waste management in the context of the coronavirus crisis. Available on-line at https://ec.europa.eu/info/files/waste-management-context-coronavirus-crisis_en.

95 Ibid., p. 2-3.
} 
The Regulation on the shipment of waste ${ }^{96}$ establishes procedures and control regimes for the shipment of waste, depending on the origin, destination and route of the shipment, the type of waste shipped and the type of treatment to be applied to the waste at its destination. The Regulation distinguishes between the general term transport, which is defined as the carriage of waste by road, rail, air, sea or inland waterways, and the specific term shipment, which means the transport of waste destined for recovery or disposal which is planned or takes place between a country and another country; or between a country and overseas countries and territories or other areas, under that country's protection; or between a country and any land area which is not part of any country under international law; or between a country and the Antarctic; or from one country through any of the areas referred to above; or within a country through any of the areas referred to above and which originates in and ends in the same country; or from a geographic area not under the jurisdiction of any country, to a country. ${ }^{97}$ And further, illegal shipment is also defined.

Transport of waste, or eventually the shipment, are very complex issues, and the Regulation also reflects that. ${ }^{98}$ Article 1, which sets the scope of the Regulation, states that it shall apply to shipments of waste between the Member States, within the EU or with transit through third countries, imported into the Union from third countries, exported from the Union to third countries, and in transit through the Union, on the way from and to third countries. On the other hand, from the scope of this Regulation shall be excluded waste which is subject to the requirements of the MARPOL Convention, ${ }^{99}$ or other binding international instruments, ${ }^{100}$ waste generated onboard vehicles, trains, aeroplanes and ships, until such waste is offloaded to be recovered or disposed of, shipments of radioactive waste, ${ }^{101}$ or shipments of waste from the Antarctic into the Union. ${ }^{102}$ According to Article 3 of the Regulation, which sets rules for an overall procedural framework of shipments within the Union with or without transit through third countries, shipments of mixed municipal waste collected from private households, including where such collection also covers such waste from other producers, to recovery or disposal facilities shall, in accordance with this Regulation, be subject to the same provisions as shipments of waste destined for disposal.

\section{Best practice: Transport}

Waste has to be often transported considerable distances from the point of disposal to reuse or treatment locations. From a life-cycle perspective, transportation of waste may give rise to significant greenhouse gases $(\mathrm{GHG})$ and $\mathrm{NO}_{\mathrm{x}}$ emissions, and also result into significant fossil resource depletion, traffic, noise and odours. Municipal waste collection from residential areas can lead to significant emissions owing to inefficient start-stop driving of large waste collection trucks.

\footnotetext{
${ }^{96}$ Article 1 of the Regulation (EC) No 1013/2006 of the European Parliament and of the Council of 14 June 2006 on shipments of waste. OJ L 190, p. 1-98.

${ }^{97}$ Article 2 of the Regulation (EC) No 1013/2006 of the European Parliament and of the Council of 14 June 2006 on shipments of waste. OJ L 190, p. 1-98.

98 With 64 articles and 9 annexes, it is characterised as 'an extremely complicated piece of legislation'; see JANS, J. H., VEDDER, H. H. B. European Environmental Law: After Lisbon. Europa Law Publishing, 2012, p. 492

${ }^{99}$ International Convention for the Prevention of Pollution from Ships (1973) as modified by the Protocol of 1978 (MARPOL 73/78)

${ }^{100}$ E.g. the Basel Convention on the Control of Transboundary Movements of Hazardous Wastes and Their Disposal (1999), adopted by the Union by the Council Decision 93/98/EEC of 1 February 1993 on the conclusion, on behalf of the Community, of the Convention on the control of transboundary movements of hazardous wastes and their disposal (Basel Convention). OJ L 39, p. 1-2.

${ }^{101}$ Council Regulation (Euratom) No 1493/93 of 8 June 1993 on shipments of radioactive substances between Member States. OJ L 148, p. 1-7. Council Directive 2006/117/Euratom of 20 November 2006 on the supervision and control of shipments of radioactive waste and spent fuel. OJ L 337, p. 21-32.

102 Covered by the Protocol on Environmental Protection to the Antarctic Treaty (Madrid, 1991).
} 
As a consequence, separate collection of waste fractions may lead to higher transport burdens compared with non-separated collection. ${ }^{103}$

It is a best practice to optimise the logistics of waste collection by: installing, where appropriate, an alternative collection system to road transport, such as a pneumatic system in urban areas; using Computerised Vehicle Routing and Scheduling (CVRS) technology to optimise collection rounds; exploring collaboration opportunities with neighbouring waste management organisations; benchmarking fuel/energy consumption and/or $\mathrm{CO}_{2}$ emissions; incorporating one or more environmental metrics, such as cumulative energy demand and/or $\mathrm{CO}_{2}$ emissions, into network design and route optimisation algorithms; installing telematics equipment in collection vehicles for real-time route optimisation based on GPS and training drivers in eco-driving techniques. ${ }^{104}$

After the collection and transport, there are two options for how waste can be treated: recovery and disposal. As explained by the guidance on the interpretation of the Directive on waste, ${ }^{105}$ on the one hand, recovery and the opposite term disposal (negatively defined as operations which are not recovery) together comprise waste treatment. Any waste treatment can only be either a recovery operation or a disposal operation; the Court of Justice of the EU (CJEU) has explicitly stated $^{106}$ that no operation can be classified as disposal and recovery at the same time.

Recovery is defined by Article 3 of the Directive on Waste as any operation the principal result of which is waste serving a useful purpose by replacing other materials which would have otherwise used to fulfil a particular function, or waste being prepared to fulfil that function, in the plant or in the wider economy. It is explained by the guidance ${ }^{107}$ in a way that the substitution achieved, which is crucial for waste recovery, can take place not just in the plant where the waste is being treated but also in the wider economy. That aims to facilitate the classification of waste incinerators. It should be noted that, according to the definition, these provisions apply not only where material is substituting other materials, but also to processes preparing a waste material in such a way that it no longer involves waste-related risks and is ready to be used as a raw material in other processes.

A non-exhaustive list of recovery operations is set out by the Annex II of the Directive. This definition of recovery has been newly introduced into the Directive, taking as its starting point CJEU case law, where the approach of substitution as a precondition for recovery was developed. ${ }^{108}$ According to Article 10 of the Directive, Member States shall take the necessary measures to ensure that waste undergoes recovery operations, according to Articles 4 (Waste hierarchy) and 13 (Protection of human health and the environment). Where necessary to comply with these requirements and to facilitate or improve recovery, waste shall be collected separately if technically, environmentally and economically practicable and shall not be mixed with other waste or other material with different properties.

Recovery is divided into three sub-categories: preparing for re-use, recycling, and other recovery.

The first sub-category of recovery is preparing for re-use, which is an important phase for identifying if the material is considered waste. As defined by Article 3 of the Directive on waste,

${ }^{103}$ DRI, M., CANFORA, P., ANTONOPOULOS, I. S., GAUDILLAT, P., Best Environmental Management Practice for the Waste Management Sector, JRC Science for Policy Report. Publications Office of the European Union, Luxembourg, 2018, p. 74.

104 Ibid., p. 361.

105 EUROPEAN COMMISSION. Guidance on the interpretation of key provisions of Directive 2008/98/EC on waste. Brussels, 2012, p. 30.

106 Case C-6/00, Abfall Service AG (ASA) vs Bundesminister für Umwelt, Jugend und Familie.

${ }^{107}$ EUROPEAN COMMISSION. Guidance on the interpretation of key provisions of Directive 2008/98/EC on waste. Brussels, 2012, p. 31.

108 Ibid., referring to rulings Case C-6/00, Abfall Service AG (ASA) vs Bundesminister für Umwelt, Jugend und Familie and C-228/00, Commission vs Germany. 
it means checking, cleaning or repairing recovery operations, by which products or components of products that have become waste are prepared so that they can be re-used without any other pre-processing.

But it has to be taken into consideration that the self-standing term re-use is defined by Article 3 of the Directive as any operation by which products or components that are not waste are used again for the same purpose for which they were conceived. It means, strictly speaking, that reuse is a way of waste prevention. For example, suppose a person takes over a material, e.g., a piece of clothing, directly from the current owner with the intention of re-using (even if some repairing is necessary) it for the same purpose. In that case, this comprises evidence that the material is not a waste. The key difference between 're-use' and 'preparing for re-use' is that in the former case, the material or object has not become a waste, whereas in the case of 'preparing for re-use', the material in question has become waste in the meaning of the waste definition. Examples for preparing for re-use comprise repairing bicycles, furniture, or electrical or electronic equipment which their owners previously discarded. ${ }^{109}$

Another option of recovery (but a self-standing level of the waste hierarchy) is recycling. According to Article 3 of the Directive, it means any recovery operation by which waste materials are reprocessed into products, materials or substances, whether for the original or other purposes. It includes the reprocessing of organic material but does not include energy recovery and the reprocessing into materials that are to be used as fuels or for backfilling operations. As noted by Kingston et al., ${ }^{110}$ the Directive clearly indicates the EU's ambition to become a true recycling society, but the targets set out in the Directive do not reflect this ambition and are considered to be very disappointing.

It includes the reprocessing of organic material but does not include energy recovery and the reprocessing into materials that are to be used as fuels or for backfilling operations. The common idea behind recycling is that waste material is processed to alter its physicochemical properties allowing it to be used again for the same or other applications. Recycling includes any physical, chemical or biological treatment leading to a material that is no longer a waste. Under the waste hierarchy, preference is given to recycling ahead of those other forms of recovery. It is also an explicit goal of the Directive on waste (see Recital 28) that the EU should become more of a recycling society, seeking to avoid waste generation and to use waste as a resource. ${ }^{111}$

Other forms of recovery are not mentioned among definitions in Article 3 of the Directive on waste. Therefore, other recovery is any operation meeting the definition for 'recovery' under the Directive but failing to comply with the specific requirements for preparation for re-use or recycling. Examples of other recovery operations are incineration or co-incineration, where the principal use of the waste is as a fuel or other means to generate energy. It is a waste management operation with energy recovery. That contrasts with the incineration of waste without energy recovery, classified as a disposal operation. ${ }^{112}$ As mentioned by Kingston et al., ${ }^{113}$ incineration of waste is a relatively new waste treatment operation which still raises concerns about its impact on the environment and human health, and involves significant costs. The receptiveness of this waste treatment in some Member States is often constrained by the opposition of the wider public to waste incineration installations in the locality. Until recently,

${ }^{109}$ EUROPEAN COMMISSION. Guidance on the interpretation of key provisions of Directive 2008/98/EC on waste. Brussels, 2012, p. 30.

${ }^{110}$ KINGSTON, S., HEYVAERT, V., ČAVOŠKI, A. European Environmental Law. Cambridge University Press, 2017, p. 496.

${ }^{111}$ EUROPEAN COMMISSION. Guidance on the interpretation of key provisions of Directive 2008/98/EC on waste. Brussels, 2012, p. 32.

112 Ibid., p. 33-34.

113 KINGSTON, S., HEYVAERT, V., ČAVOŠKI, A. European Environmental Law. Cambridge University Press, 2017, p. 510. 
the use of this waste treatment option was primarily regulated by the Waste incineration directive. ${ }^{114}$ However, as a part of the review of EU acquis, it has been included into the Directive on industrial emissions. ${ }^{115}$ The Member States must put in place a permitting system, including a provision in cases of a substantial change of operation of a waste incineration plant, and are responsible for monitoring inspection and enforcement. ${ }^{116}$

\section{Best practice: Recovery}

An example of best practice in waste recovery is the processing of mixed plastic packaging waste, maximising recycling yields for high-quality output. The term 'mixed plastic packaging waste' covers all plastic packaging waste sourced from the domestic waste stream and includes rigid and flexible plastic items of various polymer types and colours that are typically generated by households. It usually excludes non-packaging items, even though in some EU countries some non-packaging items are starting to be admitted in the recyclables collection bin. When this collected waste enters material recovery facilities, plastic bottles and containers of the different polymer types can be efficiently separated, but the rest of this flow largely remains as a residual component that is commonly sent to final disposal or energy recovery. The major challenge in producing valuable recyclate (i.e. materials resulting from the processing of plastic waste, such as pellets, granules and flakes) from mixed plastic packaging waste is that most plastic types are inherently immiscible at the molecular level and have different processing requirements. Furthermore, when plastic is contaminated, or of a limited quantity or with a varied composition, recycling is more difficult. Therefore, to achieve efficient mechanical recycling, mixed plastic packaging waste should be processed as far as possible into single clean types. ${ }^{117}$

It is considered a best environmental management practice to process separately collected mixed plastic packaging waste in individual material streams that can be transformed into valuable, highquality secondary raw materials and recycled products. The process encompasses the following steps: sorting flexible plastic packaging waste from the rigid items (film sorting) by using film grabbers, air drum or ballistic separators followed by a manual quality assurance step; sorting plastic bottles and other rigid items by polymer and colour with optical sorting systems; reducing sorted film and residual rigid items (as separate flows) in flakes by using granulators; cleaning flaked plastic packaging using friction cleaning (dry or wet grinding systems); separating and washing flaked plastic packaging by polymer and colour by using optical sorting systems or density separation technologies; extruding flaked material into pellets. ${ }^{118}$

Finally, according to Article 3 of the Directive on waste, disposal means any operation which is not recovery even where the operation has as a secondary consequence the reclamation of substances or energy. It follows from this definition that any waste treatment operation which does not meet the criteria of the recovery definition is by default considered to be disposal. The wording 'even where the operation has as a secondary consequence the reclamation of substances or energy' reflects, by contrast, the idea that any recovery operation must meet the

\footnotetext{
114 Directive 2000/76/EC of the European Parliament and of the Council of 4 December 2000 on the incineration of waste. OJ L 332, p. 91-111.

115 Directive 2010/75/EU of the European Parliament and of the Council of 24 November 2010 on industrial emissions (integrated pollution prevention and control). OJ L 334, p. 17-119.

116 KINGSTON, S., HEYVAERT, V., ČAVOŠKI, A. European Environmental Law. Cambridge University Press, 2017, p. 511.

117 DRI, M., CANFORA, P., ANTONOPOULOS, I. S., GAUDILLAT, P., Best Environmental Management Practice for the Waste Management Sector, JRC Science for Policy Report. Publications Office of the European Union, Luxembourg, 2018, p. 426.

118 Ibid., p. 425.
} 
criterion of 'the principal result' being 'waste serving a useful purpose' by substituting material which would otherwise have been used for that purpose. ${ }^{119}$

Besides the general framework set by the Directive on waste, disposal is further regulated by the Directive on landfill of waste. ${ }^{120}$ Its overall objective is, as defined in Article 1, by way of stringent operational and technical requirements on the waste and landfills, to provide for measures, procedures and guidance to prevent or reduce as far as possible negative effects on the environment, in particular the pollution of surface water, groundwater, soil and air, and on the global environment, including the greenhouse effect, as well as any resulting risk to human health, from landfilling of waste, during the whole life-cycle of the landfill. The Directive was adopted in 1999 with the purpose of achieving several ambitious goals. The reduction of adverse environmental impacts on the environment and on human health undoubtedly is seen as its primary objective. Attainment of this objective demonstrates the interconnectedness of waste policy with other environmental sectors, since the disposal at landfills significantly impacts other EU environmental policies, such as protection of water and soil and climate change. The Directive also plays an important role in encouraging the waste management hierarchy and diversion of waste from landfills. In this regard, the Directive sets out targets for the progressive reduction of biodegradable municipal waste disposed at landfills. Besides its environmental agenda, the EU attempts to harmonize technical and methodological standards in waste policy across the EU by setting standards for the disposal of waste at landfills. ${ }^{121}$

The Directive applies to all landfills, defined as waste disposal sites for depositing of waste onto or into the land. Landfills are divided into three classes: landfills for hazardous waste, landfills for non-hazardous waste and landfills for inert waste. On the other hand, the Directive does not apply to, e.g., the spreading on the soil of sludges, or the deposit of unpolluted soil or nonhazardous inert waste resulting from prospecting and extraction, treatment, and storage of mineral resources as well as from the operation of quarries. The Directive also sets up a system of operating permits for landfill sites. The Member States must ensure that existing landfill sites may not continue to operate unless they comply with the provisions of the Directive. ${ }^{122}$

\section{Best practice: Disposal}

The Strategy for Sustainable Construction, established jointly by industry and the UK Government in 2008, aimed to increase profitability through materials efficiency, reduce construction, demolition and excavation waste by $50 \%$ in 2012 on a 2008 baseline, and deliver a radical change in the construction industry sustainability. That formed a basis for the 'Halving Waste to Landfill' initiative, supporting the Zero Waste Scotland Policy and the Northern Ireland Waste Strategy. The 'Halving Waste to Landfill' commitment was a voluntary agreement undertaken by construction companies to adopt good practices in waste reduction, recycling and the use of recycled and recovered materials. It was organised by the Waste \& Resources Action Programme (WRAP). ${ }^{123}$ WRAP provided several tools to help construction companies meet their commitment, including waste assessment tools, construction logistics plans, site waste management plans, green procurement guides, or cost-benefit analysis and case studies. One hundred major companies have signed the commitment in the six months since the initiative was launched. As a result of the strong response

\footnotetext{
${ }^{119}$ EUROPEAN COMMISSION. Guidance on the interpretation of key provisions of Directive 2008/98/EC on waste. Brussels, 2012, p. 34.

${ }^{120}$ Council Directive 1999/31/EC of 26 April 1999 on the landfill of waste. OJ L 182, p. 1-19.

${ }^{121}$ KINGSTON, S., HEYVAERT, V., ČAVOŠKI, A. European Environmental Law. Cambridge University Press, 2017, p. 508-509.

122 EUROPEAN COMMISSION. Landfill of waste. Available online at http:/ / ec.europa.eu/environment/waste/landfill/index.htm.

${ }^{123}$ For more details, see WRAP. Available online at https://wrap.org.uk.
} 
to the commitment, WRAP launched a cross-sector agreement to allow supply chain producers and clients to make their commitments supporting the overall waste reduction target. ${ }^{124}$

\subsubsection{Treatment of specific components of municipal waste}

It has been already mentioned above, with reference to Bourguignon, that municipal waste is considered as a waste stream, meaning a flow of specific type of waste from its source through to recovery, recycling, or disposal. Generally, municipal waste consists of waste collected by or on behalf of municipal authorities and disposed of through waste management systems.

According to statistics, in 2019 were generated $502 \mathrm{~kg}$ of municipal waste per capita in the EU, ranging from $280 \mathrm{~kg}$ in Romania to $844 \mathrm{~kg}$ in Denmark. ${ }^{125}$ The following figure shows overall trends in treatment of municipal waste in previous 25 years.

Figure 2: Municipal Waste Treatment in EU 27, 1995-2019126

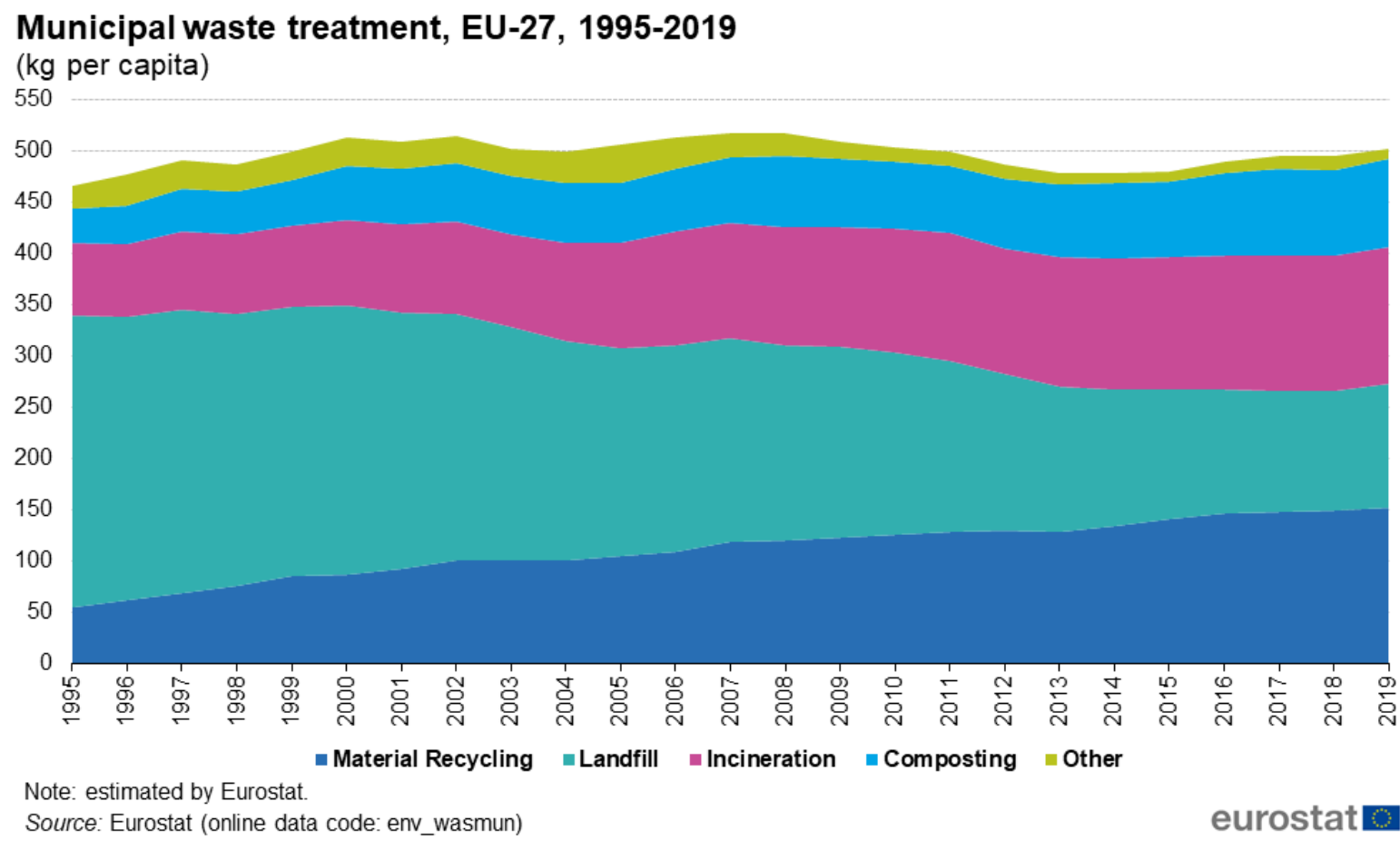

Article 3 of the Directive on waste defines municipal waste as (a) mixed waste and separately collected waste from households, including paper and cardboard, glass, metals, plastics, bio-waste, wood, textiles, packaging, waste electrical and electronic equipment, waste batteries and accumulators, and bulky waste, including mattresses and furniture; (b) mixed waste and separately collected waste from other sources, where such waste is similar in nature and composition to waste from households. Therefore, while dealing with municipal waste, it is necessary to keep in mind that it contains mainly waste generated by households, but it may also

\footnotetext{
${ }^{124}$ EUROPEAN COMMISSION. Waste prevention: Best practices. Available online at https://ec.europa.eu/environment/waste/prevention/practices.htm.

${ }^{125}$ EUROSTAT. Municipal waste statistics. Available on-line at https://ec.europa.eu/eurostat/statisticsexplained/index.php/Municipal_waste_statistics.

126 Ibid.
} 
include, depending on legal regime in individual Member State, similar waste from other sources such as shops, offices and public institutions.

The Directive further states that municipal waste does not include waste from production, agriculture, forestry, fishing, septic tanks, and sewage network and treatment, including sewage sludge, end-of-life vehicles, or construction and demolition waste.

A significant part of municipal waste is generated from packaging. According to the New Circular Economy Action Plan, the amount of materials used for packaging is growing continuously and in 2017 packaging waste in Europe reached a record, $173 \mathrm{~kg}$ per inhabitant, the highest level ever. ${ }^{127}$ Beside the general legal framework set by the Directive on waste, since 1994 there are specific rules set by the Directive on packaging. ${ }^{128}$ According to its Article 1, this Directive aims to harmonize national measures concerning the management of packaging and packaging waste in order, on the one hand, to prevent any impact thereof on the environment of all Member States as well as of third countries or to reduce such impact, thus providing a high level of environmental protection, and, on the other hand, to ensure the functioning of the internal market and to avoid obstacles to trade and distortion and restriction of competition.

Packaging means, according to Article 3 of the Directive, all products made of any materials of any nature to be used for the containment, protection, handling, delivery, and presentation of goods, from raw materials to processed goods, from the producer to the user or the consumer. The Directive further distinguish three categories of packaging. Firstly, the sales packaging or primary packaging, i. e. packaging conceived so as to constitute a sales unit to the final user or consumer at the point of purchase. Second, the grouped packaging or secondary packaging, i. e. packaging conceived so as to constitute at the point of purchase a grouping of a certain number of sales units, whether the latter is sold as such to the final user or consumer or whether it serves only as a means to replenish the shelves at the point of sale; it can be removed from the product without affecting its characteristics. Third, the transport packaging or tertiary packaging, i. e. packaging conceived so as to facilitate handling and transport of a number of sales units or grouped packaging in order to prevent physical handling and transport damage; transport packaging does not include road, rail, ship, and air containers.

The scope of the Directive on packaging is defined broadly by its Article 2, stating that it covers all packaging placed on the market in the Union and all packaging waste, whether it is used or released at industrial, commercial, office, shop, service, household or any other level, regardless of the material used. Following that, the Directive requires Member States to prevent the generation of packaging waste and to minimise the environmental impact of packaging (Article 4) and to encourage the increase in the share of reusable packaging, without compromising food hygiene or the safety of consumers; this may include deposit-return schemes, setting of qualitative or quantitative targets, use of economic incentives, or setting up of a minimum percentage of reusable packaging placed on the market every year for each packaging stream (Articles 5 and 7). Detailed attention is paid in Article 6 to recovery and recycling; specific recycling targets are set as follows.

${ }^{127}$ EUROPEAN COMMISSION. Communication from the Commission to the European Parliament, the Council, the European Economic and Social Committee and the Committee of the Regions: A new Circular Economy Action Plan - For a cleaner and more competitive Europe, Brussels, 11.3.2020 COM(2020) 98 final, p. 8.

${ }^{128}$ European Parliament and Council Directive 94/62/EC of 20 December 1994 on packaging and packaging waste. OJ L 365, p. 10-23. 


\begin{tabular}{llll} 
& Current targets (\%) & By 2025 (\%) & By 2030 (\%) \\
\hline All packaging & 55 & 65 & 70 \\
\hline Plastic & 25 & 50 & 55 \\
\hline Wood & 15 & 25 & 30 \\
\hline Ferrous metals & 50 (incl. Al) & 70 & 80 \\
\hline Aluminium & - & 50 & 60 \\
\hline Glass & 60 & 70 & 75 \\
\hline Paper and cardboard & 60 & 75 & 85 \\
\hline
\end{tabular}

According to the New Circular Economy Action Plan, ${ }^{130}$ in order to ensure that all packaging on the EU market is reusable or recyclable in an economically viable way by 2030 , the Commission will review Directive on packaging to reinforce the mandatory essential requirements for packaging to be allowed on the EU market. It also plans other measures, focusing on reduction of (over)packaging and packaging waste, design for reuse and recyclability of packaging, in particular where alternative reusable products or systems are possible or consumer goods can be handled safely without packaging, or consideration of reduction of the complexity of packaging materials, including the number of materials and polymers used.

\section{Best practice: Packaging waste}

When light packaging waste, i. e. packaging made of plastics, composites, aluminium and steel, sometimes also including fibres (paper and cardboard) is collected together (co-mingled), it is best environmental management practice to implement advanced sorting of the co-mingled packaging waste in materials recovery facilities (MRF).

A typical state-of-the-art plant has five main technical sections: feeding and preconditioning (this includes opening bags and feeding a constant flow of input material), pre-sorting (this involves removing unsuitable items), sorting (this includes several steps, e. g. separating fibre from containers, sorting fibre, sorting metal containers by using magnets or X-ray, first sorting of plastic containers by polymer), refining (this consists of additional sorting steps, such as further sorting of polymers by type and colour in order for the material output quality to meet market requirements) and product handling (this section consists of the baling processes and product storage as bales, loose material or in containers; product handling can also include loading operations for further downstream processes).

In principle, there are no barriers to building and operating a packaging waste sorting plant. However, careful planning (especially considering the collection schemes in place, the plant capacity and the availability of markets for the sorted materials) is required as part of an integrated waste management concept. An important factor that needs to be determined is the optimal plant

${ }^{129}$ EUROPEAN COMMISSION. Packaging waste. Available online at https://ec.europa.eu/environment/topics/waste-and-recycling/packaging-waste_en.

${ }^{130}$ EUROPEAN COMMISSION. Communication from the Commission to the European Parliament, the Council, the European Economic and Social Committee and the Committee of the Regions: A new Circular Economy Action Plan - For a cleaner and more competitive Europe, Brussels, 11.3.2020 COM(2020) 98 final, p. 8-9. 
Although they have only been used for a century, plastics have already become a symbol of human activity and presence, a symbol of pollution, environmental deterioration, and degradation. In 2018, the European Strategy for Plastics in a Circular Economy has been adopted, stating that there is an urgent need to tackle the environmental problems that today cast a long shadow over the production, use, and consumption of plastics. Being more specific, the Strategy mentions that over the past 50 years, the role and importance of plastics in our economy have consistently grown. Global plastics production has increased 20 times since the 1960s, reaching 322 million tonnes in 2015. It is expected to double again over the next 20 years. Around 26 million tonnes of plastic waste are generated in Europe every year, and less than 30\% of such waste is collected for recycling. Of this amount, a significant share leaves the EU to be treated in third countries, where different environmental standards may apply. At the same time, landfilling and incineration rates of plastic waste remain high, $31 \%$ and $39 \%$, respectively, and while landfill has decreased over the past decade, incineration has grown. According to estimates, $95 \%$ of the value of plastic packaging material, i. e. between EUR 70 and 105 billion annually, is lost to the economy after a very short first-use cycle. Very large quantities of plastic waste leak into the environment from sources both on land and at sea, generating significant economic and environmental damage. Globally, 5 to 13 million tonnes of plastics, that is, 1,5 to $4 \%$ of global plastics production, end up in the oceans every year. It is estimated that plastic accounts for over $80 \%$ of marine litter. In the EU, 150 to 500 thousand tonnes of plastic waste enter the oceans every year. ${ }^{132}$

Following those facts, the Strategy describes $A$ vision for Europe's new plastics economy, including a smart, innovative and sustainable plastics industry, where design and production fully respect the needs for reuse, repair, and recycling, bring growth and jobs to Europe and help cut EU's greenhouse gas emissions and dependence on imported fossil fuels. And further providing a vision of Europe where citizens, government and industry support more sustainable and safer consumption and production patterns for plastics which provides a fertile ground for social innovation and entrepreneurship, creating a wealth of opportunities for all Europeans. ${ }^{133}$ These objectives are then specified, and potential steps and measures are described, among them improving the economics and quality of plastics recycling, curbing plastic waste and littering, driving investment and innovation towards circular solutions, or harnessing global action. Annex I of the Strategy provides more details and also includes a timeline for individual steps, while Annex II lists measures recommended to national authorities and industry.

Plastics are commonly used also as packaging. In 2015, the Directive on packaging was amended by the Directive on light-weight plastic bags. ${ }^{134}$ As explained in the Preamble, although plastic carrier bags constitute packaging within the meaning of the Directive on packaging, it does not contain specific measures on the consumption of such bags. In addition, the consumption levels of plastic carrier bags have resulted in high levels of littering and an inefficient use of resources, and have been expected to increase, if no action is taken. The littering of plastic carrier bags has resulted in environmental pollution and aggravates the widespread problem of litter in water bodies, threatening aquatic ecosystems worldwide. Therefore, the Directive on lightweight plastic

\footnotetext{
${ }^{131}$ DRI, M., CANFORA, P., ANTONOPOULOS, I. S., GAUDILLAT, P., Best Environmental Management Practice for the Waste Management Sector, JRC Science for Policy Report. Publications Office of the European Union, Luxembourg, 2018, p. 403.

132 Ibid., p. 2-3.

133 Ibid., p. 5.

134 Directive (EU) 2015/720 of the European Parliament and of the Council of 29 April 2015 amending Directive 94/62/EC as regards reducing the consumption of lightweight plastic carrier bags. OJ L 115, p. 11-15.
} 
bags obliged Member States to take measures to achieve a sustained reduction in the consumption of lightweight plastic carrier bags on their territory. Those measures may include the use of national reduction targets, maintaining or introducing economic instruments as well as marketing restrictions, provided that these restrictions are proportionate and non-discriminatory.

Further restrictions related to plastics have been adopted in 2019 by the Directive on single-use plastics. ${ }^{135}$ According to Article 2, the Directive applies to the single-use plastic products listed in the Annex, to products made from oxo-degradable plastic and to fishing gear containing plastic. ${ }^{136}$ The objectives of this Directive, specified in Article 1, are to prevent and reduce the impact of certain plastic products on the environment, in particular the aquatic environment, and on human health, as well as to promote the transition to a circular economy with innovative and sustainable business models, products and materials, thus also contributing to the efficient functioning of the internal market. According to its preamble, the Directive promotes circular approaches that give priority to sustainable and nontoxic re-usable products and re-use systems rather than to single-use products, aiming first and foremost to reduce the quantity of waste generated. By retaining the value of products and materials for as long as possible and generating less waste, the economy of the Union can become more competitive and more resilient, while reducing pressure on precious resources and the environment. And further, the preamble refers to obligations set by international conventions, namely the United Nations Convention on the Law of the Sea of 10 December 1982 (UNCLOS), the Convention on the Prevention of Marine Pollution by Dumping of Wastes and Other Matter (London Convention) and its 1996 Protocol (London Protocol), the International Convention for the Prevention of Pollution from Ships (MARPOL), and the Basel Convention on the Control of Transboundary Movements of Hazardous Wastes and their Disposal.

Figure 4: Ten Most Common Plastic Object Found on European Beaches 137

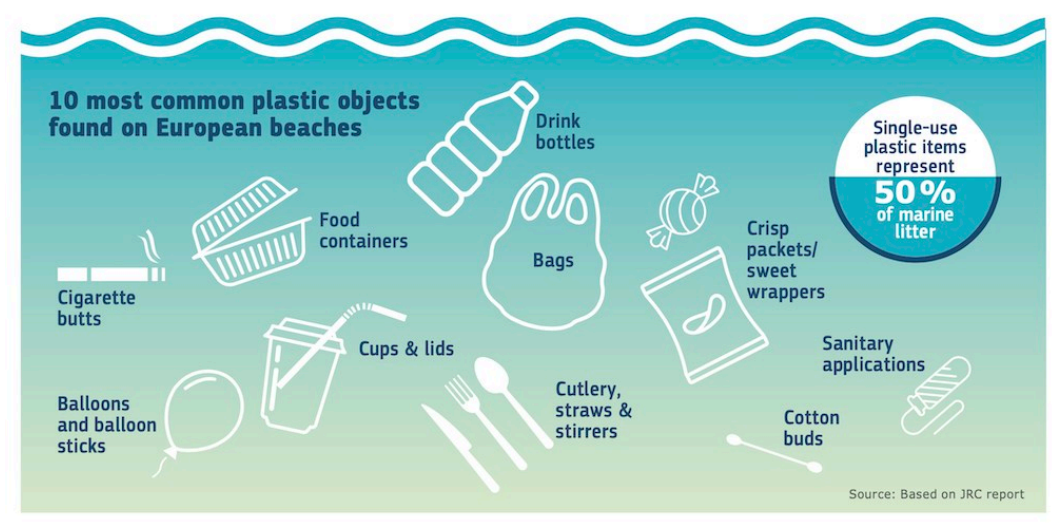

135 Directive (EU) 2019/904 of the European Parliament and of the Council of 5 June 2019 on the reduction of the impact of certain plastic products on the environment. OJ L 155, 12.6.2019, p. 1-19.

136 According to Article 3 of the Directive, single-use plastic product means a product that is made wholly or partly from plastic and that is not conceived, designed or placed on the market to accomplish, within its life span, multiple trips or rotations by being returned to a producer for refill or re-used for the same purpose for which it was conceived; oxo-degradable plastic means plastic materials that include additives which, through oxidation, lead to the fragmentation of the plastic material into micro-fragments or to chemical decomposition; and fishing gear means any item or piece of equipment that is used in fishing or aquaculture to target, capture or rear marine biological resources or that is floating on the sea surface, and is deployed with the objective of attracting and capturing or of rearing such marine biological resources.

${ }^{137}$ EUROPEAN COMMISSION. Changing the way we use plastics. Publications Office of the European Union, Luxembourg, 2018, p. 1. 
Another specific component of municipal waste is food waste. Generally speaking, food waste is an issue of importance to global food security and good environmental governance, directly linked with environmental (e. g., energy, climate change, water, availability of resources), economic (e. g., resource efficiency, price volatility, increasing costs, consumption, waste management, commodity markets) and social (e. g., health, equality) impacts. ${ }^{138}$ As stated by Inger Andersen, Executive Director of the United Nations Environment Programme (UNEP), in her foreword to annual UNEP Food Waste Index Report, ${ }^{139}$ if food loss and waste were a country, it would be the third biggest source of greenhouse gas emissions. Food waste also burdens waste management systems and exacerbates food insecurity, making it a major contributor to the three planetary crises of climate change, loss of nature and biodiversity, and pollution and waste. The report estimates that food waste from households, retail establishments, and the food service industry totals 931 million tonnes each year. Nearly 570 million tonnes of this waste occur at the household level. The report also reveals that the global average of $74 \mathrm{~kg}$ per capita of food wasted each year is remarkably similar from lower-middle income to high-income countries, suggesting that most countries have room to improve.

British consumers, for example, annually discard approximately 7 million tons of food, which is about a third of what they purchase, at a retail cost of around GBP 10,2 billion (USD 19,5 billion). This waste has a $\mathrm{CO}_{2}$ equivalent of 18 million tons, an amount equal to the annual emissions of one-fifth of Britain's total car fleet. As a percentage of their total food, developing countries do not fare much better in terms of wasting food. What varies is where in the food system losses occur. Whereas high-income regions incur considerable losses in the consumer end, most of the food lost in lower income regions occurs prior to its arrival into people's homes. For example, in India, roughly $30 \%$ of the country's fruits and vegetables and $30 \%$ of its grain are lost due to poor storage facilities. ${ }^{140}$ As indicated by the $\mathrm{CO}_{2}$ emissions equivalent mentioned above, there is also a direct link to climate change, and also to public health. Climate change - which is already affecting rainfall levels, temperatures, spread of pests, and soil and water chemistry - will also affect the food system. Climate change can increase food-related public health concerns by damaging food production, undermining food quality, and impeding food access. The consequences of climate change for the food system, and through that system for public health, are predictable yet complex. Complicating this story is the fact that food production itself is a significant contributor to climate change, and mitigation strategies are, perhaps falsely, viewed as a threat to food security. ${ }^{141}$

Estimates for the European Union show that every year 88 million tonnes of food waste are generated, which equates to 173 kilograms of food waste per person in the EU-28. The total amounts of food produced in EU around $865 \mathrm{~kg}$ per person, this would mean that in total we are wasting $20 \%$ of the food produced. The sectors contributing the most to food waste are households (47 million tonnes) and processing (17 million tonnes). These two sectors account for $72 \%$ of EU food waste, although there is considerable uncertainty around the estimate for the processing sector compared to all the other sectors. Of the remaining $28 \%$ of food waste, 11 million tonnes $(12 \%)$ come from food service, 9 million tonnes $(10 \%)$ come from primary production and 5 million tonnes $(5 \%)$ come from wholesale and retail. The costs associated with

\footnotetext{
${ }^{138}$ STENMARCK, A., JENSEN, C., QUESTED, T., MOATES, G. Estimates of European Food Waste Levels. Swedish Environmental Research Institute, 2016, p. 3. ${ }^{139}$ UNITED NATIONS ENVIRONMENT PROGRAMME. Food Waste Index Report 2021, Nairobi, p. 4. ${ }^{140}$ CAROLAN M. Food Systems. In CASTREE, N., HULME, M., PROCTOR, J. D. (eds.). Companion to Environmental Studies. Routledge, 2018, p. 197-198. 141 POLANS J. M. Food Systems. In BURGER, M., GUNDLACH, J. (eds.). Climate Change, Public Health, and the Law. Cambridge University Press, 2018, p. 266-267.
} 
food waste for EU-28 are estimated at around 143 billion euros. Two-thirds of the costs are associated with food waste from households (around 98 billion euros). ${ }^{142}$

According to the European Commission, ${ }^{143}$ the issue of tackling food waste is being taken very seriously. Reducing food waste has enormous potential for reducing the resources we use to produce the food we eat. Being more efficient will save food for human consumption, save money, and lower the environmental impact of food production and consumption. In 2020, the German Presidency to the Council of the European Union assessed progress made by Member States and the EU in their work to prevent and reduce food losses and food waste, as compared to the Council conclusions on food loss and waste adopted in $2016 .{ }^{144}$ The Council's assessment highlighted milestones achieved at EU level, as well as measures taken by Member States, such as the development of national strategies, adoption of legislative and non-legislative initiatives and consumer awareness campaigns. In 2020, as part of the European Green Deal, also the Farm to Fork Strategy ${ }^{145}$ has been adopted, which puts forward a series of actions to enable the transition to a sustainable EU food system that safeguards food security and ensures access to healthy diets sourced from a healthy planet. Reducing food loss and waste is an integral part of the strategy's Action Plan.

Another waste stream which concerns several aspects is biodegradable waste, or just biowaste. It is defined by Article 2 of the Directive on the landfill of waste as any waste that is capable of undergoing anaerobic or aerobic decomposition, such as food and garden waste, and paper and paperboard. As further explained by the Commission, ${ }^{146}$ in includes biodegradable garden and park waste, food and kitchen waste from households, restaurants, caterers and retail premises, and comparable waste from food processing plants. On the other hand, it does not include forestry or agricultural residues, manure, sewage sludge, or other biodegradable waste such as natural textiles or processed wood. One of the main environmental threat from biodegradable waste is the production of methane from decomposing in landfills. The Directive, adopted in 1999, has therefore obliged the Member States to reduce the amount of biodegradable municipal waste that they landfill to $35 \%$ of the 1995 levels by 2016. The Directive does not prescribe specific treatment options for the diverted waste. The most significant benefits of proper biowaste management, in addition to avoiding greenhouse gas emissions, would be the production of good quality compost and biogas that contribute to enhanced soil quality and resource efficiency, as well as a higher level of energy self-sufficiency.

Across the EU, between 118 and 138 million tonnes of bio-waste are generated annually, of which more than two thirds comes from municipal bio-waste, the reminder coming from the food and drink industry. In 2017 the recycling of municipal bio-waste across the EU-28 lay at 81 $\mathrm{kg}$ per capita or 41.5 million tonnes, however, there is a large variation among EU countries in separate collection and recycling of bio-waste per capita, ranging from $0-12 \mathrm{~kg}$ in Croatia to up to $97-182 \mathrm{~kg}$ in Germany, Austria or Italy. ${ }^{147}$

\footnotetext{
142 STENMARCK, A., JENSEN, C., QUESTED, T., MOATES, G. Estimates of European Food Waste Levels. Swedish Environmental Research Institute, 2016, p. 4-5.

143 EUROPEAN COMMISSION. EU actions against food waste. Available online at

https://ec.europa.eu/food/safety/food_waste/eu_actions_en.

${ }^{144}$ COUNCIL OF THE EUROPEAN UNION. Food losses and food waste. Assessment of progress made in implementing the Council conclusions adopted on 28 June 2016. Note 11665/20, Brussels, 9. 11. 2020.

${ }^{145}$ EUROPEAN COMMISSION. Communication from the Commission to the European Parliament, the Council, the European Economic and Social Committee and the Committee of the Regions: A Farm to Fork Strategy for a fair, healthy and environmentally friendly food system. Brussels, 20.5.2020 COM(2018) 381 final. 146 EUROPEAN COMMISSION. Biodegradable waste. Available online at https://ec.europa.eu/environment/topics/waste-and-recycling/biodegradable-waste_en. ${ }^{147}$ DUBOIS, M., SIMS, E., MOERMAN, T., WATSON, D., BAUER, B., BEL, J.-B., MEHLHART, G. Guidance for Separate Collection of Municipal Waste. Publications Office of the European Union, Luxembourg, 2020, p. 5455.
} 


\section{Best practice: Biodegradable waste}

The Guidance for Separate Collection of Municipal Waste ${ }^{148}$ provides several examples of good practice related to management of bio-waste:

- Freiburg in the state Baden-Württemberg in Germany has set targets for the separate collection of $60 \mathrm{~kg}$ kitchen waste per inhabitant and $90 \mathrm{~kg}$ green waste per inhabitant. The separate collection of bio-waste has been one of the key drivers to reduce the volumes of mixed waste collected to $90 \mathrm{~kg}$ per inhabitant and total recycling rates to $69 \%$.

- Covar 14, a public waste management company of in Piemonte Italy, has fostered home composting in the rural areas via awareness campaigns, via compost training courses and by giving a financial discount of $20 \%$ on waste taxes for families that joined the composting program.

- Freistadt in Austria set up a project where local farmers collect bio-waste from local towns, including both kitchen and canteen waste supplemented by wood, tree and bush cuttings. The collected fraction is composted in facilities for consumption at the farm or for sale. Key success factors were the legal framework (mandatory training and requirement of a contract with the municipality) and the involvement of local stakeholders. Reported data show a collection rate of $149 \mathrm{~kg} / \mathrm{cap} / \mathrm{y}$ while $80 \%$ of the compost produced is used in agriculture and $20 \%$ is sold to private customers.

- Afval Afhaal ("Waste Collection") introduced an innovative online platform in Amsterdam, the Netherlands, to connect restaurants and small enterprises that produce bio-waste with companies that can valorise the waste, e. g. the use of citrus peels for the production of soap. Via a user-friendly app street cleaner can pick up bio-waste from restaurants and deliver it to interested companies.

The amount of waste electrical and electronic equipment (known as WEEE or e-waste) generated every year in the EU is increasing rapidly. It is now one of the fastest growing waste streams which includes a large range of devices such as computers, fridges and mobile phones at the end of their life. This type of waste contains a complex mixture of materials, some of which are hazardous, and which can cause major environmental and health problems if the discarded devices are not managed properly. In addition, modern electronics contain rare and expensive resources, which can be recycled and re-used if waste is effectively managed. ${ }^{149}$

The legal framework is set by the Directive on electrical and electronic equipment, ${ }^{150}$ a very detailed and technical norm, covering various types of the electrical and electronic equipment (EEE) ${ }_{151}^{151}$ their classification and numerous exceptions from its scope. ${ }^{152}$ During the disposal, collection or treatment of WEEE, harmful hazardous substances such as lead, mercury or cadmium may be released, which can cause major environmental and health problems. To

\footnotetext{
148 Ibid., p. 56-62.

${ }^{149}$ EUROPEAN COMMISSION. Waste from Electrical and Electronic Equipment (WEEE). Available online at https://ec.europa.eu/environment/topics/waste-and-recycling/waste-electrical-and-electronic-equipment-weee_en. 150 Directive 2012/19/EU of the European Parliament and of the Council of 4 July 2012 on waste electrical and electronic equipment. OJ L 197, p. 38-71.

151 According to Article 3 of the Directive on electrical and electronic equipment, the EEE means equipment which is dependent on electric currents or electromagnetic fields in order to work properly and equipment for the generation, transfer and measurement of such currents and fields and designed for use with a voltage rating not exceeding 1000 volts for alternating current and 1 500 volts for direct current.

152 According to Article 2, this Directive shall not apply to equipment designed to be sent into space, large-scale stationary industrial tools, means of transport for persons or goods, excluding electric two-wheel vebicles which are not type-approved, non-road mobile machinery made available exclusively for professional use, equipment specifically designed solely for the purposes of research and development that is only made available on a business-to- business basis, or medical devices and in vitro diagnostic medical devices, where such devices are expected to be infective prior to end of life, and active implantable medical devices.
} 
address such challenges, further rules are provided by the Directive on the restriction of the use of certain hazardous substances in electrical and electronic equipment. ${ }^{153}$

According to Eurostat, ${ }^{154}$ the amount of EEE put on the market in the EU dropped from 7,9 million tonnes in 2010 to less than 7,3 million tonnes in 2013, corresponding to a fall of - $8 \%$ over this period. However, from this low, the amounts put on the market increased strongly, reaching 9 million tonnes in 2017, an increase of 24,1\%. From 2016 to 2017, the number of products put on the market grew by $7,4 \%$. The following figure shows both the collection level in the different countries and the progress made from 2008 to 2017. In 2017, the total amount of collected WEEE varied considerably across the EU Member States, ranging from 2,4 kg per inhabitant in Romania (2016 data) to 14,1 kg per inhabitant in Sweden. The variation in the collected amounts reflects differences in EEE consumption level between countries, as well as differences in the performance of their respective waste collection schemes.

\section{Waste electrical and electronic equipment (WEEE), total collected, 2008 and 2017 \\ (kg per inhabitant)}

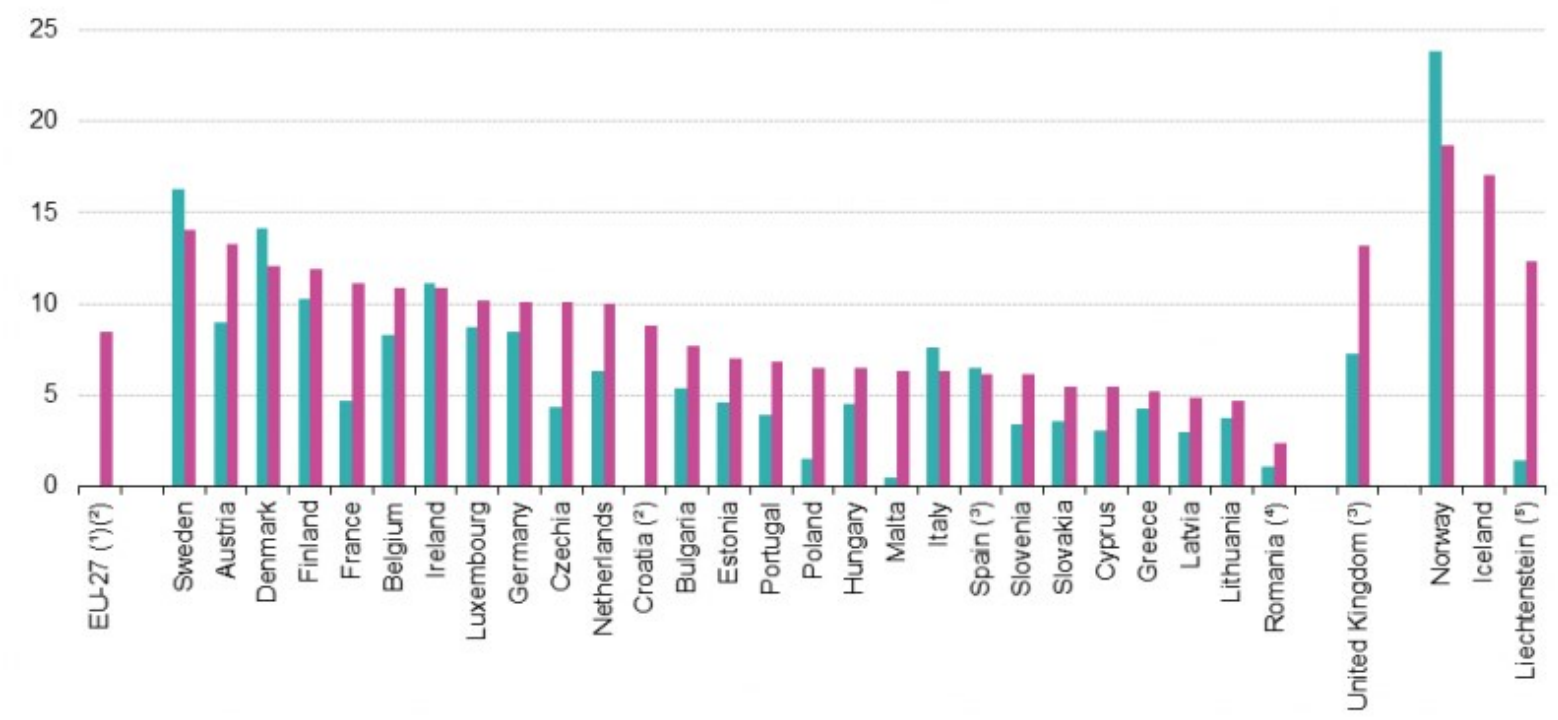

$=2008=2017$

Note: Countries are ranked based on 2017 data

(') Eurostat estimate.

( 2008 data not available

( 2008 data: Eurostat estimate.

(4) 2016 data instead of 2017

( ${ }^{5}$ Definition differs.

Source: Eurostat (online data code: env_waselee)

The Directive on electrical and electronic equipment aims to contribute to sustainable production and consumption by preventing the creation of WEEE as a first priority,

${ }^{153}$ Directive 2011/65/EU of the European Parliament and of the Council of 8 June 2011 on the restriction of the use of certain hazardous substances in electrical and electronic equipment. OJ L 174, p. 88-110.

${ }^{154}$ EUROSTAT. Waste statistics - electrical and electronic equipment. Available online at

https://ec.europa.eu/eurostat/statistics-explained/index.php?title=Waste_statistics_-

_electrical_and_electronic_equipment.

155 Ibid. 
contributing to the efficient use of resources and the retrieval of secondary raw materials through re-use, recycling and other forms of recovery and improving the environmental performance of everyone involved in the life cycle of EEE. To achieve these objectives, the Directive requires the separate collection and proper treatment of WEEE and sets targets for their collection as well as for their recovery and recycling, helps European countries fight illegal waste exports more effectively by making it harder for exporters to disguise illegal shipments of WEEE and reduces the administrative burden by calling for the harmonisation of national EEE registers and of the reporting format. ${ }^{156}$

\section{Best practice: Waste electrical and electronic equipment}

Final report of the WEEE Compliance Promotion Exercise ${ }^{157}$ provides numerous examples of good practice related to management of WEEE, such as:

- WasteServ in Malta launched a new website, which offers members of the public the opportunity to give away any unwanted items like electronics to extend the life of these items before they become waste.

- In Flanders (Belgium) at the primary and secondary collection points, WEEE is separated between reusable and non-reusable. A first visual selection is made to identify equipment, which then goes to re-use centres where it is either repaired or sold directly.

- Sweden proposed monetary incentives with the aim to promote the repairing of (W)EEE. The idea is to implement a law, which allows Swedes to claim back from their income tax up to half of the labour costs of repairing home appliances (e.g., washing machines or fridges). This could be quite substantial since most of the cost of repair is labour.

- Romanian NGO Ateliere Fara Frontiere provides work for formerly unemployable people that inter alia prepare WEEE for reuse. Therefore, cooperation with PROs that give access to this NGO to collected WEEE exist. The refurbished appliances are then donated to schools, kindergartens, and other indigent institutions.

Together with various electrical and electronic devices that are being used on a dayly basis, batteries and accumulators play an essential role to ensure that many daily-used products and services work properly, constituting an indispensable energy source in our society. Every year, approximately 800000 tons of automotive batteries, 190000 tons of industrial batteries, and 160 000 tons of consumer batteries enter the European Union. Not all of these batteries and accumulators are properly collected and recycled at the end of their useful life, increasing the risk of releasing hazardous substances and constitutes a waste of resources. Many of the components of these batteries and accumulators could be recycled, avoiding the release of hazardous substances into the environment and, in addition, providing valuable materials to important products and production processes. ${ }^{158}$

The Directive on batteries and accumulators ${ }^{159}$ has been adopted in 2006, establishing rules regarding the placing on the market of batteries and accumulators and in particular a prohibition on the placing on the market of batteries and accumulators containing hazardous substances; and establishing specific rules for the collection, treatment, recycling and disposal of waste batteries and accumulators to supplement relevant legislation on waste and to promote a high level of their collection and recycling. It seeks to improve the environmental performance of batteries

\footnotetext{
${ }^{156}$ EUROPEAN COMMISSION. Waste from Electrical and Electronic Equipment (WEEE). Available online at https://ec.europa.eu/environment/topics/waste-and-recycling/waste-electrical-and-electronic-equipment-weee_en. ${ }^{157}$ KLING, M. et al. WEEE Compliance Promotion Exercise: Final report. Munich, 2017, p. 77-78.

158 EUROPEAN COMMISSION. Batteries and accumulators. Available online at https://ec.europa.eu/environment/topics/waste-and-recycling/batteries-and-accumulators_en. 159 Directive 2006/66/EC of the European Parliament and of the Council of 6 September 2006 on batteries and accumulators and waste batteries and accumulators and repealing Directive 91/157/EEC. OJ L 266, p. 1-14.
} 
and accumulators and of the activities of all economic operators involved in their life cycle, e.g., producers, distributors, and end-users, and, in particular, those operators directly involved in the treatment and recycling of waste batteries and accumulators. ${ }^{160}$ The Directive has been yet followed by additional specific legislation. ${ }^{161}$

Within the frame of the Circular Economy Action Plan, referring to the goals of the European Green Deal, in December 2020 has been introduced by the Commission the proposal on new Regulation on batteries. ${ }^{162}$ It includes mandatory requirements for all batteries, i.e., industrial, automotive, electric vehicle and portable, placed on the EU market, such as use of responsibly sourced materials with restricted use of hazardous substances, minimum content of recycled materials, carbon footprint, performance and durability and labelling, as well as meeting collection and recycling targets. It is proposed that from 2024, only rechargeable batteries for industrial and electric vehicles, for which a carbon footprint declaration has been established, can be placed on the market. To close the loop and maintain valuable materials used in batteries for as long as possible in the European economy, the Commission proposes to establish new requirements and targets on the content of recycled materials and collection, treatment and recycling of batteries at the end-of-life part, e.g., to significantly improve the collection and recycling of portable batteries, as the current figure of $45 \%$ collection rate should rise to $65 \%$ in 2025 and $70 \%$ in $2030 .{ }^{163}$

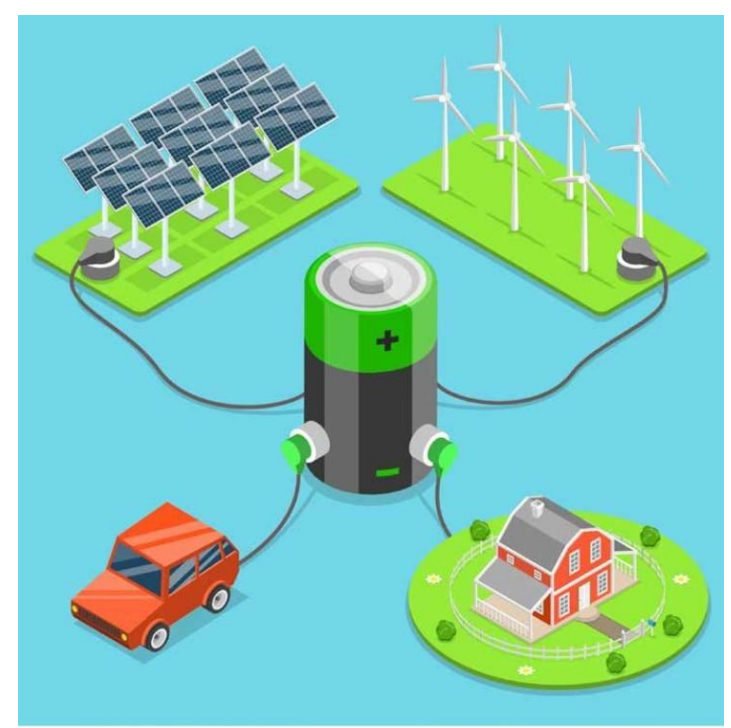

(c) TarikVision / Getty Images

\footnotetext{
160 Ibid., Article 1.

${ }^{161}$ Commission Decision 2008/763/EC establishing a common methodology for the calculation of annual sales of portable batteries and accumulators to end-users, Commission Decision 2009/851/EC establishing a questionnaire for Member States reports on the implementation of Directive on batteries and accumulators, Commission Regulation (EU) No 1103/2010 establishing rules as regards capacity labelling of portable secondary (rechargeable) and automotive batteries and accumulators, or the Commission Regulation (EU) No 493/2012 laying down detailed rules regarding the calculation of recycling efficiencies of the recycling processes of waste batteries and accumulators.

162 Proposal for a Regulation of the European Parliament and of the Council concerning batteries and waste batteries, repealing Directive 2006/66/EC and amending Regulation (EU) No 2019/1020. COM(2020) 798/3. 163 EUROPEAN COMMISSION. Green Deal: Sustainable batteries for a circular and climate neutral economy. Available online at https://ec.europa.eu/commission/presscorner/detail/en/ip_20_2312.

${ }^{164}$ EUROPEAN COMMISSION. Batteries and accumulators. Available online at https://ec.europa.eu/environment/topics/waste-and-recycling/batteries-and-accumulators_en.
} 


\section{Management of municipal waste in selected EU Member States Olga Kapplová, Liudmyla Golovko}

The following chapter provides an overview of the current legislation in the field of waste in three EU member states, the Czech Republic, Slovakia, and Poland. An important milestone for all these countries has been their accession to the EU on 1 May 2004.

However, the procedure of accession had been initiated earlier in 1990s, in case of Czech Republic and Slovakia immediately after their formation as separate states in 1993, together with other Central and East European Countries, including Poland. Pre-accession negotiations have been concluded in December 2002 at the Copenhagen European Council. At the meeting, individual chapters were closed and transitional periods for the adoption of European legislation were set. The European Council has set the above-mentioned date of the accession of the Czech Republic, Slovakia, and Poland and seven other European states.

\subsection{Management of municipal waste in the Czech Republic}

Within the transitional period was adopted the Waste Act, ${ }^{165}$ which entered into force on 1 January 1998. The Act stipulated the obligation of legal and natural persons in waste management and the conditions for waste prevention. It also determined the authority and competence of ministries and other administrative authorities and municipalities in the performance of state administration in the field of waste management. The Act, in contrast to the previous regulation, stipulated which types of waste remain out of its scope, namely wastewater, dumps and sludge ponds generated during mining activities, radioactive waste, dead animal bodies, or chemical substances and chemical preparations. ${ }^{166}$

In addition, basic terms such as waste and municipal waste were defined. Waste was defined as a movable thing that has become unnecessary for the owner and the owner disposes of it with the intention of disposing of it, or which has been discarded on the basis of a special legal regulation. Municipal waste was defined as all waste generated on the territory of the municipality during the activities of natural persons, for which no special rules or restrictions are laid down by legal regulations, with the exception of waste generated by legal entities or natural persons authorized to conduct business. Municipal waste was also waste generated during the cleaning of public roads and spaces, during the maintenance of public greenery, including cemeteries. ${ }^{167}$

A municipality was considered to be the producer of municipal waste generated on its territory, which originated in the activities of natural persons which were not subject to the obligations of the producer. The municipality was becoming a generator of municipal waste at the time when the natural person disposed of the waste at a designated place; at the same time, the municipality had become the owner of this waste. ${ }^{168}$

According to the Act, a municipality was obliged to determine places where natural persons could dispose municipal waste which they produce, including hazardous components such as batteries, paint residues, chemicals or fluorescent lamps. The obligation to provide places for the

\footnotetext{
165 Act No. 125/1997 Coll., on waste

166 \& 1 of the Act No. 125/1997 Coll., on waste

167 S 2 of the Act No. 125/1997 Coll., on waste

168 Ibid.
} 
disposal of hazardous components of municipal waste would have been fulfilled also by ensuring regular collection of this waste by an authorized person. ${ }^{169}$

The municipalities were allowed, in their self-governing competence, to stipulate by a generally binding decree the local system of collection, sorting, use, and disposal of municipal waste, including the system of construction waste management. The municipality was allowed, by the generally binding decree, to also set a fee for the collection, sorting, use, and disposal of waste, including the method of its collection. The fee was charged to individual taxpayers, i.e., natural persons whose activities generate municipal waste. The maximum level of the fee was determined based on the assumed eligible costs of the municipality resulting from the municipal waste management regime divided according to the number and volume of containers intended for waste disposal per individual property or according to the number of apartment users and with respect to the level of sorting of this waste. ${ }^{170}$

In 2001, the 1997 Act was repealed and replaced by another Act on Waste. ${ }^{171}$ The general principles of waste management and basis terms, as described above, were similar. But further, the new Act was amended several times with the purpose of incorporating relevant then valid EU directives. Based on that, the Act provided rules for waste prevention and management while respecting environmental protection, human health, and sustainable development, reducing the adverse effects of natural resource use and improving the efficiency of this use, rights, and obligations of persons in waste management, and the competence of public administration bodies in waste management.

Figure 7: Type and Amount of Municipal W aste in 2006 and 2014-2018172

\begin{tabular}{|c|c|c|c|c|c|c|}
\hline $\begin{array}{l}\text { Type and amount of } \\
\text { municipal waste }(t)\end{array}$ & 2006 & 2014 & 2015 & 2016 & 2017 & 2018 \\
\hline MW landfilled & 2043289 & 1826974 & 1755438 & 1789366 & 1765363 & 1828236 \\
\hline MW energy recovery & 390620 & 600147 & 585784 & 584159 & 629760 & 611192 \\
\hline $\begin{array}{l}\text { MW incinerated } \\
\text { without energy recovery }\end{array}$ & 1607 & 4008 & 4012 & 3865 & 4578 & 5047 \\
\hline MW recycled & 200603 & 736022 & 850907 & 957598 & 981934 & 1014946 \\
\hline MW composted & 23104 & 93429 & 141194 & 244626 & 261323 & 272797 \\
\hline
\end{tabular}

As of 1 January 2021, new Act on waste ${ }^{173}$ has entered in force. It has been prepared also on the basis of the EU legislation on circular economy. ${ }^{174}$ Compared to the previous legislation, the

\footnotetext{
169 S 9 of the Act No. 125/1997 Coll., on waste

$170 \int 10$ of the Act No. 125/1997 Coll., on waste

171 Act No. 185/2001 Coll., on waste

172 CZECH STATISTICAL OFFICE. Generation, Recovery and Disposal of Waste. Available online at https://www.czso.cz/csu/czso/produkce-vyuziti-a-odstraneni-odpadu-2018.

173 Act No. 541/2020 Coll., on waste

174 Directive 2018/849 amending Directive 2000/53/EC on end-of-life vehicles, 2006/66/EC on batteries and accumulators and waste batteries and accumulators and 2012/19 / EU on waste electrical and electronic equipment; Directive 2018/850 amending Directive 1999/31 / EC on the landfill of waste; Directive 2018/851 amending
} 
new Act contains several significant changes that will affect not only ordinary citizens, but also entrepreneurs and municipalities. The purpose of this Act is to ensure a high level of protection of the environment and human health, sustainable use of natural resources by preventing the generation and management of waste in accordance with the waste hierarchy while maintaining social sustainability and economic acceptability, and to allow transition to a circular economy. ${ }^{175}$ The Act incorporates and follows relevant EU legislation and provides rules for waste prevention and management, rights and obligations of natural and legal persons, and the competence of public authorities.

Waste management means activities aimed at the prevention of waste generation, waste treatment, subsequent care of the places where waste is permanently stored, mediation of waste management, and the control of these activities. It shall be based on a waste management hierarchy, according to which the priority is to prevent waste and, if waste cannot be prevented, to prepare it for re-use, recycling, other uses, including energy recovery, including classification according to the Waste Catalogue. The Act authorizes the Ministry of Environment to issue a decree on the Waste Catalogue and the procedure for classifying waste and assessing properties according to this Catalogue.

Within the waste management hierarchy, the whole life cycle of products and materials should be taken into account, in particular with regard to reducing the effects of waste management on the environment and human health; the principle of precaution and sustainability; technical feasibility and economic sustainability; protection of resources, the environment, human health and economic and social impacts; and objectives, principles, and measures of the Waste Management Plan of the Czech Republic. Deviation from this hierarchy is allowed in the case of wastes where this is appropriate, having regard to the best environmental and human health outcome, taking into account the overall impacts of the life cycle of products and materials involving the generation and management of the waste. ${ }^{176}$

State administration in the area of waste management is performed by the following bodies: Ministry of Environment, Ministry of Industry and Trade, Ministry of Agriculture, Central Agricultural Inspection and Testing Institute, Ministry of Health, regional hygienic stations, inspections, customs offices and the General Directorate of Customs, Police of the Czech Republic, regional authorities, municipal authorities, district offices, and the State Environmental Fund of the Czech Republic. ${ }^{177}$

Figure 8: Central State Administration Bodies, Subordinate Bodies and their Competencies

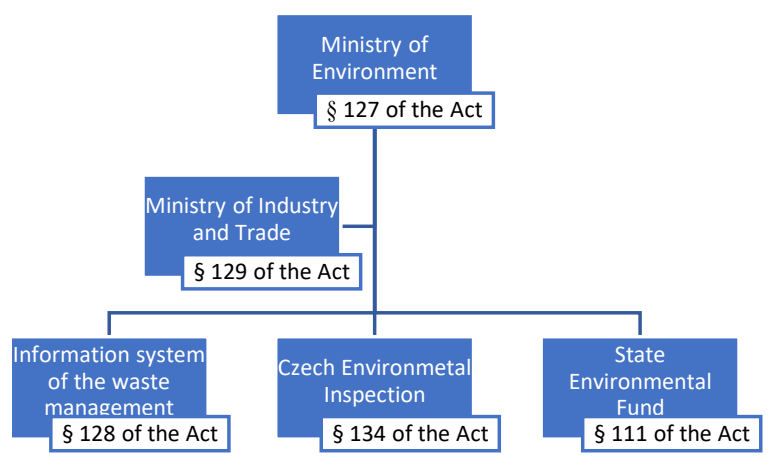

Directive 2008/98 / EC on waste; Directive 2018/852 amending Directive 94/62 / EC on packaging and packaging waste.

175 \$ 1 of the Act No. 541/2020 Coll., on waste

$176 \int 3$ of the Act No. 541/2020 Coll., on waste

$177 \int 126$ of the Act No. 541/2020 Coll., on waste 
The Act further specifies and stipulates other obligations of waste generators, but it remains that municipal waste and other usable components of waste, especially the method of disposal and fees, are set by municipalities in their decrees.

The definition of municipal waste, for which the law stipulates the obligations of the municipality with its disposal, can be found in the law: ${ }^{178}$ Municipal waste means mixed and sorted household waste, especially paper and cardboard, glass, metals, plastics, biological waste, wood, textiles, packaging, waste electrical and electronic equipment, waste batteries and accumulators, and bulky waste, especially mattresses and furniture, and mixed waste and sorted waste from other sources if it is similar in nature and composition to household waste; municipal waste does not include waste from production, agriculture, forestry, fishing, septic tanks, sewers and sewage treatment plants, including sludge, end-of-life vehicles or construction and demolition waste. Bio-waste means biodegradable waste from gardens and public greenery, food and kitchen waste from households, offices, restaurants, wholesale, canteens, catering or retail establishments, and comparable waste from food industry establishments. Construction and demolition waste means waste generated during construction and demolition activities.

Except to take the necessary number of waste samples for analysis, testing or analysis for scientific, research and development purposes, to determine the acceptability of waste in a waste facility, to categorize waste, to assess hazardous properties of waste and further analyses and tests necessary to ensure waste management in accordance with the legislation, the following bodies are entitled to take over waste: a) the operator of a facility designated for the management of a given type and category of waste, b) a waste trader with a permit for the given type and category of waste, $c$ ) the municipality under the conditions set out in $\ 59$, or d) a legal entity performing the activity of a school or school facility or a university under the conditions set out in $\int 20$. The producer of waste means the municipality from the moment when the person disposes of waste according to $\ 59$ and 60 to the place of municipalities designated for this purpose.

With the entry into force of the new Act on waste, the fees for depositing waste in landfills were increased, but municipalities are entitled to a so-called sorting discount for meeting the statutory requirements. ${ }^{179}$ Until the end of 2029 (i.e., until the ban on landfilling of usable waste comes into force), municipalities can deposit usable municipal waste in a landfill at a reduced rate. However, the law stipulates the maximum amount of such waste that can be landfilled at a reduced rate.

Municipalities are now obliged to designate places for separate collection of recyclable components of municipal waste (i.e., hazardous waste, paper, plastics, glass, metals, biological waste, edible oils, and fats) and, from 1 January 2025, also textiles. Municipalities are obliged to ensure that separately concentrated components of municipal waste make up at least $60 \%$ in 2025 - 2029, at least $65 \%$ in 2030 - 2034 and from 2035 at least $70 \%$ of the total amount of municipal waste generated by the municipality in a given year. In order for municipalities to meet these objectives, they will have to ensure the sorting of significantly more individual components of municipal waste than before. Municipalities will have to focus mainly on a thorough sorting of biowaste (without a thorough sorting in this area, according to the legislator, it will not be possible to achieve the objectives). ${ }^{180}$

To fulfil the obligations of the above, the municipality shall set up a municipal waste management system. The municipal system may be set up by the municipality in a generally binding decree. If the municipality sets up the municipal system by a generally binding decree, it

$178 \int 11$ of the Act No. 541/2020 Coll., on waste

$179 \int 157$ of the Act No. 541/2020 Coll., on waste

$180 \int 59$ of the Act No. 541/2020 Coll., on waste 
may at the same time determine by this decree the places in which it will take over within the municipal system a) construction and demolition waste generated on the territory of the municipality during the activities of non-entrepreneurial natural persons, b) movables in the framework of waste prevention, c) municipal waste generated on the territory of the municipality during the activities of legal and entrepreneurial natural persons who join the municipal system on the basis of a written contract; in such a case, the municipality must, by a generally binding decree set up by the municipal system, specify at least the types of waste that a legal or entrepreneurial natural person may transfer to the municipal system, the method of determining the amount of payment for participation in the municipal system and the method of its collection, d) end-of-life products in the event that it takes over them as part of a service for manufacturers under the Act on End-of-Life Products, or e) plant residues from the maintenance of greenery, gardens and households for processing into compost within the framework of community composting. The municipality may, by a generally binding decree set by the municipal system, stipulate the obligations of persons related to the transfer of waste and movable property to the municipal system.

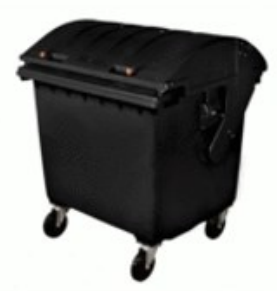

Municipal Waste

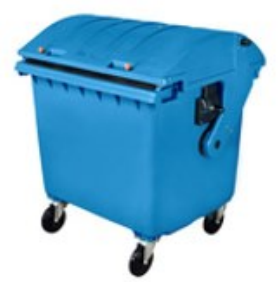

Paper Waste

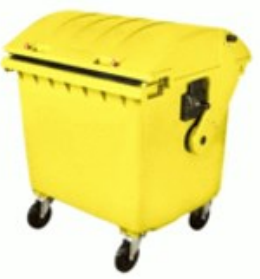

Plastic Waste

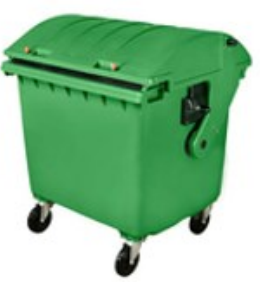

Glass Waste

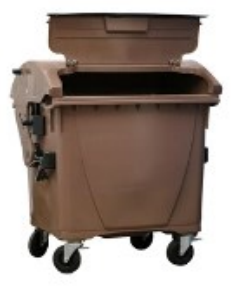

Biological Waste

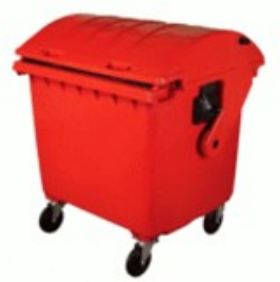

Beverage Box Waste

Recently, many municipalities are switching to a new system of collection and storage of sorted waste in underground containers, which in terms of waste disposal creates a more pleasant and cleaner environment. Garbage is often lying around waste containers, due to their overcrowding. The underground containers extend below the surface. Their main advantage is that they save space, and garbage remains out of reach of vandals, relentless winds, or rodents. Another advantage is that they improve the aesthetics of the surroundings, in the summer passers-by are not attacked by unpleasant odours, it is not necessary to export them so often, both due to the volume and due to lower temperatures in the underground. The disadvantage of these containers is their higher price, compared to above-ground containers, and then also the maintenance of underground containers, which must be emptied by a special vehicle equipped with a hydraulic arm. 


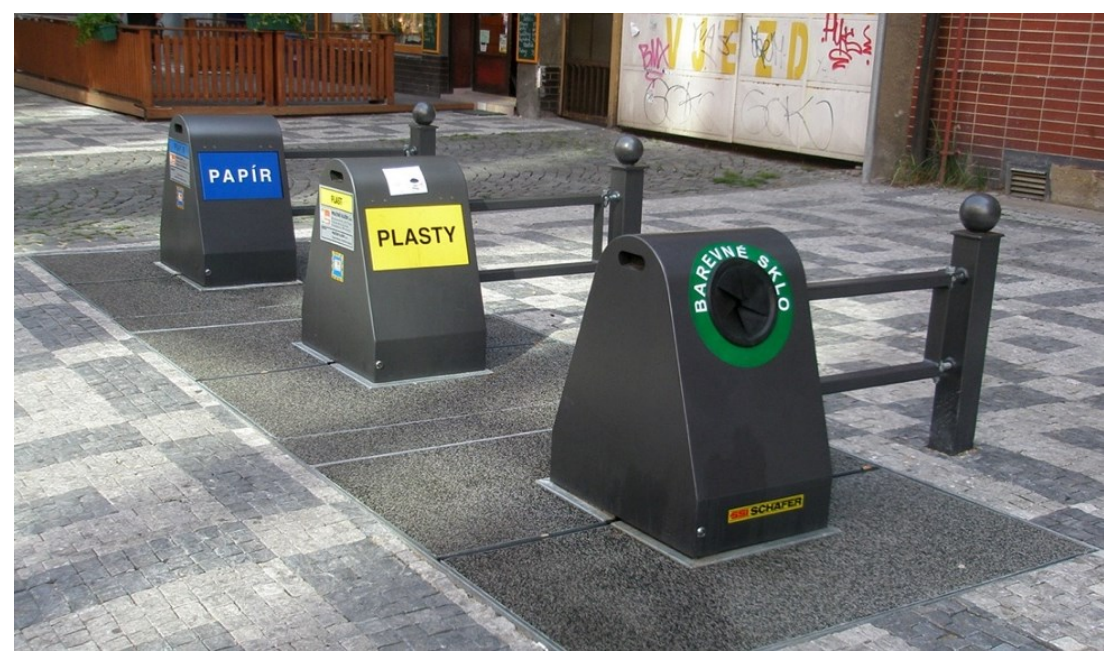

In some municipalities, they also start collecting and sorting cans, which is done by grey garbage cans. The next step will be sorting of textile waste. In addition, municipalities lead citizens to store construction waste in specialized landfills, where this waste is further processed and used as a raw material for construction companies. In some municipalities, they have also started to store edible oils and fats in special containers.

In the case of biological waste, either the municipality itself has a facility where it further processes this waste or, in cooperation with another municipality, passes this waste on for further processing. Thus, for example, composting plants are created, where quality compost is created as part of storage and further process, which is then used either by citizens for their gardens, or by the municipality itself to establish new fertile areas, improve soil in parks or public spaces.

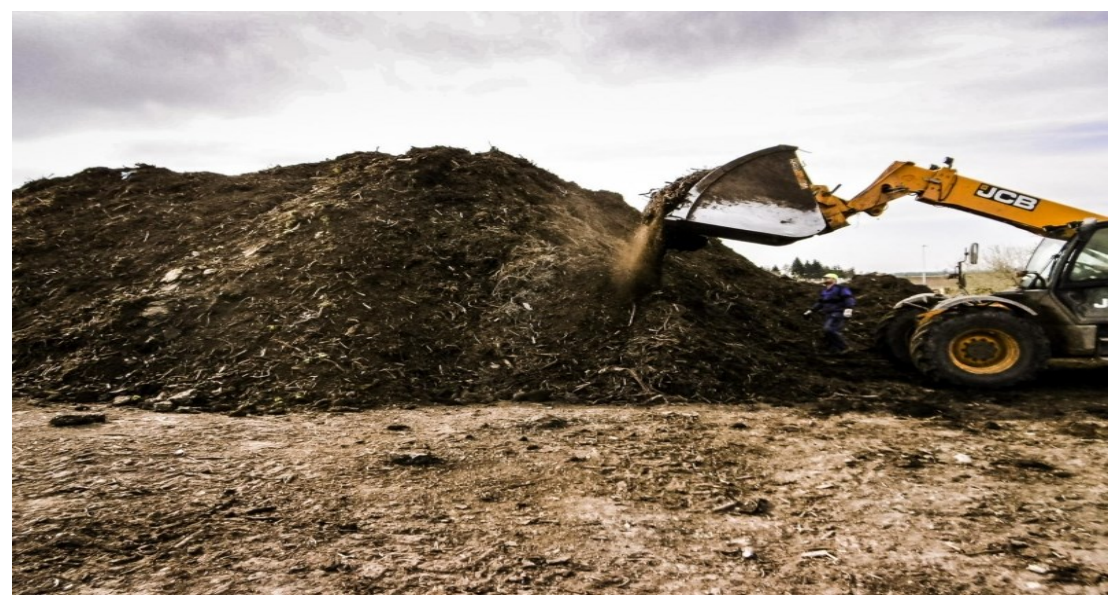

${ }^{181}$ KOMPOSTÁRNA NÁKLO. Available online at http://www.tsnaklo.cz/kompostarna. 


\subsection{Management of municipal waste in Poland}

According to the Directive on waste, EU member states must develop a National Waste

Management Action Plan. Currently, Poland has a National Action Plan adopted in 2016 and will be valid until 2022. ${ }^{182}$ In addition, each region (voivodship) develops regional action plans for waste management. Both national and regional waste action plans pay close attention to household waste.

In September 2019, the Government of Poland adopted document called Roadmap: Transformation to a Circular Economy. The concept of a circular economy assumes that all elements of the production chain, products, materials and raw materials remain in circulation as long as possible. The generation of waste should be minimal. According to the Roadmap, Poland's priorities in the circular economy are innovation, strengthening cooperation between industry and the scientific sector, and, as a result, the introduction of innovative solutions in the economy. Further, also to create a European market for secondary raw materials, which is easier to handle. Special attention is paid to sustainable consumption, in particular the reduction of food waste. ${ }^{183}$

The main normative legal acts currently regulating solid waste management at the municipal level in Poland are the Act on waste ${ }^{184}$ and the Act on maintaining cleanliness and order in municipalities. ${ }^{185}$ The Act on waste defines measures to protect the environment, human life and health, prevent and reduce the negative impact on the environment and human health due to the generation and management of waste, and limit the overall consequences of the use of resources and increase the efficiency of such use. ${ }^{186}$

According to the Act on waste, ${ }^{187}$ municipal waste means waste generated by households, with the exception of end-of-life vehicles, as well as waste that does not contain hazardous waste from other waste producers, which is similar in nature or composition to household waste; unsorted (mixed) municipal waste remains unsorted (mixed) municipal waste, even if it has undergone a waste treatment process that has not significantly changed its characteristics; green waste means municipal waste, which forms part of plants from the care of green areas, gardens, parks and cemeteries, as well as from marketplaces, with the exception of waste from street and square cleaning.

The entity collecting municipal waste from property owners is required to hand over unsorted (mixed) municipal waste to the municipal facility to ensure its treatment. Waste management entities are required to keep waste registration documents. Among these entities belong those who are collecting, transporting and treating the municipal waste. ${ }^{188}$

In 2013, the responsibility for municipal waste management in Poland was assigned to local governments, which were required to establish local municipal waste collection systems.

Moreover, conditions must be created for separate waste collection. Since then, local authorities set their own prices and are responsible for garbage removal, sorting, and recycling. Waste, in accordance with the hierarchy of waste management methods, is first recycled where it is generated. Waste that cannot be recycled where it is generated must be transferred, considering the hierarchy of waste management methods and the best available technology specified in

182 Resolution No. 88 of the Council of Ministers of 1 July 2016 on the National Waste Management Plan 2022. 183 MINISTERSTWO ROZWOJU, PRACY I TECHNOLOGII. Rada Ministrów przyjęła projekt Mapy drogowej GOZ. Available online at https://www.gov.pl/web/rozwoj-praca-technologia/rada-ministrow-przyjela-projektmapy-drogowej-goz.

184 Act of 14 December 2012 on waste

185 Act of 25 January 2013 amending the act on maintaining cleanliness and order in municipalities

186 Article 1 of the Act of 14 December 2012 on waste

187 Article 3 of the Act of 14 December 2012 on waste

188 Articles 29a and 67 of the Act of 14 December 2012 on waste 
Article 207 of the Act on Environmental Protection ${ }^{189}$ or technology specified in Article 143 of the Act on waste, to the nearest places where they can be treated. To this end, local authorities organize tenders for the provision of such services to residents of cities and villages. Thus, Poland stimulates competition, and thus forces the local authorities to provide the population with the highest quality services. ${ }^{190}$

The Act on maintaining cleanliness and order in municipalities defines the following tasks of local councils: to ensure cleanliness and order in their territories and create the conditions necessary for their maintenance, in particular:

- Create conditions for the performance of works related to the maintenance of cleanliness and order on the territory of the local council or ensure the performance of these works by creating appropriate organizational units.

- Provide construction, maintenance and operation of their own or joint with other local councils: a) regional technological facilities for the processing of household waste - if the obligation to build such technological facilities arises from the voivodship waste management plan; b) drainage stations, if it is impossible to connect all the property to the sewer system or it causes excessive costs; c) technological equipment and devices for the collection, transportation and disposal of animal carcasses or parts thereof; d) public toilets.

- Cover all property owners in the village or city council with a system of household waste management.

- Control the management of household waste, including the implementation of tasks assigned to economic entities that collect household waste from property owners.

- Establish separate collection of household waste, covering at least such waste fractions as: paper, metal, plastic, glass and multicomponent packaging and household waste subject to biodegradation, including packaging waste subject to biodegradation.

- Establish separate collection points for household waste in such a way that provides easy access for all local councils that provide at least the reception of household waste such as: expired medicines and chemicals, used batteries and accumulators, used electrical and electronic equipment, furniture and other bulky waste, used tires, green waste and construction or demolition waste, which are household waste, as well as household waste specified in other regulations.

- Ensure the achievement of appropriate levels of recycling, preparation for reuse and recovery in other ways and reduction of the mass of household waste subject to biodegradation, which is transferred for storage.

- Carry out informational and educational activities in the field of proper management of household waste, especially in the field of separate collection of household waste.

- Place on the website of the municipal body and in the usual way information about: entities that collect household waste from property owners from the territory of the local council, places of economic activity of entities that collect waste, achievements of the local council and entities, which carry out the collection of household waste, the required levels of recycling of waste, the points of separate collection of household waste, which collect used electrical and electronic equipment that comes from households.

- Conduct an annual analysis of the state of municipal waste management to check the technical and organizational capabilities of the local council in the field of municipal waste management.

\footnotetext{
189 Act of 27 April 2001 on environmental protection

190 SAVITSKY, Y. Poles who do not sort garbage will be forced to pay. Available online at https://www.radiosvoboda.org/a/25080193.html.
} 
- Prevent pollution of streets, squares and open areas, in particular by: collection and disposal of swamp, snow, ice and other contaminants removed from sidewalks by property owners, as well as waste collected in specially designed containers placed on the sidewalk.

- Maintain cleanliness and order at bus stops owned or operated by the village / city council.

- Determine the requirements for persons who keep pets for safety and cleanliness in public places.

- Prevent homelessness of animals, provide collection, transportation and destruction of corpses of stray animals, and mark the areas affected or at risk of infectious animal disease.

The session of the city council adopts regulations on maintaining cleanliness and order in the territory of the city council, which is an act of local law. The regulations set out detailed rules to maintain cleanliness and order in the local council. ${ }^{191}$

In 2016, new rules for waste collection and separation were introduced by the Order of the Minister of Environment. ${ }^{192}$ According to these rules was introduced a new system of municipal waste collection, which should consist of five fractions (previously there were three), which residents must separate: paper, glass, metals, plastics and biodegradable waste.

As a result of the amendment to the Act on maintenance of cleanliness and order in municipalities, starting from 1 January 2019 in Poland, in case of non-compliance with the requirement of separate waste collection, citizens must pay four times more than for sorted waste. ${ }^{193}$ The amendment also stipulates that the fee for garbage will be lower for those who have their own composters. The provisions of the amendment also regulate the collection of waste from non-residential real estate where waste is generated, such as from shopping centres. Owners of these facilities will be able to voluntarily join the municipal waste system. ${ }^{194}$

In January 2020, a new waste register has been introduced. The register includes business entities that import products, packaged products, and contains information related to their waste management. It enables the collection of waste information and ensures the electronic fulfilment of registration, record, and reporting obligations. The obligation to be included in the register applies to entrepreneurs who produce waste and keep records of this waste; import packaged products, tires, lubricants, vehicles, accumulators, electrical and electronic equipment into the territory of the country; manufacture or import packaging or buy it as part of internal transactions. The register is kept by voivodship marshals. Depending on the type of business, entrepreneurs join it at their request or ex officio, i. e. without the need for the applicant to submit an application. ${ }^{195}$ Individuals who conduct business or entrepreneurs who, as part of their activities, produce only waste with the composition and nature of municipal waste and are covered by the municipal waste collection system, are exempted from the obligation to enter in

\footnotetext{
191 Article 3 of the Act on maintaining cleanliness and order in municipalities

192 Order of the Minister of the Environment of 29 December 2016 on the detailed method of selective collection of selected waste fractions

${ }^{193}$ KUBICKA-ZACH, K., CYRANKIEWICZ-GORTYNSKI, M. Za rok 5-pojemnikowa segregacja śmieci wkroczy do wszystkich gmin. Available online at https://www.prawo.pl/samorzad/segregacja-smieci-od-2019roku,347745.html.

${ }^{194}$ KACZMAREK, Z. Nowelizacja ustawy o utrzymaniu czystości i porządku w gminach - wejście w życie nowelizowanych przepisów. Available online at https://sozosfera.pl/odpady/nowelizacja-ustawy-O-utrzymaniuczystosci-2/.

${ }^{195}$ BIZNES.GOV.PL. Wpis do rejestru BDO (podmioty wprowadzające produkty, produkty w opakowaniach i gospodarujące odpadami). Available online at https://www.biznes.gov.pl/pl/firma/obowiazki-przedsiebiorcy/chcewypelniac-obowiazki-srodowiskowe/proc_170-wpis-do-rejestru-bdo-podmioty-wprowadzajace-produkty-produktyw-opakowaniach-i-gospodarujace-odpadami.
} 
the register. This exemption may relate to, for example, small services, administrative and office activities, law firms, or accounting. ${ }^{196}$

The aim of waste management, in accordance with requirements of the EU legislation, is to reduce the percentage of landfilling. In 2009, it was produced 11 mil. tons of waste, of which 10,4 tons were unseparated. At that time, there were about 2,500 landfills in Poland and their number dropped to 762 . Within 15 years, Poland has managed to reduce the level of waste disposal from $97 \%$ to $42 \%$. In addition to the development of the recycling industry, thanks in particular to the work of the public to stimulate sorting, this was facilitated by a real boom in the construction of incinerators. Since joining the EU, seven facilities have been opened and the construction of two more plants has been approved. Of course, this happened with significant financial support from the EU, as the cost of such projects is estimated at tens of millions of euros. By moving from the lowest level of the waste hierarchy to recovery, Poland has strengthened its energy independence through the use of waste-to-energy technology. After all, in the process of combustion, the plant generates energy that can supply consumers. ${ }^{197}$

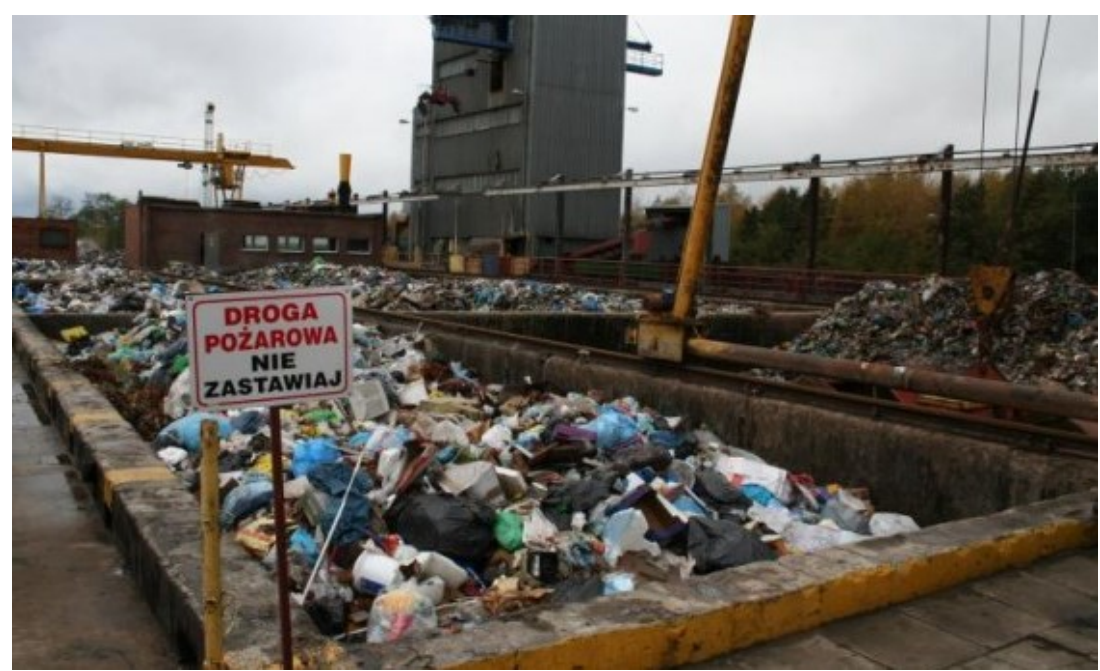

In contrast to the legislation of the Czech Republic and Slovakia, where we find public

administration and self-government bodies and their competence, the law of the Republic of Poland is perceived in the opposite way. The law defines measures to protect the environment, human life, and health, prevent, and reduce the negative impact on the environment and human health resulting from the production and management of waste, as well as reduce the overall consequences of resource use and increase the efficiency of this use. The law defines certain terms. Other parts of the law list some areas of waste management. In these areas, the specific powers of individual public authorities and local governments are listed. For a better understanding, it is necessary to describe how the state administration works in Poland. Public administration in Poland is carried out by the main public administration bodies and central public administration bodies. The main bodies of public administration can be considered the

${ }^{196}$ BIZNES.GOV.PL. Odpady - rejestracja, ewidencja i sprawozdawczość. Available online at https://www.biznes.gov.pl/pl/firma/obowiazki-przedsiebiorcy/chce-wypelniac-obowiazki-srodowiskowe/odpadyw-2020-r-rejestracja-ewidencja-i-sprawozdawczosc.

${ }^{197}$ NECHITAYLO, D. et al. From the third world to the first. Waste management reform in Ukraine. PWC, 2020. Available online at https://www.pwc.com/ua/en/survey/2020/waste-management.pdf. 198 PALECEK, R. Systém nakládání s odpady v polské Zielenoj Gorze. Available online at https://www.komunalweb.cz/system-nakladani-s-odpady-v-polske-zielonej-gorze. 
Council of Ministers, individual ministers, and the Prime Minister. The central state administration consists of bodies called the main state administration. We also distinguish between the so-called local state administration, which includes dukes, non-associated governing bodies, and associated governing bodies.

The Ministry of Climate and Environment is responsible for developing a national waste management strategy and developing a policy that focuses on reducing and recycling waste. The Ministry of Economy sets technical standards for waste management. The Ministry of Health focuses on the preparation of environmental regulations related to the recycling and reduction of sanitary waste. Environmental protection is controlled by inspection bodies, which include the Chief Environmental Inspector, the National Environmental Inspectorate, and the Department of Environmental Protection. The above-mentioned bodies perform the task of setting environmental quality standards and determining regulations on environmental supervision; they control activities closely related to the functioning of the national system; check whether the subjects comply with the rules of environmental protection; organize and coordinate national environmental monitoring, conduct environmental quality research, monitor and assess the state of the environment; develop analytical and research methods, methods of measurement and control. ${ }^{199}$ There is also a municipal police in Poland that monitors the cleanliness and proper sorting of garbage. It has right to check whether there are necessary garbage cans, including for biodegradable waste, and it also checks whether the actual status of the submitted declaration on the amount of the fee for municipal waste. ${ }^{200}$

It is obvious that the management of municipal and other waste is a long-term process which includes many aspects. Especially when it comes to small municipalities, where citizens have not yet taken it as their own to sort waste. That may result even into ecological disasters, such as pollution of river Tisza, flowing through Ukraine, Slovakia and Hungary into the Danube and further into the Black Sea.

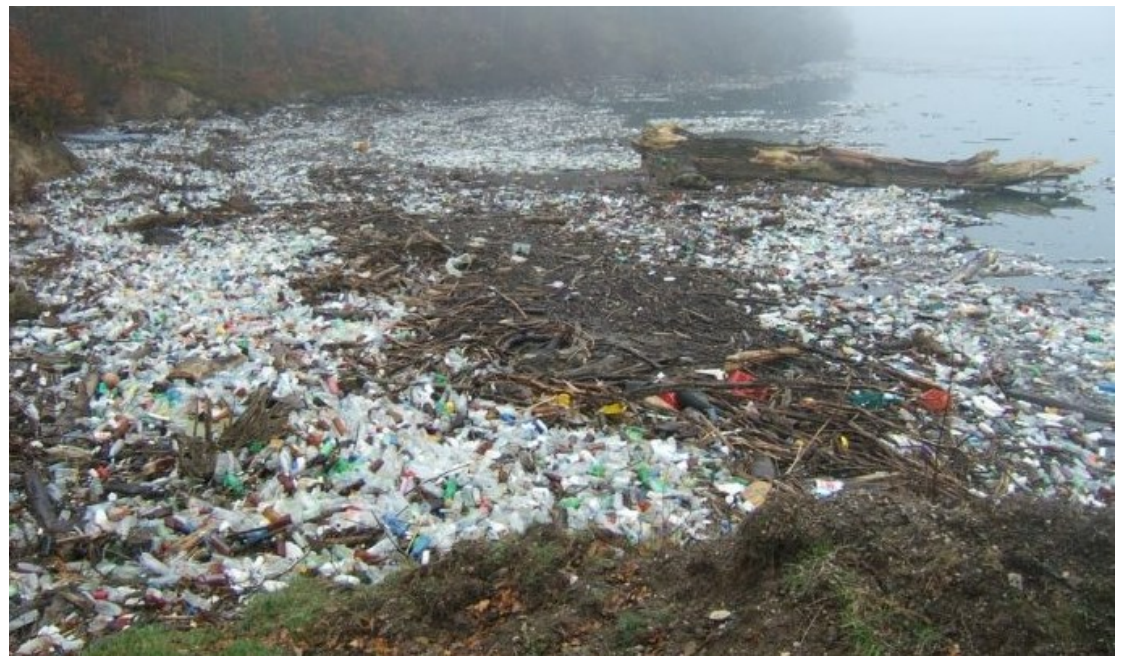

\footnotetext{
199 ALWAELI, M. An overview of municipal solid waste management in Poland. The current situation, problems and challenges. Environmental Protection Engineering, 2015, Vol. 41. № 4, p. 181-193.

${ }^{200}$ URZAD MIASTA POZNANIA. Straż miejska skontroluje segregację odpadów. Available online at https://www.teraz-srodowisko.pl/aktualnosci/straz-miejska-skontroluje-segregacje-odpadow-5320.html. 201 SMOLÁKOVÁ, D. Ekologická katastrofa na řece Tise. Zaplavuji ji tisíce tun plastového odpadu. Available online at https://udalosti247.cz/zahranici/reku-tisu-zaplavuji-tuny-plastoveho-odpadu/.
} 


\subsection{Management of municipal waste in Slovakia}

Waste management in the Slovak Republic is based on state environmental policy. This is represented by the Waste Management Program of the Slovak Republic, which is a basic conceptual document for the development of waste management also in individual regions and municipalities. It applies to the management of all types of waste. The binding part of the Program is important for the decision-making activities of the state administration bodies of the Slovak Republic.

Legal regime of waste management in Slovakia is currently set by the Act on Waste ${ }^{202}$ which has entered into force on 1 January 2016, repealing the previous legislation. ${ }^{203}$ Waste is defined as any movable thing which a person disposes of or has the intention or obligation to dispose of. If a movable item meets the following definition of waste, the obligations imposed by law apply to it.

The Act also specifies the conditions for waste disposal and stipulates its hierarchy from waste prevention through recycling, energy recovery to its disposal. A person shall hand over a movable thing for use or disposal within the meaning of this Act, if he hands it over to a person authorized to collect or purchase waste pursuant to this Act, regardless of whether it is a gratuitous or gratuitous transfer. Disposal also occurs in a situation where the person himself removes the movable property.

The bodies of the state administration of waste management are the Ministry of Environment, the Slovak Environmental Inspectorate, the district office in the seat of the region, district office, municipality, the Slovak Trade Inspection, customs office and the Criminal Office of Financial Administration. ${ }^{204}$

The Ministry of Environment manages and controls the performance of state administration in waste management, processes, issues, updates, and publishes the Program of the Slovak Republic and the Waste Prevention Program. It is a body of state supervision in waste management. It also cooperates with central state administration bodies and other legal entities in ensuring the uniform application of general binding regulations in waste management. In the framework of international cooperation, it shall consult with the competent authorities of the Member States on measures taken by law with regard to the impact of activities carried out in another state. ${ }^{205}$

Slovak Environmental Inspectorate is a state supervisory body in waste management, imposes fines, decides in disputes whether the goods are waste in the case of transport across borders, is authorized to carry out documentary checks in the area of cross-border movement of waste under special regulations, monitors cross-border transport of suspicious electrical equipment, is authorized inspect ship recycling facilities and monitor the cross-border shipment of used nonwaste batteries and accumulators and other activities. ${ }^{206}$

The district office in the seat of the region in matters of state administration of waste management is a decision-making and approving body, it imposes fines for breach of obligations arising from the law, issues statements on the establishment of waste incinerators, or gives consent to shipments of hazardous waste beyond the district. ${ }^{207}$

\footnotetext{
202 Act No. 79/2015 Coll., on waste

203 Act No. 223/2001 Coll., on waste

$204 \int 104$ of the Act No. 79/2015 Coll., on waste

$205 \int 105$ of the Act No. 79/2015 Coll., on waste

$206 \int 42$ and $₫ 106$ of the Act No. 79/2015 Coll., on waste

207 \$ 107 of the Act No. 79/2015 Coll., on waste
} 
The district office in matters of state administration of waste management, for example, prepares documents for the elaboration of the regional program and the program of the Slovak Republic, issues a certificate of closure of a landfill, or registers and maintains a list of registered persons. It is a body of state supervision in waste management, imposes fines, discusses offenses and comments on municipal zoning plans, and exercises other obligations that are not addressed by other authorities. ${ }^{208}$

The municipality discusses offenses in waste management, and imposes fines for offenses, and provides the waste holder with information on the location and activities of waste management facilities in the municipality. ${ }^{209}$

Slovak Trade Inspection in matters of state administration of waste management is a body of state supervision in waste management, in order to control compliance with the obligations specified in the law with regard to facilities containing biphenyls, which are not waste under the law. Inspectors of the Slovak Trade Inspection Authority are authorized to enter storage and sales premises, take samples of equipment and products for testing, request accompanying sheets of equipment and products, or to check the designation of equipment and products that are put into circulation. ${ }^{210}$

In the case of transboundary movement of waste, the competent customs authorities and the Criminal Office of the Financial Administration are responsible for checking the conformity of documents with waste, whether the transboundary movement of waste is in conflict with special regulations, whether the transported waste corresponds to the facts in the attached documents. ${ }^{211}$

The basic terms for the area of municipal waste are regulated in the law ${ }^{212}$ as follows: Municipal waste is mixed waste and separately collected household waste, including paper and cardboard, glass, metals, plastics, biological waste, wood, textiles, packaging, waste from electrical and electronic equipment, used batteries and accumulators and bulky waste, including mattresses and furniture. Mixed waste and separately collected waste from other sources if this waste is similar in nature and composition to household waste. A component of municipal waste is its part, which can be mechanically separated and classified as a separate type of waste. A component of municipal waste is considered to be sorted if it does not contain other components of municipal waste or other impurities that can be classified as separate types of waste. Mixed waste is unsorted municipal waste or municipal waste after sorting components. Small construction waste is waste from routine maintenance work performed by a natural person or for a natural person, for which a local fee is paid for municipal waste and small construction waste.

In Slovakia, the municipality is responsible for municipal waste management. The costs of the collection container for mixed municipal waste are borne by the original waste generator, i. e. the citizen. The municipality stipulates in a generally binding decree the amount of these costs and their inclusion in the local fee for municipal waste and small construction waste or stipulates another method of their payment. The costs of securing collection containers for separate collection of municipal waste components, for which the extended responsibility of producers does not apply, are borne by the municipality and may be included in the local fee for municipal waste and small construction waste. ${ }^{213}$ Containers for sorted waste are similar, as mentioned above for the Czech Republic. Municipalities on their websites inform residents in detail how to dispose of waste, to which waste belongs or, conversely, does not belong. The sorting of waste and its management is again based on the hierarchy, i.e., the use of its components for further

\footnotetext{
208 \ $98, \int 99, \int 112, \int 115$ and $\int 117$ of the Act No. 79/2015 Coll., on waste

$209 \int 109$ of the Act No. 79/2015 Coll., on waste

210 \$ 110 and $\int 117$ of the Act No. 79/2015 Coll., on waste

$211 \int 111$ and $\int 117$ of the Act No. 79/2015 Coll., on waste

$212 \int 80$ of the Act No. 79/2015 Coll., on waste

$213 \int 81$ of the Act No. 79/2015 Coll., on waste
} 
processing, and only what cannot be further processed is stored in places designated for that purpose.

According to the Act on waste, ${ }^{214}$ the aim of municipal waste management in Slovakia is to increase by 2020 the preparation for reuse and recycling of household waste such as paper, metal, plastics and glass and, if possible, from other sources, if these sources contain similar waste as household waste, to at least $50 \%$ by weight of such waste generated in the previous calendar year. The aim of municipal waste management is also to increase the preparation for reuse and recycling of municipal waste to at least $55 \%$ by 2025 , at least $60 \%$ by 2030 and at least $65 \%$ by 2035 , depending on the weight of municipal waste generated in the previous calendar year, and to reduce the amount of municipal waste disposed of by landfill to at least 10 $\%$ of the total amount of municipal waste generated by 2035 . And finally, in the field of construction and demolition waste, to increase by 2020 the preparation for re-use, recycling and recovery of construction and demolition waste, including backfilling, as a substitute for other materials in each calendar year to at least $70 \%$ by weight. waste generated in the previous calendar year.

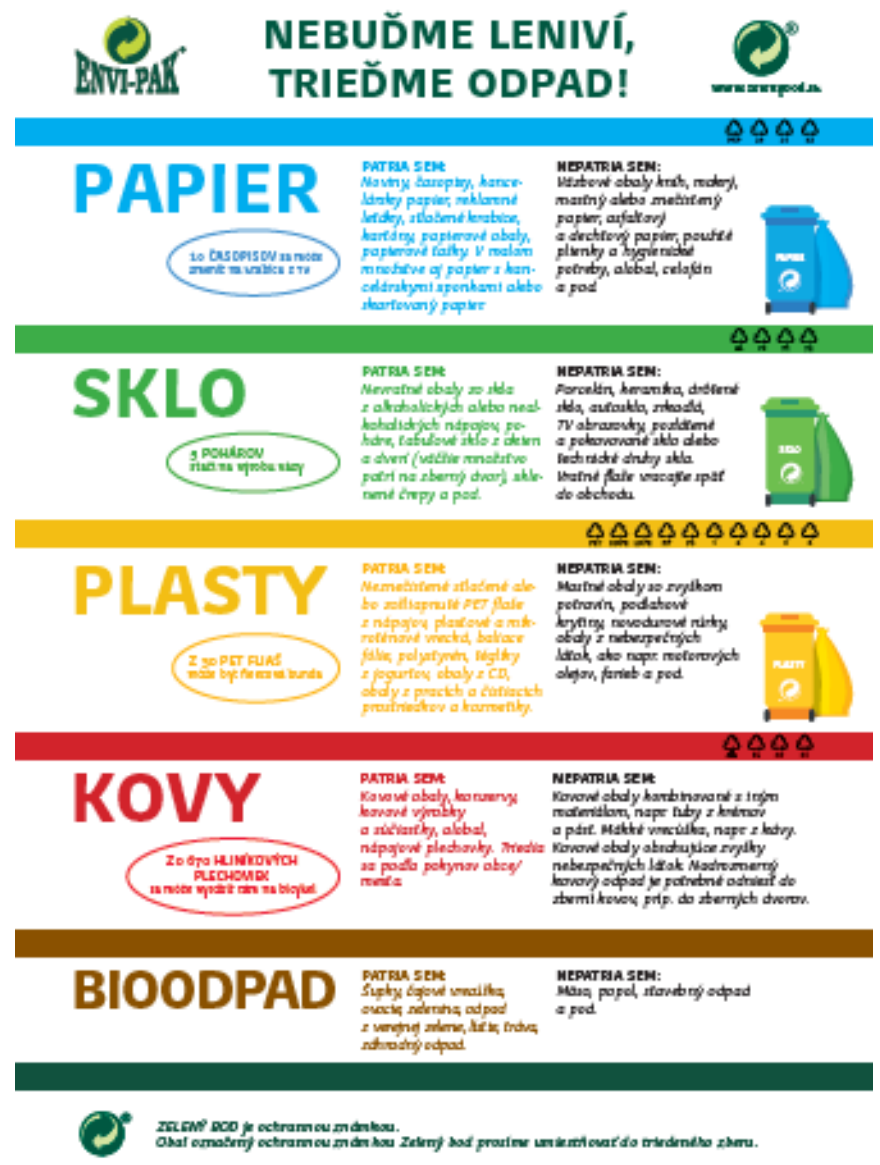

214 Annex 1 of the Act No. 79/2015 Coll., on waste

215 BANSKÁ BYSTRICA. Available online at https://www.banskabystrica.sk. 


\section{Contribution of the EU Cohesion Policy to the management of municipal waste}

Lenka Smékalová

The cohesion policy is a multifaceted policy of the European Union intended to tackle social, economic and environmental issues inside the very diverse European Union. The countries of central and eastern Europe presently benefit on a large scale from this policy. ${ }^{216}$ It runs in sevenyear-long cycles since the year 2000 and has gradually evolved into a very visible, perhaps most discussed investments policy of the Union. Its emphasis on environmental issues is significant and embedded in the 2014-2020 period legislation regulating the policy itself, requiring thematic concentration on specified objectives of Europe 2020 Strategy and names 11 thematic objectives, three of which are directly related to the environmental issues. ${ }^{217}$ These objectives are funded from approximately $€ 351,8$ billion, making cohesion policy consume circa one-third of the entire EU sever year's budget ${ }^{218}$ divided across the member states and their NUTS 2 regions. Within this framework, the cohesion policy delivers a boost to the regional development of individual countries. It has operated under this objective since its inception in the current form in the late 1980s when the major principles were established. ${ }^{219}$ Furthermore, the cohesion policy delivers financial assistance through funds that translate into individual operational programmes on a national scale and further into unique projects supporting specific legal entities and their activities. The following chapter addresses this support, as it has been awarded to the relatively new member states of the European Union, focusing on handling solid municipal waste in Poland, Slovakia, and the Czech Republic. The last country named being the main focus.

\subsection{Pre-accession assistance to the Czech Republic}

Within the EU candidacy period and even prior to that period, the Czech Republic was financially supported by the European Union to meet the criteria to become a full-fledged EU member state. The application to access the European Union was presented in early $1996 .{ }^{220}$ Since then, the Czech Republic became the subject of regular reporting on affairs in various fields connected to the future accession. Pre-accession financial assistance was delivered mainly through specific instruments Phare, Sapard and ISPA to assist the country in becoming a new member state. These were the precursors of the cohesion policy funds the Czech Republic would have to deal with in the future as a member state.

The pre-accession assessment of the Czech Republic focused on multiple points, one of them being the environment. Even before the official application to become an EU member state, the Czech Republic, mindful of this particular objective, began implementing the EU acquis in various

\footnotetext{
216 BACHTLER, J., BEGG, I. Cohesion policy after Brexit: The economic, social and institutional challenges. Journal of Social Policy, vol. 46(4), 2017, p. 745-763.

${ }^{217}$ KAH, S. et al. Strategic Coherence of Cohesion Policy: Comparison of the 2007-13 and 2014-20 Programming Periods, 2016. Available on-line at https://pureportal.strath.ac.uk/en/publications/strategic-coherence-ofcohesion-policy-comparison-of-the-2007-13-.

218 PIATTONI, S., POLVERARI, L. Handbook on Cohesion Policy in the EU. Edward Elgar Publishing. 2016, p. 547.

${ }^{219}$ BAILEY, D., PROPRIS, L. De. The 1988 reform of the European Structural Funds: entitlement or empowerment? Journal of European Public Policy, vol. 9(3), 2002, p. 408-428.

${ }^{220}$ EUROPEAN COMMISSION. Agenda 2000 - Commission Opinion on the Czech Republic's Application for Membership of the European Union, 1997. Available on-line at https://ec.europa.eu/commission/presscorner/detail/en/DOC_97_17.
} 
areas, including the environmental one. However, the Union environmental acquis is vast, ${ }^{221}$ and its implementation has been a multiannual process that would not finish with the country's accession to the European Union.

A closer look at EU perception of the state of the environment in the Czech Republic during the pre-accession period is warranted to understand the magnitude of bringing the Czech Republic up to date with the environmental practices and acquis of the European Union. In the opinion on the Czech membership application, the Commission itself stated significant environmental problems of institutional nature (insufficient legislation and policies) and factual nature (air pollution, existence of hazardous landfills, water pollution). ${ }^{222}$ At the same time, the country's success in improving the environmental situation was noted in improving air quality or decrease in water pollution compared to the 1980s and early 1990s. ${ }^{223}$ The trajectory of improvement was well established, nevertheless not finished and expensive for a country partially still in economic transition. The price of EU membership in adhering to its environmental regulation has been estimated by multiple institutions, including the country itself. It ranged from $€ 9$ billion estimated by the Czech Republic in 2002 to $€ 14,4$ billion estimated by the European Commission. ${ }^{224}$ The investments of cohesion policy and its precursor, pre-accession assistance, would provide much needed financial aid.

The pre-accession assistance to the Czech Republic was delivered by three separate instruments as indicated prior: Phare, an acronym of Poland and Hungary: Aid for the Restructuring of Economies), together with ISPA (Instrument for Structural Policies for Pre-Accession), and SAPARD (Special Action Programme for Pre-accession Aid for Agriculture).

First, and most important of these in terms of assistance, was the Phare programme, which the Czech Republic could use already in 1990 (then as Czechoslovakia). Still, its focus was sharply diverted to accession goals from 1998, with both national and cross-border components present. ${ }^{225}$ Since 1998, annual national Phare funded programmes were implemented in the Czech Republic with the dual role of preparation for the structural policies and preparation for the membership in the EU. Almost every annual programme included project fiches focused on the environment. This funding continued until 2006. In the last two years, it served as a transition facility for the Czech Republic to implement and enforce the acquis and exchange experience. ${ }^{226}$ The following table lists the project fiches related to the field of environment in the period $1998-2006$. The focus on solid municipal waste is evident in 2000, 2002 and 2006 project fiches.

221 BAILEY, I. New Environmental Policy Instruments in the European Union. Routledge, 2017, p. 234; DAVIES, P.G.G. European Union Environmental Law: An Introduction to Key Selected Issues [online] Routledge, 2017, p. 328.

${ }^{222}$ EUROPEAN COMMISSION, Agenda 2000 - Commission Opinion on the Czech Republic's Application for Membership of the European Union, 1997. Available on-line at https://ec.europa.eu/commission/presscorner/detail/en/DOC_97_17.

223 OECD. Environmental Performance Reviews Czech Republic Organisation for Economic Co-Operation and Development, 1999. Available on-line at https://www.oecd-ilibrary.org/docserver/9789264172166en.pdf?expires $=1593435647 \&$ id $=$ id $\&$ accname $=$ ocid41017442\&checksum $=4503640584$ A30C 31649910856 DA37641

224 DIRECTORATE-GENERAL FOR RESEARCH. The Environmental Situation in the Czech Republic, 2003. Available on-line at https://www.europarl.europa.eu/RegData/etudes/note/join/2003/323496/DG-4ENVI_NT(2003)323496_EN.pdf.

${ }^{225}$ MAREK, D., BAUN, M. The EU as a regional actor: The case of the Czech Republic. Journal of Common Market Studies, vol. 40(5), 2002, p. 895-919.

${ }^{226}$ EUROPEAN UNION. Treaty of Accession of the Czech Republic, Estonia, Cyprus, Latvia, Lithuania, Hungary, Malta, Poland, Slovenia and Slovakia, 2003. Available on-line at https://eur-lex.europa.eu/legalcontent/EN/TXT/?uri=CELEX:12003T/TXT. 


\begin{tabular}{|l|l|}
\hline Year & Environment related projects fiches \\
\hline 1998 & $\begin{array}{l}\text { CZ9811: Strengthening the Institutional/Regulatory Capacity in the Environmental } \\
\text { Sector/ Implementation / Investment Strategies for EC Air and Waste Directives }\end{array}$ \\
\hline 2000 & $\begin{array}{l}\text { CZ00.06.01: Implementation Structures for Integrated Pollution Prevention and } \\
\text { Control } \\
\text { CZ00.06.02: Centre for Waste Management }\end{array}$ \\
\hline 2002 & $\begin{array}{l}\text { CZ01.06.01: Equipment for the Monitoring of Air Pollutants (96/62/EC et al) } \\
\text { CZ01.06.02: Implementation of Water Framework Directive } \\
282.06 .02 \text { Environmental Impact Assessment } \\
282.06 .03 \text { Natura 2000 } \\
\text { 282.06.04 Waste Management Centre } \\
282.06 .05 \text { IPPC Implementation } \\
282.06 .06 \text { Environment Sector - Financial Tools }\end{array}$ \\
\hline 2003 & $\begin{array}{l}\text { CZ2003/004-338.04.01 Integrated and Planned Enforcement of Environmental } \\
\text { Law } \\
\text { CZ2003/004-338.04.02 Environmental Information and Management System } \\
\text { (CENIA) }\end{array}$ \\
\hline 2005 & $\begin{array}{l}\text { 2004-006-237-05 Protection of the Ozone Layer EC legislation } \\
\text { 2006/017-518-03.01 - Environment } \\
\mathbf{2 0 0 6 / 0 1 8 - 1 8 2 . 0 4 . 0 3 ~ - ~ I n t e g r a t e d ~ A p p r o a c h ~ t o ~ t h e ~ R e g i o n a l ~ W a s t e ~} \\
\text { Management }\end{array}$ \\
\hline 2004
\end{tabular}

These activities focused on establishing the necessary institutions to apply and enforce environmental acquis in the Czech Republic, first on the national level, later on the regional level. Other instruments also delivered pre-accession aid related to the environment and directly to solid municipal waste management in the Czech Republic. For example, ISPA (The Instrument for Structural Policies Pre-Accession) funded the physical construction of new facilities to incinerate communal waste in the second largest city of Brno.

227 EUROPEAN COMMISSION. PHARE Financing Memoranda \& Project Fiches, 2016. Available on-line at https://ec.europa.eu/neighbourhood-enlargement/instruments/former-assistance/phare_en. 


\subsection{Contribution to the Member States: Czech Republic}

\subsubsection{Assistance to the Czech Republic in 2004-2006}

While the financial assistance to the Czech Republic in the pre-accession period was substantial, as a member state since May $1^{\text {st }}, 2004$, the country gained access to the structural policies of the European Union. These provided even more significant financial resources to tackle a broad selection of problems, including environmentally related issues and those directly connected to the handling of solid municipal waste.

The shortened programming period of 2004-2006, the first one for the Czech Republic as a member state, brought substantial investments into regions to handle the solid municipal waste. The Operational Programme Infrastructure tackled the issue. The programme was divided into two separate parts, Environment and Transport. They were inevitably related by priority focus on mitigating the negative influence of transport on the environment. The environmental part was then further divided into four measures, with "Waste handling and rehabilitation of old polluted sites" being the most interesting one from the point of view of this publication.

Table 2: Operational Programme Infrastructure priorities228

\begin{tabular}{|l|r|}
\hline Priority (measure) & Allocation (EUR) \\
\hline $\begin{array}{l}\text { Modernisation and development of transport infrastructure of national } \\
\text { importance }\end{array}$ & 84070218 \\
\hline Reducing the negative environmental impacts of transport & 14835455 \\
\hline Environmental infrastructure improvement & 142092754 \\
\hline$\quad \begin{array}{l}\text { Measure: recovering the environmental functions of the } \\
\text { landscape }\end{array}$ & - \\
\hline - Measure: Improving infrastructure for water management & - \\
\hline - Measure: Improving infrastructure for air protection & 5361928 \\
\hline Technical assistance & \\
\hline
\end{tabular}

The measure titled Waste handling and rehabilitation of old polluted sites provided finance that could be used to build systems for waste collection, separation, and deal with older areas affected by pollution. ${ }^{22}$ These were often landfills with a significant share of solid municipal waste of various composition that were improperly handled in the past and prone to further biological processes that would require rehabilitation of these sites. ${ }^{230}$

With more than $€ 142$ mil., the operational programme was implemented during the shortened programming period and generated 57 individual projects in the specific measure Waste handling and rehabilitation of old polluted sites. Forty-eight of them handled at least partially solid municipal waste issues. The projects varied greatly in scope in terms of the financial assistance required and the territory they affected. The smallest of them typically dealt with a single municipality and improvements in collecting and separating waste. The largest were either focused on providing

${ }^{228}$ MINISTRY OF TRANSPORT OF THE CZECH REPUBLIC. Operational Programme Infrastructure, 2003.

${ }^{229}$ Ibid.

${ }^{230}$ KUDRNA, Z. Long-term deformations of municipal landfill bodies and their effects on functional safety of superficial sealing. Acta Geodynamica et Geomaterialia, vol. 6(4), 2009, p. 465-473. 
SMW handling systems for broader territories or dealing with old polluted sites - landfills. The latter were implemented in relatively small territories, but the nature of the measures taken required substantial finances. Altogether, some $€ 36,16$ mil. was distributed within these 48 projects (counted using the exchange rate of $28,343 \mathrm{CZK}$ to $1 €$ ).

The following figure depicts the projects implemented in individual municipalities in 14 NUTS 3 regions of the Czech Republic. The color range distinguishes between the type of official beneficiaries of the projects, i.e., the entities that applied for and received financial assistance from the cohesion policy. It is apparent that individual municipalities implemented the majority of the projects. Several were executed by microregions (legal persons uniting municipalities frequently to deal with waste management in the shared territory). In two cases, the beneficiaries were the NUTS 3 regions themselves. In one case, a civil association represented the official beneficiary. In this first period, when the Czech Republic was eligible to use structural policies of the EU, the administration of the projects was a novel occurrence to the beneficiaries who often lacked experience and human resources to deal with the administration as required by the policy rules. This issue remains especially true for smaller beneficiaries such as individual municipalities with small numbers of inhabitants. Combined with a relatively short programming period (2004-2006), multiple waste management related projects by a single beneficiary were an unusual sight. Nevertheless, two municipalities (cities of Dolní Pustevna and Žamberk) successfully applied for two projects each. Doing so gave a significant boost to the solid municipal waste management systems in their territories.

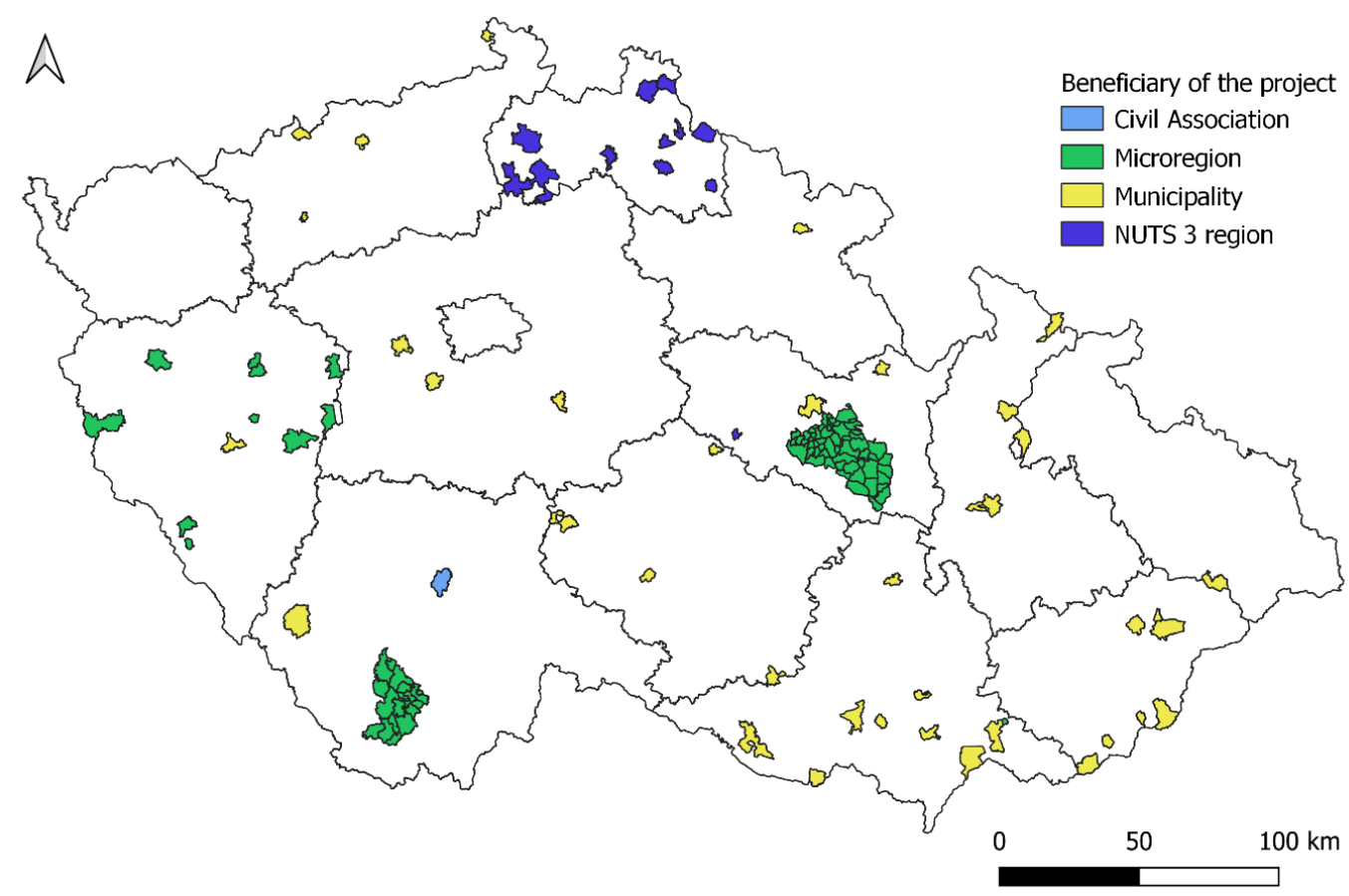

${ }^{231}$ MINISTRY OF REGIONAL DEVELOPMENT OF THE CZECH REPUBLIC. Výsledky čerpání; Programming period 2004-2006, 2021. Available on-line at https://www.dotaceeu.cz/cs/evropske-fondy-vcr/programove-obdobi-2004-2006-(1)/vysledky-cerpani.

232 ArcČR, STATE ADMINISTRATION OF LAND SURVEYING AND CADASTRE, CZECH STATISTICAL OFFICE. Digital Geographic Database ARC ČR 500, 2013. Available on-line at http://www.arcdata.cz/produkty/geograficka-data/arccr-500. 
Topically, the projects were few to be relatively cohesive. A major part of the allocation, approximately $€ 15,5$ mil., was used to boost the number of new facilities collecting the solid municipal waste in municipalities and buy the necessary equipment, which was also the majority of approved projects. The second-largest sum was allocated to landfill recultivation, amounting to $€ 12,9$ mil. Systemic projects focused on providing the territories with comprehensive systems of solid municipal waste handling. They provided new facilities, improved existing facilities, and acquired mobile equipment for SMW collection, focusing on waste sorting.

Table 3: Project types in Czech Republic, programming period 2004 - 2006233

\begin{tabular}{|l|r|r|r|r|}
\hline Project topic & $\begin{array}{r}\text { Total sum in } \\
\text { thousands of } €\end{array}$ & $\begin{array}{r}\text { EU } \\
\text { contribution in } \\
\text { thousands of } €\end{array}$ & $\begin{array}{r}\text { EU } \\
\text { contribution in } \\
\%\end{array}$ & $\begin{array}{r}\text { Number of } \\
\text { projects }\end{array}$ \\
\hline Biodegradable waste handling & 1718 & 1288 & $75 \%$ & 3 \\
\hline New facilities & 15535 & 11651 & $75 \%$ & 23 \\
\hline Landfill recultivation & 12893 & 9453 & $73 \%$ & 15 \\
\hline Systemic projects & 5013 & 3760 & $75 \%$ & 7 \\
\hline
\end{tabular}

This period is characterized by a broad scope of projects, which were primarily aimed at solid municipal waste as a whole. They emphasized the necessity of sorting solid municipal waste into components of further use (mostly plastic, glass, paper waste, and hazardous waste). Few projects were explicitly aimed at providing the opportunity to sort biodegradable waste apart from other types.

The programming period 2004-2006 was relatively short from the new member states such as the Czech Republic. Accordingly, the resources were limited, as was the time to implement individual projects. Nevertheless, this period provided beneficiaries with significant experience aside from the apparent acquirement of financial support for their projects. The experience also served as an example to other potential beneficiaries for the following programming period.

\section{Best practice: Landfill reclamation}

Landfill reclamation projects usually dealt with tips started before appropriate legislation was in place to give exacting conditions for safe and secure operation of landfills. Majority of landfills had issues with present of hazardous waste, contaminated water and gas leakage. The project "Reclamation of Hoštálková landfill" dealt with landfill containing solid domestic waste, including hazardous waste. It included removing of soil overlay and hazardous waste, and finally biological reclamation of the terrain and safe-guarding monitoring of waste itself and contamination of water. ${ }^{234}$

\footnotetext{
233 MINISTRY OF REGIONAL DEVELOPMENT OF THE CZECH REPUBLIC. Výsledky čerpání; Programming period 2004-2006, 2021. Available on-line at https://www.dotaceeu.cz/cs/evropske-fondy-vcr/programove-obdobi-2004-2006-(1)/vysledky-cerpani.

${ }^{234}$ HOŠŤÁLKOVÁ MUNICIPALITY. Zahájení akce Rekultivace skládky TKO Fučínov, 2008. Available on-line at http://www.hostalkova.cz/e_download.php?file=data/uredni_deska/obsah366_1.pdf\&original=TiskZpr_Fuc.pdf; MINISTRY OF REGIONAL DEVELOPMENT OF THE CZECH REPUBLIC. Rekultivace skládky TKO Fučínov, 2020. Available on-line at https://www.dotaceeu.cz/cs/statistiky-a-analyzy/mapa-projektu/projekty-predrokem-2014/2-op-zivotni-prostredi/2-4-zkvalitneni-nakladani-s-odpady-a-odstranovani/rekultivace-skladky-tkofucinov.
} 


\subsubsection{Assistance to the Czech Republic in 2007-2013}

In the programming period 2007-2013, the first one that the Czech Republic spent as a member state its entirety, the European Union Cohesion policy presented a unique chance to change many things and invest in infrastructure, including environmental infrastructure. As did every member state, the Czech Republic had a defining National Strategic Reference Framework that detailed the plan for spending the cohesion policy funding within this period. The document listed brief characteristics of the country with respect to intended investments. Considering the municipal waste, it highlighted its increasing production and the insufficient sorting and use of the sorted solid municipal waste. It also mentioned the unsatisfactory state of some landfills. ${ }^{235}$ Combined with other environmental issues in the Czech Republic and the necessity to implement the Union legislation, the cohesion policy contribution was vested into a single operational programme called Environment. This operational programme had a monetary allocation of $€ 4,64$ bil. from the total amount of cohesion policy contribution of $€ 26,69$ bil. ${ }^{236}$ The amount reflected the enormous tasks at hand.

The programme itself was divided into eight priority axes. Among them, priority axis 4 Improvement of waste handling and removing old ecological burdens mirrored the older Operation programme Infrastructure measures. Municipal and industrial waste handling (both of which may be considered municipal waste to an extent) was allocated more than $€ 515$ mil. Removal of old ecological burdens, including the landfills mentioned in the National Strategic Reference Framework, was allocated more than $€ 197$ mil. $^{237}$

Altogether, 4228 projects were supported within the topics mentioned above-most of those dealing with waste handling, 183 with removing the old ecological burdens.

The internal structure of waste handling projects differs significantly from the previous programming period. In this programming period, the municipalities, municipal enterprises, nonprofit organizations, industrial and agricultural enterprise benefited from waste handling projects. Some of the enterprises specialized in waste handling, including handling solid communal waste (collection, sorting, further use, operation of landfills). Others implemented projects solely to handle the industrial waste produced in the process of their operation. Full or partial relationship to solid municipal waste handling was traceable in 4033 projects amounting to $€ 623,7$ mil., out of which $€ 538,3$ mil. was the EU cohesion policy contribution (counted using the exchange rate of $25,974 \mathrm{CZK}$ to $1 €$, the average exchange rate of the year 2013).

Owing to the more extended programming period and more significant allocation, the composition of projects topics and beneficiaries was rather more diversified in this period. It is divided by the type of waste handled, where possible. The most prominent number of projects and the largest allocation by far was invested in handling biodegradable waste (some of the projects combine handling of household and industrial waste, these were included). This pre-eminence of biodegradable waste-related projects was caused by a new legislature that came into force in 2015 and required that all municipalities provide the citizens with means to dispose of biodegradable waste at least from April to October every year. ${ }^{238}$ These projects aimed to ease the financial burden

\footnotetext{
235 MINISTRY OF REGIONAL DEVELOPMENT OF THE CZECH REPUBLIC. National Strategic Reference Framework of the Czech Republic 2007-2013, 2007. Available on-line at https://dotaceeu.cz/getmedia/316d70b976e1-4152-866d-1671ae735211/NSRR-AJ.pdf.aspx.

236 MINISTRY OF ENVIRONMENT OF THE CZECH REPUBLIC. Programový dokument OPŽP pro období 2007-2013, verze 6, 2015. Available on-line at https://archiv.opzp2007-2013.cz/soubor-ke-stazeni/57/17179pd_opzp_verze_6_schvaleno_ek_27_10_2015.pdf. 237 Ibid. 238 SLAVÍK, J., RYBOVÁ, K., DOLEJŠ, M. Biowaste separation at source and its limitations based on spatial conditions. Detritus, vol. 5(March), 2019, p. 36-45.
} 
to implement the decree of the Ministry of the Environment of the Czech Republic no. 321/2014 on the scope and method of ensuring separate concentration of municipal waste components.

Aside from tackling biodegradable waste and preventing it from being deposited in landfills with other non-sorted solid municipal waste, the most prominent types of waste handled in terms of allocation were construction waste and plastic waste. The projects focused on handing a single type of waste, aside from the biodegradable waste, were less numerous. They represented projects awarded to municipalities and public companies to improve the collection and sorting of the specific waste types. Still, they also included projects awarded to private companies that dealt with further processing of this type of waste.

However, many projects did not focus on a single type of waste that can be part of solid municipal waste but aimed to improve solid municipal waste sorting to use further and prevent amassing in landfills. To this end, the projects supported building new facilities for the collection and sorting of waste and increased the capacity of existing facilities. Some $25 \%$ of the total allocation, amounting to more than $€ 125$ mil., were dedicated to building new places for citizens to bring their waste. Aside from these stationary collection points, the projects categorized as waste handling: sorting improvement focused on bringing the means for sorting physically closer to the citizens. They heavily focused on acquiring new containers to be placed either in public spaces or sometimes in households themselves, making sorting of solid municipal waste more user friendly. These would be then collected from original places or emptied into special trucks and further processed, thus making sorting more accessible and comfortable for the general population and motivating people to sort the solid municipal waste as much as possible with minor inconvenience.

Furthermore, the facilities and municipal waste collecting systems (some contracted to private companies) were financially supported by projects focusing on acquiring new technologies to collect and sort waste (garbage trucks, sorting lines, grinders, pressers, and similar).

The projects present a complex system of solid municipal (and partially industrial) waste handling focused heavily on sorting those components of solid municipal waste that can be of further use. Last but not least, a subgroup of projects was focused on landfill reclamation. Landfills in question certainly included both industrial and solid municipal waste.

Table 4: Project types in Czech Republic, programming period 2007 - 2013239

\begin{tabular}{|c|c|c|c|c|c|}
\hline Project type & Total sum & $\begin{array}{l}\text { EU } \\
\text { contribution } \\
\text { mil. }\end{array}$ & $\begin{array}{l}\% \text { of total } \\
\text { allocation* }\end{array}$ & $\begin{array}{l}\text { Number of } \\
\text { projects }\end{array}$ & $\begin{array}{l}\text { Average } \\
\text { project size in } \\
€ \text { thousands }\end{array}$ \\
\hline $\begin{array}{l}\text { facilities: building new } \\
\text { facilities }\end{array}$ & 98,89 & 83,88 & $15,9 \%$ & 370 & 267 \\
\hline facilities: increasing capacity & 26,99 & 22,08 & $4,3 \%$ & 149 & 181 \\
\hline landfill reclamation & 56,21 & 47,83 & $9,0 \%$ & 81 & 694 \\
\hline new technologies & 22,65 & 19,55 & $3,6 \%$ & 134 & 169 \\
\hline $\begin{array}{l}\text { waste handling: } \\
\text { biodegradable }\end{array}$ & 321,05 & 279,85 & $51,5 \%$ & 2831 & 113 \\
\hline waste handling: construction & 23,40 & 19,91 & $3,8 \%$ & 64 & 366 \\
\hline
\end{tabular}

${ }^{239}$ MINISTRY OF REGIONAL DEVELOPMENT OF THE CZECH REPUBLIC. List of Beneficiaries 02/2017, 2017. Available on-line at https://www.dotaceeu.cz/Dotace/media/SF/Informace o čerpání/Seznamy př́jemců (List of Beneficiaries)/2007-2013/Prehled-prijemcu_v2.xlsx. 


\begin{tabular}{|l|r|r|r|r|r|}
\hline waste handling: electronics & 0,54 & 0,46 & $0,1 \%$ & 2 & 268 \\
\hline waste handling: glass & 11,04 & 10,21 & $1,8 \%$ & 13 & 849 \\
\hline waste handling: metals & 7,19 & 6,13 & $1,2 \%$ & 33 & 218 \\
\hline waste handling: paper & 4,11 & 3,83 & $0,7 \%$ & 28 & 147 \\
\hline $\begin{array}{l}\text { waste handling: plastics } \\
\text { waste handling: textile }\end{array}$ & 20,32 & 18,25 & $3,3 \%$ & 71 & 286 \\
\hline $\begin{array}{l}\text { waste handling: sorting } \\
\text { improvement }\end{array}$ & 1,40 & 1,29 & $0,2 \%$ & 11 & 127 \\
\hline
\end{tabular}

*\% of resources allocated to 4033 analysed projects

\section{Best practice: Sorting improvement}

The project titled "Waste separation and collection system in Kadaň municipality - increase in number of collection points" was one of the typically implemented small projects that focused on acquiring equipment to provide the citizen with new stationary collection points for sorted waste. Similarly, to many such projects, the private company is owned by the municipality and provides, among others, services dealing with collection of waste for households. The investment of this project was used to buy special containers which are then located across the town so that the citizens can deposit the sorted waste relatively close to their households, thus increasing their motivation to sort waste and decrease the volume of unsorted waste from households. No additional fees, apart from municipal waste collection fee, are required.

The support of the cohesion policy was predominantly aimed at the public sector, which implemented more than two-thirds of all the projects, corresponding to approximately $60 \%$ of the total sum spent. Within this category, the vast majority of projects were implemented by municipalities, including municipally founded companies with the status of private legal entity and various legal entities that municipalities use to cooperate. A significant share was awarded to the private sector, as the collection and further processing of the solid municipal waste, including its landfilling, can be contracted to private sector entities. The share of other entities (NGOs, various associations) was negligible. The average size of the project points to smaller projects being implemented by the municipalities. This supports the critique by Horsák and Hřebíček, who early in the programming period pointed out the projects focusing on biodegradable waste implemented by municipalities as rather insufficient to the cause of reducing landfilling of biodegradable waste due to the small volume of waste that could be processed. ${ }^{240}$

240 HORSÁK, Z., HŘEBÍČEK, J. Biodegradable waste management in the Czech Republic. A proposal for improvement. Polish Journal of Environmental Studies, vol. 23(6), 2014, p. 2019-2025. 
Table 5: Applicant types in Czech Republic, programming period 2007 - 2013241

\begin{tabular}{|c|c|c|c|c|c|}
\hline \multirow[t]{2}{*}{ Applicant type } & Total sum & $\begin{array}{l}\text { EU } \\
\text { contribution }\end{array}$ & \multirow[t]{2}{*}{$\begin{array}{l}\% \text { of total } \\
\text { allocation }\end{array}$} & \multirow[t]{2}{*}{$\begin{array}{l}\text { Number of } \\
\text { projects }\end{array}$} & \multirow[t]{2}{*}{$\begin{array}{l}\text { Average project } \\
\text { size in } € \\
\text { thousands }\end{array}$} \\
\hline & \multicolumn{2}{|c|}{ In $€$ mil. } & & & \\
\hline $\begin{array}{l}\text { Public sector institutions } \\
\text { (total) }\end{array}$ & 376,24 & 315,08 & $60,3 \%$ & 2710 & 139 \\
\hline - municipalities & 376,12 & 314,98 & $60,3 \%$ & 2708 & 139 \\
\hline Private profit companies & 242,05 & 218,07 & $38,8 \%$ & 1307 & 185 \\
\hline Others & 5,40 & 5,14 & $0,9 \%$ & 16 & 337 \\
\hline
\end{tabular}

Indeed, the municipalities focused heavily on projects that had to do with sorting, collection, and further processing of biodegradable waste, as the following table shows. These projects were the most numerous. However, their average size was relatively small owing to the inclusion of small municipalities with limited resources for the co-financing. Aside from biodegradable waste handling, the projects focused on improving the number and capacity of waste handling facilities, mainly the collection points for citizens. Many projects also focused on sorting improvement by providing stationary collection containers or other containers to sort and collect sorted waste from households. The largest projects were typically concerned with landfill reclamation.

Table 6: Project types implemented by Crech municipalities, programming period 2007 - 2013242

\begin{tabular}{|l|r|r|r|r|r|}
\hline \multirow{2}{*}{ Project type } & Total sum & $\begin{array}{l}\text { EU } \\
\text { contribution }\end{array}$ & $\begin{array}{l}\text { \% of total } \\
\text { allocation }\end{array}$ & $\begin{array}{l}\text { Number of } \\
\text { projects }\end{array}$ & $\begin{array}{l}\text { Average project } \\
\text { size in } € \\
\text { thousands }\end{array}$ \\
\cline { 2 - 6 } $\begin{array}{l}\text { fn } € \text { mil. } \\
\text { facilitities: building new }\end{array}$ & 91,58 & 77,35 & $24,3 \%$ & 346 & 265 \\
\hline facilities: increasing capacity & 22,08 & 17,67 & $5,9 \%$ & 122 & 181 \\
\hline landfill reclamation & 54,67 & 46,47 & $14,5 \%$ & 75 & 729 \\
\hline new technologies & 7,53 & 6,03 & $2,0 \%$ & 48 & 157 \\
\hline $\begin{array}{l}\text { waste handling: } \\
\text { biodegradable }\end{array}$ & 179,86 & 150,90 & $47,8 \%$ & 1929 & 93 \\
\hline waste handling: construction & 1,02 & 0,87 & $0,3 \%$ & 3 & 341 \\
\hline waste handling: glass & 0,33 & 0,26 & $0,1 \%$ & 4 & 82 \\
\hline waste handling: paper & 0,14 & 0,12 & $0,0 \%$ & 2 & 69 \\
\hline $\begin{array}{l}\text { waste handling: sorting } \\
\text { improvement }\end{array}$ & 18,91 & 15,30 & $5,0 \%$ & 179 & 106 \\
\hline
\end{tabular}

In privately co-financed projects, the focus on biodegradable waste handling was also significant, accounting for more than half of expenditure, reflecting the expected rise in demand for the services from the municipalities. However, outside of this phenomenon, the focus of private companies was more widespread across the various topics, reflecting the inclusion of companies focused on further processing of solid municipal waste of different types.

${ }^{241}$ MINISTRY OF REGIONAL DEVELOPMENT OF THE CZECH REPUBLIC. List of Beneficiaries 02/2017, 2017. Available on-line at https://www.dotaceeu.cz/Dotace/media/SF/Informace o čerpání/Seznamy př́jemců (List of Beneficiaries)/2007-2013/Prehled-prijemcu_v2.xlsx.

242 Ibid. 
Table 7: Project types implemented by Czech private profit companies, programming period 2007 - 2013243

\begin{tabular}{|l|r|r|r|l|r|}
\hline \multirow{2}{*}{ Project type } & Total sum & $\begin{array}{l}\text { EU } \\
\text { contribution }\end{array}$ & $\begin{array}{l}\text { \% of total } \\
\text { allocation }\end{array}$ & $\begin{array}{l}\text { Number of } \\
\text { projects }\end{array}$ & $\begin{array}{l}\text { Average project } \\
\text { size in } € \\
\text { thousands }\end{array}$ \\
\cline { 2 - 7 } $\begin{array}{l}\text { fn } € \text { mil. } \\
\text { facilities: building new }\end{array}$ & 7,32 & 6,53 & $3,0 \%$ & 24 & 305 \\
\hline facilities: increasing capacity & 4,91 & 4,41 & $2,0 \%$ & 27 & 182 \\
\hline landfill reclamation & 1,52 & 1,34 & $0,6 \%$ & 5 & 303 \\
\hline new technologies & 14,96 & 13,36 & $6,2 \%$ & 85 & 176 \\
\hline $\begin{array}{l}\text { waste handling: } \\
\text { biodegradable }\end{array}$ & 135,85 & 123,88 & $56,1 \%$ & 886 & 153 \\
\hline waste handling: construction & 22,38 & 19,04 & $9,2 \%$ & 61 & 367 \\
\hline waste handling: electronics & 0,54 & 0,46 & $0,2 \%$ & 2 & 268 \\
\hline waste handling: glass & 10,72 & 9,94 & $4,4 \%$ & 9 & 1191 \\
\hline waste handling: metals & 7,19 & 6,13 & $3,0 \%$ & 33 & 218 \\
\hline waste handling: paper & 3,97 & 3,71 & $1,6 \%$ & 26 & 153 \\
\hline waste handling: plastics & 20,32 & 18,25 & $8,4 \%$ & 71 & 286 \\
\hline waste handling: textile & 1,40 & 1,29 & $0,6 \%$ & 11 & 127 \\
\hline $\begin{array}{l}\text { waste handling: sorting } \\
\text { improvement }\end{array}$ & 10,98 & 9,73 & $4,5 \%$ & 67 & 164 \\
\hline
\end{tabular}

Given the number of projects, there is little sense to illustrate them on the level of individual municipalities. The situation is further complicated by the inability to assign every project to a single municipality. Some were contracted with private companies who may have offered their services to more municipalities, others with regional public authorities such as NUTS 3 regions or smaller microregions uniting several municipalities. Similarly, many municipalities applied for financial assistance by themselves or as owners of publicly funded enterprises and did so in multiple projects. Due to this constraint, the following figure depicts the allocation per capital in 77 LAU 1 of the Czech Republic, locally known as districts. The method of Jenks breaks was used to divide the LAU 1 districts into five categories according to the allocation per capita of the wasterelated projects obtained in a given district. Thus, the range of support is relatively broad, from 6 $€$ per capita to $184 €$ per capita.

The least supported districts are generally the most prominent cities. Prague district is one of a kind. At the same time, the capital city and a NUTS 2 region with GDP per capita exceeding $75 \%$ of EU NUTS 2 GDP per capita average. Prague was not allocated as substantial resources as other Czech NUTS 2 regions, given its relative advanced development. Other less supported districts include the second, third and fourth-largest cities of the country, respectively, Brno, Pilsen, and Ostrava. Here one can expect that due to the high concentration of population and significant resources available outside of the cohesion policy, the municipal infrastructure to deal with solid municipal waste was already present in adequate quality and quantity. As such, these municipalities had a lesser need to apply for funding. The private companies dealing with waste handling would find the large spaces necessary to process the waste much too expensive in the centres of country settlement and their immediate surroundings. It is then expected they would conduct their business outside of these areas, and thus the funding they obtained would also be located elsewhere. The less supported districts in the northern part of the country include NUTS 3 regional capitals and their immediate surroundings, which may be covered under the same reasoning as populous cities and their immediate background. There is little regularity to the spatial pattern of support to be 
seen other than these less supported areas. Some of the most supported districts, however, show extensive activity in terms of projects numbers. Others attracted multiple large projects, which often have to do with the reclamation of the landfills existing in the territory.

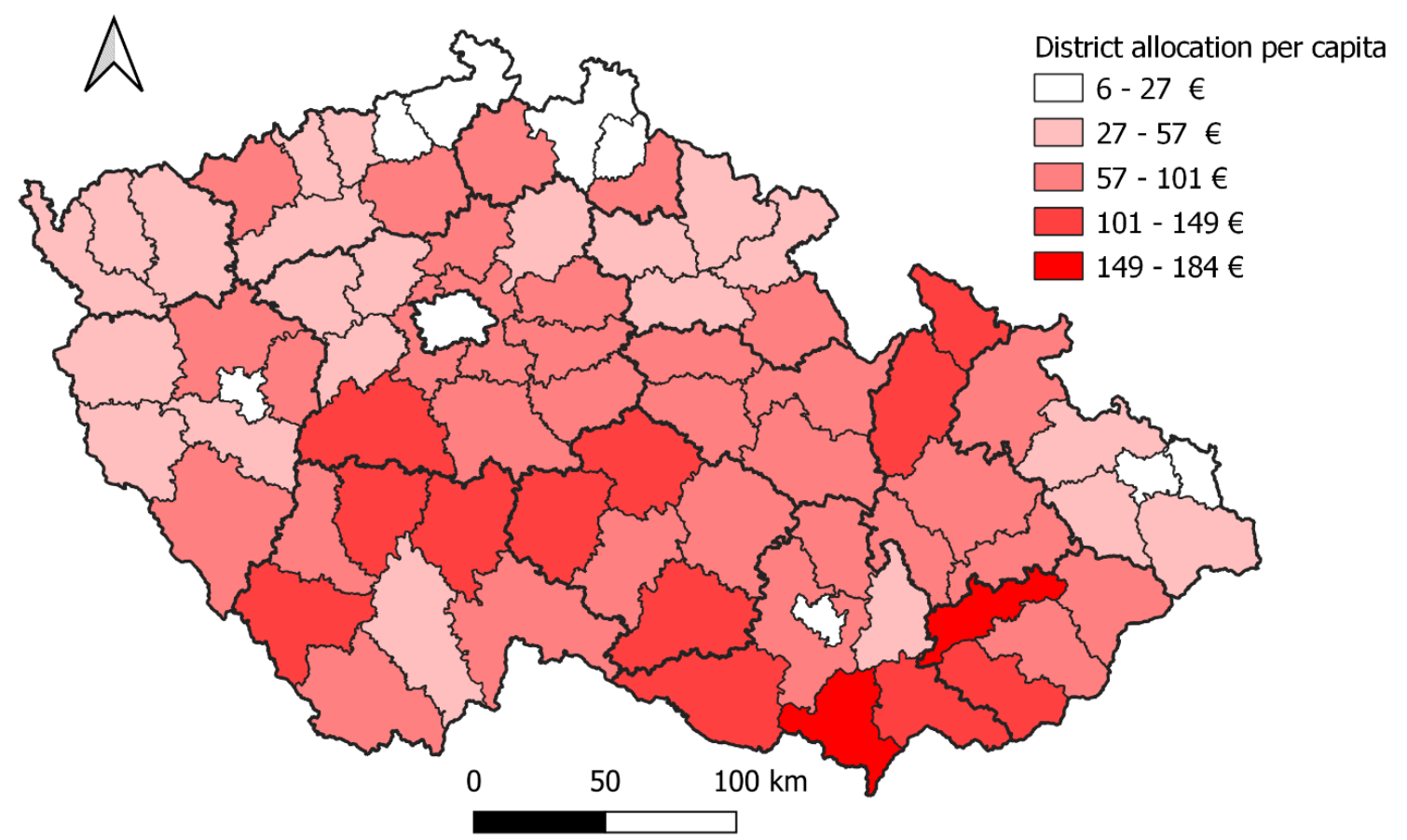

\subsubsection{Assistance to the Czech Republic in 2014-2020}

In the programming period 2014-2020, the environment for the financial support by the cohesion policy changed little in terms of strategic documents governing the spending of allocation. The National Strategic Reference Framework of 2007-2013 was replaced by the Partnership Agreement for the Programming Period 2014-2020, initially approved in August 2014 by the European Commission, which has since been revised five times. The Partnership Agreement, too, included the provisions for Operational Programme Environment, the chief instrument for financing the municipal waste management systems within cohesion policy. The document concluded that while the overall waste production, including the municipal waste produced in the country, decreased and the re-use of waste increased, the solid municipal waste was still predominantly disposed of utilizing landfilling. Landfilling is the least optimal of available disposal methods and included the landfilling of biodegradable waste as a component of solid municipal waste. ${ }^{245}$

To tackle issues of the waste management system, there was again financial assistance to be rendered within the scope of Operational Programme Environment, which was allocated some $€$ 2,8 bil. from $€ 23,8$ bil. available. The programme was divided into six priority axes: the third, Waste management and material flows, environmental burden and risks is of most consequence

244 Ibid.

${ }^{245}$ MINISTRY OF REGIONAL DEVELOPMENT OF THE CZECH REPUBLIC. Partnership Agreement for the Programming Period 2014-2020, Czech Republic, 2019. Available on-line at

https://dotaceeu.cz/getmedia/3e0f0610-a55a-494d-883d-fd80afe90674/Dohoda-o-partnerstvi-(5-revize,-duben2019).pdf.aspx?ext=.pdf. 
to solid municipal waste. It was allocated EU support of $€ 458,8$ mil. This financial support was to be spent on decreasing waste production (both industrial and municipal), door-to-door collection systems, and increasing the further material and energetic use of waste (including support to biodegradable municipal waste sorting and limiting its landfilling), and reclamation of landfills. ${ }^{246}$

A total of 2093 projects were implemented as of July $1^{\text {st }}, 2020$, in this priority axis, with a total allocation of $€ 467,4$ mil. contracted, out of which $€ 359,4$ mil. was acquired from the EU cohesion policy support (exchange rate used for calculation is $25,672 \mathrm{CZK}$ to $1 €$, an average exchange rate of the year 2019). One thousand eight hundred nine projects were found to directly relate to solid municipal waste with investments of $€ 258,40$ mil., out of which $€ 196,31$ was paid for by the cohesion policy. It is necessary to emphasize that unlike the previous period of 2007-2013, the period 2014-2020 still has not finished at the time of this publication. The projects will continue to be implemented until 2023. Thus, the picture presented is not yet entirely complete.

Nevertheless, the typological sorting of the projects presents little change. There was still a strong focus on handling biodegradable waste, emphasising building municipal composting plants and providing citizens with stationary or mobile points for collecting this type of waste. The system of waste collecting facilities was still being improved upon by building new facilities and improving existing ones, particularly their capacity. A new type of facility, however, has emerged, a re-use centre. There were relatively few projects of this type, but they heralded a stricter adherence to the culture of preventing waste production. Landfill reclamation projects were still on the same share of the total sum of investments, including even preliminary surveys in the affected areas. The municipals waste systems were increasingly provided with new technologies to deal more efficiently with waste collection and processing. Sorting improvement, too, saw an increase in the share of investments as the processing of reusable waste produced in households is desirable. On the other hand, the projects aimed at individual types of waste have seen a decline in numbers and investments. The projects usually focused on more than one type of waste (the exception being biodegradable waste). The total sums invested into individual project types were smaller than in the previous period, as the total allocation of the operational programme has decreased. However, it has seen slight increases during the process of updating the Partnership Agreement. While this may seem unfavourable development at large, at the same time, limited resources created a more competitive environment among the projects applicant, which possibly resulted in higher quality projects selected for funding.

Table 8: Project types in Czech Republic, programming period 2014-2020247

\begin{tabular}{|l|r|r|r|l|r|}
\hline \multirow{2}{*}{ Project type } & Total sum & $\begin{array}{l}\text { EU } \\
\text { contribution }\end{array}$ & $\begin{array}{l}\text { \% of total } \\
\text { allocation }\end{array}$ & $\begin{array}{l}\text { Number of } \\
\text { projects }\end{array}$ & $\begin{array}{l}\text { Average project } \\
\text { size in } € \\
\text { thousands }\end{array}$ \\
\cline { 2 - 5 } $\begin{array}{l}\text { In } € \text { mil. } \\
\text { facilities: building new }\end{array}$ & 45,55 & 37,93 & $17,6 \%$ & 195 & 234 \\
\hline$\quad$ reuse facilities & 1,83 & 1,55 & $0,7 \%$ & 14 & 131 \\
\hline facilities: increasing capacity & 9,87 & 7,31 & $3,8 \%$ & 63 & 157 \\
\hline landfill reclamation & 21,07 & 17,91 & $8,2 \%$ & 34 & 620 \\
\hline
\end{tabular}

\footnotetext{
246 MINISTRY OF THE ENVIRONMENT OF THE CZECH REPUBLIC. The Operational Programme Environment 2014-2020 Programming Document, 2019. Available on-line at https://www.opzp.cz/dokumenty/detail/?id=1687.

${ }^{247}$ MINISTRY OF REGIONAL DEVELOPMENT OF THE CZECH REPUBLIC. List of Operations 07/2020, 2020. Available on-line at https://www.dotaceeu.cz/getmedia/416fbafd-bb47-4a56-907c-0033c64226c6/Seznamoperaci-(List-of-operations)-07_2020.xls.aspx?ext=.xls.
} 


\begin{tabular}{|l|r|r|r|r|r|}
\hline new technologies & 24,71 & 11,56 & $9,6 \%$ & 96 & 257 \\
\hline $\begin{array}{l}\text { waste handling: } \\
\text { biodegradable }\end{array}$ & 100,99 & 79,95 & $39,1 \%$ & 868 & 116 \\
\hline $\begin{array}{l}\text { waste handling: other types } \\
\text { of waste }\end{array}$ & 7,29 & 2,79 & $2,8 \%$ & 12 & 608 \\
\hline $\begin{array}{l}\text { waste handling: sorting } \\
\text { improvement }\end{array}$ & 48,92 & 38,85 & $18,9 \%$ & 541 & 90 \\
\hline
\end{tabular}

\section{Best practice: Handling biodegradable waste}

Handling biodegradable waste is essential, as it is a highly undesirable type of waste for landfilling because other biological processes may then start inside the landfills. Therefore, vast amounts have been spent on improving the handling of this type of waste. The projects to do so take several approaches. One of them was selected in Červená Voda, a municipality of some 3 thousand inhabitants. The project "Prevention of biodegradable waste formation in the village of Červená Voda" financed the purchase of 300 compost containers to rent to local households. ${ }^{248}$ These households would then use them for composting biodegradable waste instead of mixing this type of waste with other solid municipal waste.

The municipality of Vlašim, of almost 12 thousand inhabitants, selected a different approach. With funding from the "Acquisition of woodchippers and containers for biowaste for the city of Vlašim" project, the municipality purchased bulk containers into which the citizen could deposit their biodegradable waste. ${ }^{249}$ These would be then collected from stationary points of their location. Both projects included the purchase of woodchippers for biodegradable wood waste. A third approach was taken by Úvaly, a municipality of almost 7 thousand. The municipally owned organization, Technical services of Úvaly Municipality, purchased 1300 bio-dustbins to distribute in the households. ${ }^{250}$ These bins were then collected similarly to regular dustbins, although their contents were exclusively composted, thus reducing unsorted waste.

All projects such as these contribute to improved waste sorting and reduce the amount of biodegradable waste in landfills, as landfilling is still the most common means of unsorted solid municipal waste disposal in the country.

Public sector institutions were once again the primary applicants and beneficiaries of the financial support by cohesion policy. They were chiefly municipalities involved by themselves, represented by municipally owned companies or various types of municipal cooperation platforms. These applicants were responsible for all, but one project awarded to public institutions, reflecting the municipal involvement in managing solid municipal waste. They were awarded more than $83 \%$ of all projects and almost two-thirds of the contracted financial resources. Approximately one-third of funding was allocated to private companies in $16 \%$ of all projects they applied for and were awarded. The involvement of other types of legal entities was negligible.

\footnotetext{
248 MINISTRY OF REGIONAL DEVELOPMENT OF THE CZECH REPUBLIC. Předcházení vzniku biologicky rozložitelných odpadů v území obce Červená Voda, 2020. Available on-line at https://www.dotaceeu.cz/cs/statistiky-a-analyzy/mapa-projektu/projekty/05-operacni-program-zivotniprostredi/05-3-odpady-a-materialove-toky,-ekologicke-zateze/predchazeni-vzniku-biologicky-rozlozitelnych-(20). ${ }^{249}$ MINISTRY OF REGIONAL DEVELOPMENT OF THE CZECH REPUBLIC. Pořízení štěpkovače a kontejnerů na Bioodpad pro město Vlašim?, 2020. Available on-line at https://www.dotaceeu.cz/cs/statistiky-aanalyzy/mapa-projektu/projekty/05-operacni-program-zivotni-prostredi/05-3-odpady-a-materialove-toky,ekologicke-zateze/porizeni-stepkovace-a-kontejneru-na-bioodpad-pro-m.

${ }^{250}$ MINISTRY OF REGIONAL DEVELOPMENT OF THE CZECH REPUBLIC. Poŕízení biopopelnic pro Technické služby města Úvaly, 2020. Available on-line at https://www.dotaceeu.cz/cs/statistiky-a-analyzy/mapaprojektu/projekty/05-operacni-program-zivotni-prostredi/05-3-odpady-a-materialove-toky,-ekologickezateze/porizeni-biopopelnic-pro-technicke-sluzby-mesta-uv.
} 
Table 9: Applicant types in Czech Republic, programming period 2014-2020251

\begin{tabular}{|c|c|c|c|c|c|}
\hline \multirow[t]{2}{*}{ Applicant type } & Total sum & $\begin{array}{l}\text { EU } \\
\text { contribution }\end{array}$ & \multirow[t]{2}{*}{$\begin{array}{l}\% \text { of total } \\
\text { allocation }\end{array}$} & \multirow[t]{2}{*}{$\begin{array}{l}\text { Number of } \\
\text { projects }\end{array}$} & \multirow{2}{*}{$\begin{array}{l}\text { Average project } \\
\text { size in } € \\
\text { thousands }\end{array}$} \\
\hline & \multicolumn{2}{|c|}{ In $€$ mil. } & & & \\
\hline Public sector institutions & 167,93 & 138,29 & $65,0 \%$ & 1512 & 111 \\
\hline Private profit companies & 90,13 & 57,72 & $34,9 \%$ & 291 & 310 \\
\hline Others & 0,34 & 0,29 & $0,1 \%$ & 6 & 57 \\
\hline
\end{tabular}

The projects implemented by municipalities were primarily investing in handling biodegradable waste, although the dominance of this topic was no longer as pronounced. Approximately the same amount of investments was aimed at building new facilities, mainly collection points, and more rarely re-use centres. Almost one-fourth of the investments aimed to sort improvement of various waste types, especially by procuring new door-to-door systems and stationary containers for sorted waste. Of other topics, landfill reclamation recorded a significant share of total municipal investments.

Table 10: Project types implemented by the municipalities in Czech Republic, programming period 2014-2020252

\begin{tabular}{|c|c|c|c|c|c|}
\hline Project type & Total sum & $\begin{array}{l}\text { EU } \\
\text { contribution } \\
\text { mil. }\end{array}$ & $\begin{array}{l}\% \text { of total } \\
\text { allocation }\end{array}$ & $\begin{array}{l}\text { Number of } \\
\text { projects }\end{array}$ & $\begin{array}{l}\text { Average project } \\
\text { size in } € \\
\text { thousands }\end{array}$ \\
\hline $\begin{array}{l}\text { facilities: building new } \\
\text { facilities }\end{array}$ & 43,82 & 37.25 & $26,1 \%$ & 191 & 229 \\
\hline - $\quad$ reuse facilities & 1,64 & 1,39 & $1,0 \%$ & 12 & 137 \\
\hline facilities: increasing capacity & 8,22 & 6,69 & $4,9 \%$ & 59 & 139 \\
\hline landfill reclamation & 20,58 & 17,49 & $12,3 \%$ & 29 & 710 \\
\hline new technologies & 7,78 & 4,45 & $4,6 \%$ & 60 & 130 \\
\hline $\begin{array}{l}\text { waste handling: } \\
\text { biodegradable }\end{array}$ & 47,85 & 40,05 & $28,5 \%$ & 691 & 69 \\
\hline $\begin{array}{l}\text { waste handling: sorting } \\
\text { improvement }\end{array}$ & 39,68 & 32,36 & $23,6 \%$ & 482 & 82 \\
\hline
\end{tabular}

Private for-profit companies remained firmly focused on projects that dealt with biodegradable waste. For the private operations, the programme also served as means of purchasing new technologies. Contracted companies purchased new containers and improved their collection systems for sorted waste. Given that some of these companies specialized in dealing with particular waste type, some of the projects were aimed at handling particular types of waste. The building and increasing of the capacity of private collection points was considerably less frequent than with municipalities, as was the landfill reclamation.

251 MINISTRY OF REGIONAL DEVELOPMENT OF THE CZECH REPUBLIC. List of Operations 07/2020, 2020. Available on-line at https://www.dotaceeu.cz/getmedia/416fbafd-bb47-4a56-907c-0033c64226c6/Seznamoperaci-(List-of-operations)-07_2020.xls.aspx?ext=.xls. 252 Ibid. 
Table 11: Project types implemented by the private companies in Czech Republic, programming period 2014-2020253

\begin{tabular}{|c|c|c|c|c|c|}
\hline \multirow[t]{2}{*}{ Project type } & Total sum & $\begin{array}{l}\text { EU } \\
\text { contribution }\end{array}$ & \multirow[t]{2}{*}{$\begin{array}{l}\% \text { of total } \\
\text { allocation }\end{array}$} & \multirow[t]{2}{*}{$\begin{array}{l}\text { Number of } \\
\text { projects }\end{array}$} & \multirow[t]{2}{*}{$\begin{array}{l}\text { Average project } \\
\text { size in } € \\
\text { thousands }\end{array}$} \\
\hline & \multicolumn{2}{|c|}{ In $€$ mil. } & & & \\
\hline $\begin{array}{l}\text { facilities: building new } \\
\text { facilities }\end{array}$ & 1,68 & 0,64 & $1,9 \%$ & 3 & 560 \\
\hline - reuse facilities & 0,14 & 0,12 & $0,2 \%$ & 1 & 137 \\
\hline facilities: increasing capacity & 1,65 & 0,62 & $1,8 \%$ & 4 & 411 \\
\hline landfill reclamation & 0,34 & 0,29 & $0,4 \%$ & 3 & 114 \\
\hline new technologies & 16,93 & 7,11 & $18,8 \%$ & 36 & 470 \\
\hline $\begin{array}{l}\text { waste handling: } \\
\text { biodegradable }\end{array}$ & 53,10 & 39,87 & $58,9 \%$ & 176 & 302 \\
\hline $\begin{array}{l}\text { waste handling: other types } \\
\text { of waste }\end{array}$ & 7,23 & 2,73 & $8,02 \%$ & 11 & 657 \\
\hline $\begin{array}{l}\text { waste handling: sorting } \\
\text { improvement }\end{array}$ & 9,20 & 6,46 & $10,2 \%$ & 58 & 159 \\
\hline
\end{tabular}

While spatial distribution followed no particular pattern, it was visibly less uniformly distributed than in the previous programming period 2007-2013. Nevertheless, the most supported districts of the Czech Republic had a common trait: building biogas plants rather than landfill reclamation, which only emerges as an important project in less supported regions. Biogas plants represented means to dispose of biodegradable waste. These large installations serviced wider regions, and due to the occasional smells that might emerge, they are best built outside of highly populated areas.

Figure 17: Investments per capita in Czech LAU 1; 2014-2020 programming period254

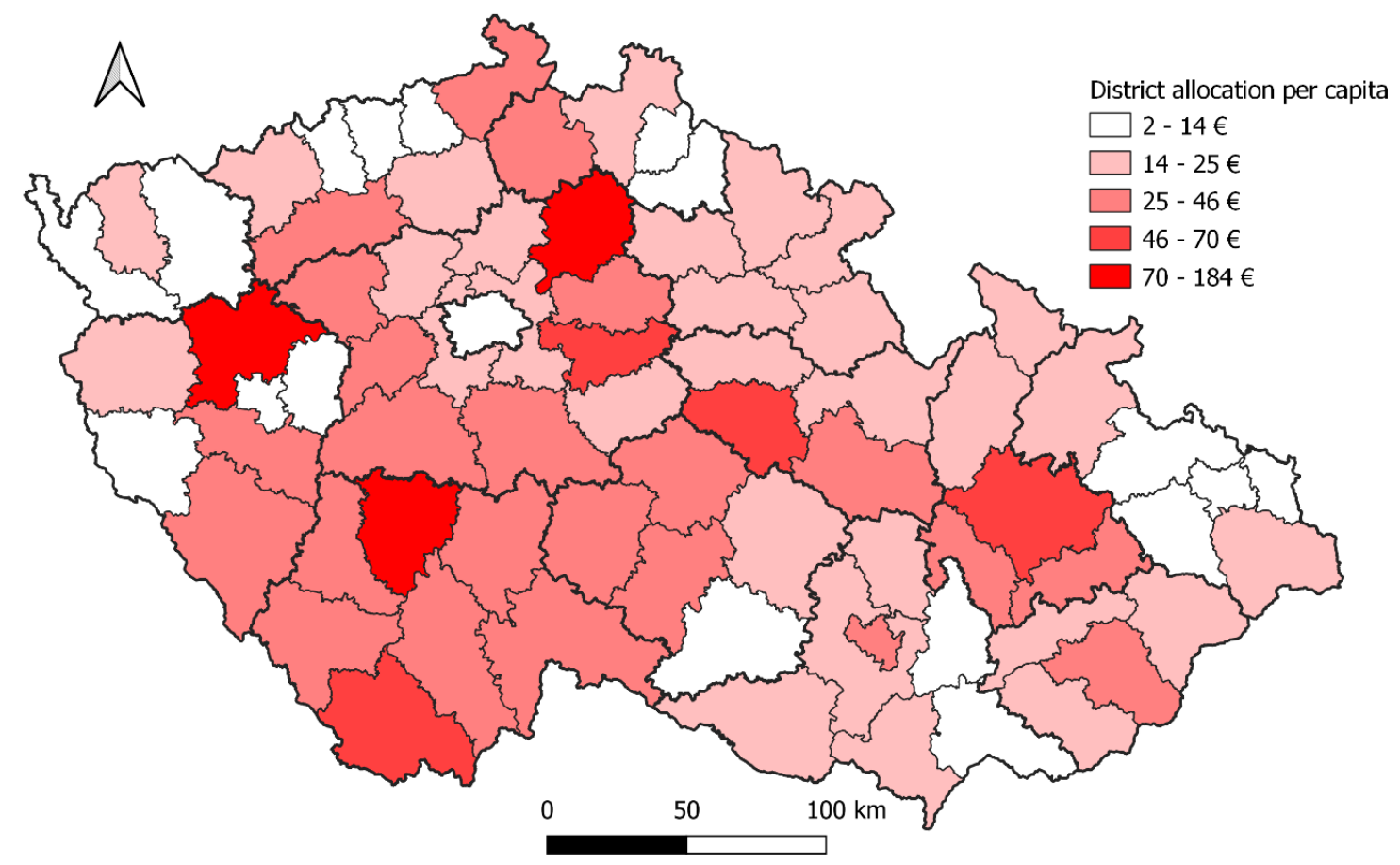

253 Ibid.

254 Ibid. 


\subsection{Contribution to the Member States: Poland}

\subsubsection{Assistance to Poland in 2007-2013}

In the period 2007-2013, Poland recorded a somewhat different approach than the Czech Republic did. In the National Strategic Reference Framework, Poland also noted issues connected to the handling of solid municipal waste, although the amount of municipal waste, in general, was slowly declining. Therefore, a focus on measures addressing low waste utilization (both municipal and industrial) and the overabundance of landfilling the municipal waste was proposed in the document. ${ }^{255}$ These measures were then embedded in Operational Programme Infrastructure and Environment and in the regional operational programmes of which Poland had 16, each for one of the Polish voivodeships, corresponding to NUTS 2 units.

The Operational Programme Infrastructure and Environment 2007-2013 was allocated $€ 28337$ mil. from the European Regional Development Fund and Cohesion Fund combined. It contained 15 priority axes on account of being focused on a relatively broad spectrum of activities and issues. Second priority axis Waste management and the protection of Earth dealt closely with issues of solid municipal waste. The document estimated that $95 \%$ of municipal waste was landfilled, $48 \%$ of municipal waste was a biodegradable waste, and little of all waste types were sorted. It also asserted that many landfills were not adequately secured. ${ }^{256}$

The second priority axis proclaimed the objectives of landfill reclamation, reducing the amount of landfilled municipal waste, which should be instead recycled or disposed of by other means and eliminating risks stemming from waste disposals - landfilling, in other words. The other methods of disposing of waste included incineration, especially in large agglomerations of Poland. The programme focused on supporting particular companies, "zakład zagospodarowania odpadów" (literal translation "waste management facility"), devoted to waste management in areas populated by 150 thousand or more inhabitants. These should offer complex services of storage, utilisation, sorting, incineration, composting, even landfilling if necessary. For agglomerations exceeding 300 thousand, the method of incineration was preferred to dispose of mixed municipal waste. ${ }^{257}$ To this end, the priority axis had an allocation of approximately $€ 1027$ mil.

The approach to individual projects was much different than in the Czech Republic. Within this priority axis, 83 projects dealt with SMW. They amounted to a total amount of approximately $€ 1$ 899 mil., the contribution of the EU to this investment was $€ 867,2$ mil. (from now on calculated using the exchange rate of 4,197 PLN to $1 €$, the average exchange rate of 2013). ${ }^{258}$ Unlike in the Czech Republic, these projects were fewer, financially more demanding, and more complex. They focused on providing infrastructure for complex waste management within a given territory. A typical project aimed to improve or create a waste management facility described above in the objectives of the priority axis. There was no diving the projects into single topics, as multiple were covered inside single action that often spanned quite a large area. The topic, if assigned, would be in many cases similar to those implemented in the Czech Republic, albeit through multiple projects. The Polish projects provided facilities to store, sort waste, compost the biodegradable

\footnotetext{
${ }^{255}$ MINISTRY OF REGIONAL DEVELOPMENT OF POLAND. Poland National Strategic Reference Framework 2007-2013, 2007. Available on-line at www.mrr.gov.pl. 256 MINISTRY OF REGIONAL DEVELOPMENT OF POLAND. Program operacyjny Infrastruktura $i$ środowisko 2007-2013, wersja 5, 2016. Available on-line at https:/ /www.pois.20072013.gov.pl/Dokumenty/Documents/POIS_2007_2013_wersja_5_0.pdf. 257 Ibid.

${ }^{258}$ EUROPEAN CENTRAL BANK. ECB euro reference exchange rate: Polish zloty (PLN), 2020. Available online at https://www.ecb.europa.eu/stats/policy_and_exchange_rates/euro_reference_exchange_rates/html/eurofxrefgraph-pln.en.html.
} 
waste, and other activities. Unlike in the Czech Republic, there was also significant action of building incinerators for municipal waste.

\section{Best practice: Projects in 2007-2013 programming period in Poland}

One of the showcase projects that sums up the efforts undertaken by various projects in order to improve the state of waste management systems across the country is the "Construction of a municipal waste disposal plant with a landfill site in Siedliska near Ełk" featured in 2012 brochure on the changes made possible by investments of the Operational Programme Infrastructure and Environment 2007-2013. ${ }^{259}$ This project invested into a new facility to collect and sort waste for 12 Polish gminas (municipalitie) in Warmińsko-Mazurskie Voivodeship.

Figure 18: New facility in Siedliska near Etk260

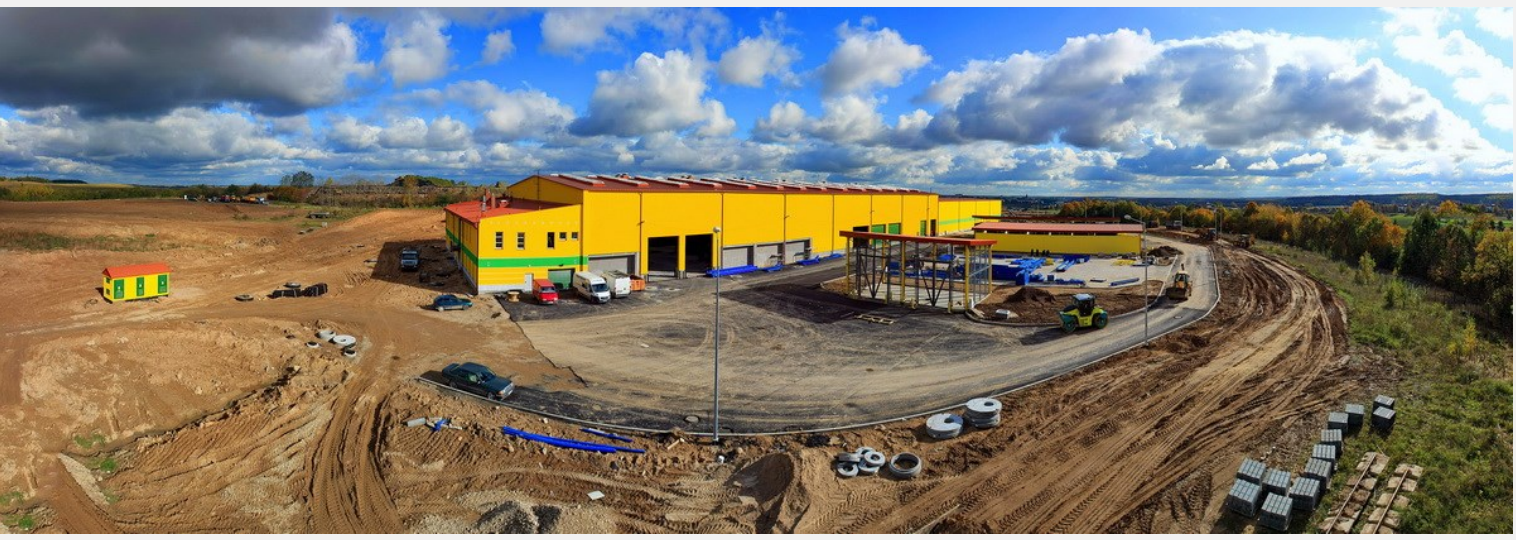

Aside from the projects implemented within the Operational Programme Infrastructure and Environment 2007-2013, projects related to solid municipal waste were also implemented within 16 regional operational programmes of Polish voivodeships. Some of which had a very similar description of building waste management facilities and carrying out landfill reclamation. Others remained somewhat vague with notions on promoting recycling and further use of waste. Nevertheless, every regional operational programme of Polish NUTS 2 voivodeships included a priority axis concerned with solid municipal waste, as evidenced by the following table. The share of such priority axis on the total allocation of the programme ranged from $6 \%$ to $16 \%$. However, it is necessary to note that these priority axes were more broadly oriented. They also dealt with wastewater, air pollution, energy consumption, and other issues.

\footnotetext{
${ }^{259}$ MINISTRY OF REGIONAL DEVELOPMENT OF POLAND. European Funds See changes in progress, 2012. Available on-line at https://www.pois.2007-

2013.gov.pl/dzialaniapromocyjne/Documents/Folder_ENG_29112012.pdf.

260 PRZEDSIĘBIORSTWO GOSPODARKI ODPADAMI EKO-MAZURY. Budowa Zakładu Unieszkodliwiania Odpadów w Siedliskach k/Ełku, 2019. Available on-line at http://eko-mazury.elk.pl/inwestycje-projekty/budowazakladu-unieszkodliwiania-odpadow-w-siedliskach-k-elku/.
} 
Table 12: Regional Operational Programmes in Poland, 2007-2013 programming period

\begin{tabular}{|c|c|c|c|}
\hline Programme & Priority axis & $\begin{array}{ll}\text { Allocation } & \text { of } \\
\text { Programme } & (€ \\
\text { mil.) } & \\
\end{array}$ & $\begin{array}{l}\text { Allocation of } \\
\text { Priority axis }\end{array}$ \\
\hline $\begin{array}{l}\text { Operational Programme } \\
\text { 'Lower Silesia'261 }\end{array}$ & $\begin{array}{l}\text { Improvement of the natural } \\
\text { environment and } \\
\text { improvement of ecological } \\
\text { and flood safety in Lower } \\
\text { Silesia }\end{array}$ & 1213 & 128,7 \\
\hline $\begin{array}{l}\text { Operational Programme } \\
\text { 'Zachodniopomorskie'262 }\end{array}$ & $\begin{array}{l}\text { Infrastructure of environmental } \\
\text { protection }\end{array}$ & 862 & 61,3 \\
\hline $\begin{array}{l}\text { Operational programme } \\
\text { 'Greater Poland'263 }\end{array}$ & Environment & 1332 & 173,8 \\
\hline $\begin{array}{l}\text { Operational Programme } \\
\text { 'Warminsko-Mazurskie'264 }\end{array}$ & Nature environment & 1070 & 93,3 \\
\hline $\begin{array}{l}\text { Operational Programme } \\
\text { 'Podlaskie'265 }\end{array}$ & $\begin{array}{l}\text { Development of infrastructure for } \\
\text { environment protection }\end{array}$ & 672 & 50,9 \\
\hline $\begin{array}{l}\text { Operational Programme } \\
\text { 'Kujawsko-Pomorskie'266 }\end{array}$ & $\begin{array}{l}\text { Maintenance and rational } \\
\text { utilization of environment }\end{array}$ & 996 & 117,9 \\
\hline $\begin{array}{l}\text { Operational Programme } \\
\text { 'Mazovia'267 }\end{array}$ & $\begin{array}{l}\text { Environment, prevention of } \\
\text { threats, and energy }\end{array}$ & 1868 & 215,3 \\
\hline $\begin{array}{l}\text { Operational Programme } \\
\text { 'Opolskie'268 }\end{array}$ & Environmental protection & 491 & 49,2 \\
\hline $\begin{array}{l}\text { Operational Programme } \\
\text { 'Lubelskie'269 }\end{array}$ & Environment and clean energy & 1155 & 156,0 \\
\hline $\begin{array}{l}\text { Operational Programme } \\
\text { 'Silesia'270 }\end{array}$ & Environment & 1712 & 180,7 \\
\hline
\end{tabular}

261 ZARZĄD WOJEWÓDZTWA DOLNOŚLĄSKIEGO. Regional Operational Programme for the Lower Silesian Voivodship, 2007. Available on-line at http://old.rpo.dolnyslask.pl/pliki/ROP_21_08_2007_en.pdf.

262 ZARZĄD WOJEWÓDZTWA ZACHODNIOPOMORSKIEGO. Regionalny Program Operacyjny

Województwa Zachodniopomorskiego na lata 2007-2013, 2016. Available on-line at http://rpo2007-

2013.wzp.pl/rpo/regionalny_program_operacyjny/p-r-m-a-24632/regionalny_program_operacyjny.htm.

263 BOARD OF THE WIELKOPOLSKIE VOIVODSHIP. Wielkopolska Regional Operational Programme For 2007-2013, 2011. Available on-line at http://www.wrot.umww.pl/wp-

content/uploads/2014/08/WRPO_8_1_eng_version.pdf.

${ }^{264}$ ZARZĄD WOJEWÓDZTWA WARMIŃSKO-MAZURSKIEGO. Regionalny Program Operacyjny Warmia i

Mazury na lata 2007-2013, 2012. Available on-line at http://rpo.07-

13.warmia.mazury.pl/index.php?page=dzial\&dzial_id $=79$.

265 URZA_D MARSZAŁKOWSKI WOJEWÓDZTWA PODLASKIEGO. Regionalny Program Operacyjny

Województwa Podlaskiego na lata 2007-2013, 2016. Available on-line at

http://www.rpowp.wrotapodlasia.pl/private/upload/ file/41ad28912948fd45a20eed582cd98395.pdf.

266 BOARD OF KUJAWSKO - POMORSKIE VOIVODESHIP. Regional Operational Programme of Kujawsko-

Pomorskie Voivodeship for the years 2007-2013, 2011. Available on-line at http://2007-

2013.mojregion.eu/tl_files/mojregion/dokumenty-rpo/Wazne dokumenty/Dokumenty programowe/Regional

Operational Programme for K-P Voivodeship-v2-KE wersja ujednolicona grudzien 2011.pdf.

${ }^{267}$ URZADD MARSZAŁKOWSKI WOJEWÓDZTWA MAZOWIECKIEGO. Regionalny program operacyjny

Województwa Mazowieckiego 2007 - 2013, 2011. Available on-line at

http://rpo.mazowia.eu/g2/oryginal/2012_02/1c01ced4116376e42bd66c05eb6d5341.pdf.

268 ZARZĄD WOJEWÓDZTWA OPOLSKIEGO. Regionalny Program Operacyjny Województwa Opolskiego na lata 2007-2013. Available on-line at http://archiwum.opolskie.pl/docs/rpo_wo.pdf.

269 ZARZĄD WOJEWÓDZTWA LUBELSKIEGO. Regionalny Program Operacyjny Województwa Lubelskiego na lata 2007-2013. Available on-line at http://www.lawp.eu/index.php?menu=rpo.

${ }^{270}$ URZAD MARSZAŁKOWSKIEGO WOJEWÓDZTWA ŚLASSKIEGO. Regionalny Program Operacyjny

Województwa Śląskiego na lata 2007 - 2013, 2010. Available on-line at https:/ / rpo2007-

2013.slaskie.pl/zalaczniki/2010/10/07/1286452333.pdf. 


\begin{tabular}{|l|l|r|r|}
\hline $\begin{array}{l}\text { Operational Programme } \\
\text { 'Świętokrzyskie'271 }\end{array}$ & $\begin{array}{l}\text { Development of the } \\
\text { Environmental Protection and } \\
\text { Energy Infrastructure }\end{array}$ & 726 & 101,0 \\
\hline $\begin{array}{l}\text { Operational Programme } \\
\text { 'Lubuskie'272 }\end{array}$ & $\begin{array}{l}\text { Protection and management of the } \\
\text { environment's natural resources }\end{array}$ & 494 & 80,5 \\
\hline $\begin{array}{l}\text { Operational Programme } \\
\text { 'Podkarpackie'273 }\end{array}$ & $\begin{array}{l}\text { Environment Protection and Risk } \\
\text { Prevention }\end{array}$ & 1199 & 170,4 \\
\hline $\begin{array}{l}\text { Operational Programme } \\
\text { 'Pomerania'274 }\end{array}$ & $\begin{array}{l}\text { Environment and environmentally } \\
\text { friendly energy }\end{array}$ & 885 & 53,9 \\
\hline $\begin{array}{l}\text { Operational Programme } \\
\text { 'Lesser Poland'275 }\end{array}$ & $\begin{array}{l}\text { Infrastructure for environmental } \\
\text { protection }\end{array}$ & 1356 & 98,0 \\
\hline $\begin{array}{l}\text { Operational Programme } \\
\text { 'Lódzkie'276 }\end{array}$ & $\begin{array}{l}\text { Environmental protection, } \\
\text { prevention of threats, and energy }\end{array}$ & 1046 & 171,0 \\
\hline
\end{tabular}

The final investments in handling solid municipal waste within individual regional operational programmes of Poland is depicted in the following table. It illustrates different emphasis put on the issues in various NUTS 2 regional operational programmes.

Table 13: Investments into SWM related projects in Polish Regional Operational Programmes, 2007-2013 programming period277

\begin{tabular}{|c|c|c|c|c|}
\hline \multirow[t]{2}{*}{ Operational programme } & $\begin{array}{l}\text { Total } \\
\text { sum }\end{array}$ & $\begin{array}{l}\text { EU } \\
\text { contribution }\end{array}$ & \multirow[t]{2}{*}{$\begin{array}{l}\text { Number of } \\
\text { projects }\end{array}$} & \multirow[t]{2}{*}{$\begin{array}{c}\text { Average } \\
\text { project size in } \\
€ \text { thousands }\end{array}$} \\
\hline & \multicolumn{2}{|c|}{ In $€$ mil. } & & \\
\hline Operational Programme 'Lower Silesia' & 39,21 & 21,88 & 28 & 1400 \\
\hline $\begin{array}{l}\text { Operational Programme } \\
\text { 'Zachodniopomorskie' }\end{array}$ & 7,31 & 3,26 & 20 & 366 \\
\hline Operational programme 'Greater Poland' & 29,74 & 16,20 & 2 & 14871 \\
\hline $\begin{array}{l}\text { Operational Programme 'Warminsko- } \\
\text { Mazurskie' }\end{array}$ & 21,80 & 9,60 & 17 & 1283 \\
\hline Operational Programme 'Podlaskie' & 5,74 & 4,50 & 18 & 319 \\
\hline $\begin{array}{l}\text { Operational Programme 'Kujawsko- } \\
\text { Pomorskie' }\end{array}$ & 41,40 & 16,23 & 13 & 3185 \\
\hline
\end{tabular}

271 ZARZĄD WOJEWÓDZTWA ŚWIĘTOKRZYSKIEGO. Szczegółowy opis osi priorytetowych Regionalnego Programu Operacyjnego Województwa Świętokrzyskiego na lata 2007 - 2013, 2009. Available on-line at https://www.funduszeeuropejskie.2007-

2013.gov.pl/dokumenty/zmianywdokumentach/documents/uszczegolowienie_rpo_swietokrzyskie_11_09.pdf. 272 ZARZALD WOJEWÓDZTWA LUBUSKIEGO. Lubuski Regionalny Program Operacyjny na lata 2007-2013, 2011. Available on-line at

http:/ /www.lrpo.lubuskie.pl/index.php?option=com_content\&view=category\&layout=blog\&id=80\&Itemid=151. 273 ZARZA_D WOJEWÓDZTWA PODKARPACKIEGO. Regionalny Program Operacyjny Województwa

Podkarpackiego na lata 2007-2013, 2012. Available on-line at http://rpo2007-

2013.podkarpackie.pl/pliki/file/Dokumenty Programowe/RPO/zaktual_rpo_wp_12_2011.pdf.

274 ZARZĄD WOJEWÓDZTWA POMORSKIEGO. Regionalny Program Operacyjny dla Województwa

Pomorskiego na lata 2007-2013, 2010. Available on-line at https://www.arp.gda.pl/plik,3111,regionalny-programoperacyjny-dla-wojewodztwa-pomorskiego-na-lata-2007-2013-rpo-wp-2007-2013-wrzesien-2010.pdf.

275 ZARZĄD WOJEWÓDZTWA MALOPOLSKIEGO. Małopolski Regionalny Program Operacyjny na lata 2007-2013, 2016. Available on-line at

http://www.fundusze20072013.malopolska.pl/mrpo/Documents/dokumenty-programowe/MRPO_6122016.pdf. ${ }^{276}$ MINISTERSTWO FUNDUSZY I POLITYKI REGIONALNEJ. Regionalny Program Województwa

Łódzkiego, 2012. Available on-line at https://www.funduszeeuropejskie.2007-

2013.gov.pl/rpo/strony/rpo_lodzkie.aspx.

277 MINISTERSTWO FUNDUSZY I POLITYKI REGIONALNEJ. Lista beneficjentów Funduszy Europejskich 2007-2013 - stan na 31 grudnia 2018 r, 2019. Available on-line at https://www.funduszeeuropejskie.2007-

2013.gov.pl/NaborWnioskow/listabeneficjentow/Strony/Lista_beneficjentow_FE_31122018.aspx. 


\begin{tabular}{|l|r|r|r|r|}
\hline Operational Programme 'Mazovia' & 21,91 & 10,59 & 19 & 1153 \\
\hline Operational Programme 'Opolskie' & 1,59 & 0,90 & 5 & 317 \\
\hline Operational Programme 'Lubelskie' & 42,63 & 28,04 & 13 & 3279 \\
\hline Operational Programme 'Silesia' & 27,76 & 17,53 & 21 & 1322 \\
\hline Operational Programme 'Świętokrzyskie' & 6,57 & 2,66 & 2 & 3284 \\
\hline Operational Programme 'Lubuskie' & 1,43 & 1,22 & 1 & 1433 \\
\hline Operational Programme 'Podkarpackie' & 8,67 & 5,93 & 14 & 619 \\
\hline Operational Programme 'Pomerania' & 26,87 & 11,34 & 9 & 2985 \\
\hline Operational Programme 'Lesser Poland' & 9,92 & 6,78 & 15 & 661 \\
\hline Operational Programme 'Lódzkie' & 11,62 & 7,65 & 13 & 894 \\
\hline
\end{tabular}

The regional operational programmes funded 210 projects across all 16 NUTS 2 worth $€ 304$ mil., $€ 164$ mil. was funded by the cohesion policy. The topics of these projects were more focused on landfill reclamation and included some projects of a less complex nature with regards to waste management of municipal waste. However, compared to the Czech Republic, these projects were still combining treatments of waste municipal waste, sorting the waste, acquiring new technologies to collect and treat waste, with landfill reclamation and special provisions for biodegradable waste.

Public institutions were the primary beneficiaries across all operational programmes that dealt with solid municipal waste, whether in terms of the total number of projects or the amount invested. Municipalities and municipal associations alone spent more than half of the total allocation.

Table 14: Types of applicants across all Polish regional operational programmes and the national operational programme, 2007-2013 programming period 278

\begin{tabular}{|l|r|r|r|r|r|}
\hline \multirow{2}{*}{ Applicant type } & Total sum & $\begin{array}{l}\text { EU } \\
\text { contribution }\end{array}$ & $\begin{array}{l}\text { \% of total } \\
\text { allocation }\end{array}$ & $\begin{array}{l}\text { Number of } \\
\text { projects }\end{array}$ & $\begin{array}{l}\text { Average project } \\
\text { size in } € \\
\text { thousands }\end{array}$ \\
\cline { 2 - 6 } & \multicolumn{2}{|c|}{ In $€$ mil. } & & 267 & 7122 \\
\hline $\begin{array}{l}\text { Public sector institutions } \\
\text { (total) }\end{array}$ & 1901,61 & 929,06 & $86,3 \%$ & 219 & 5378 \\
\hline$-\quad$ municipalities & 1177,75 & 574,34 & $53,5 \%$ & 26 & 11605 \\
\hline Private profit companies & 301,74 & 102,47 & $13,7 \%$ & \\
\hline
\end{tabular}

Spatial distribution of the allocation across all operational programmes is depicted on LAU 1 level of powiats and cities with powiat status. Approximately $3 \%$ of the entire allocation is not depicted due to being implemented in larger areas than LAU 1. While the majority of LAU 1 units received some amount of support, approximately one third received none. The most significant amounts invested concentrated especially in large agglomerations due to activities financed from the national Operational Programme Infrastructure and Environment that supported the improvement of waste management systems in cities, including building waste incineration facilities. However, the following picture shows the per capita support in LAU 1, highlighting concentration in Zachodniopomorskie NUTS 2 in the Polish northwest and Podlaskie NUTS 2 in the northeast. In central and southern parts of the country, where the per capita support is less evenly dispersed, the large administrative capitals often received substantial support.

278 Ibid. 


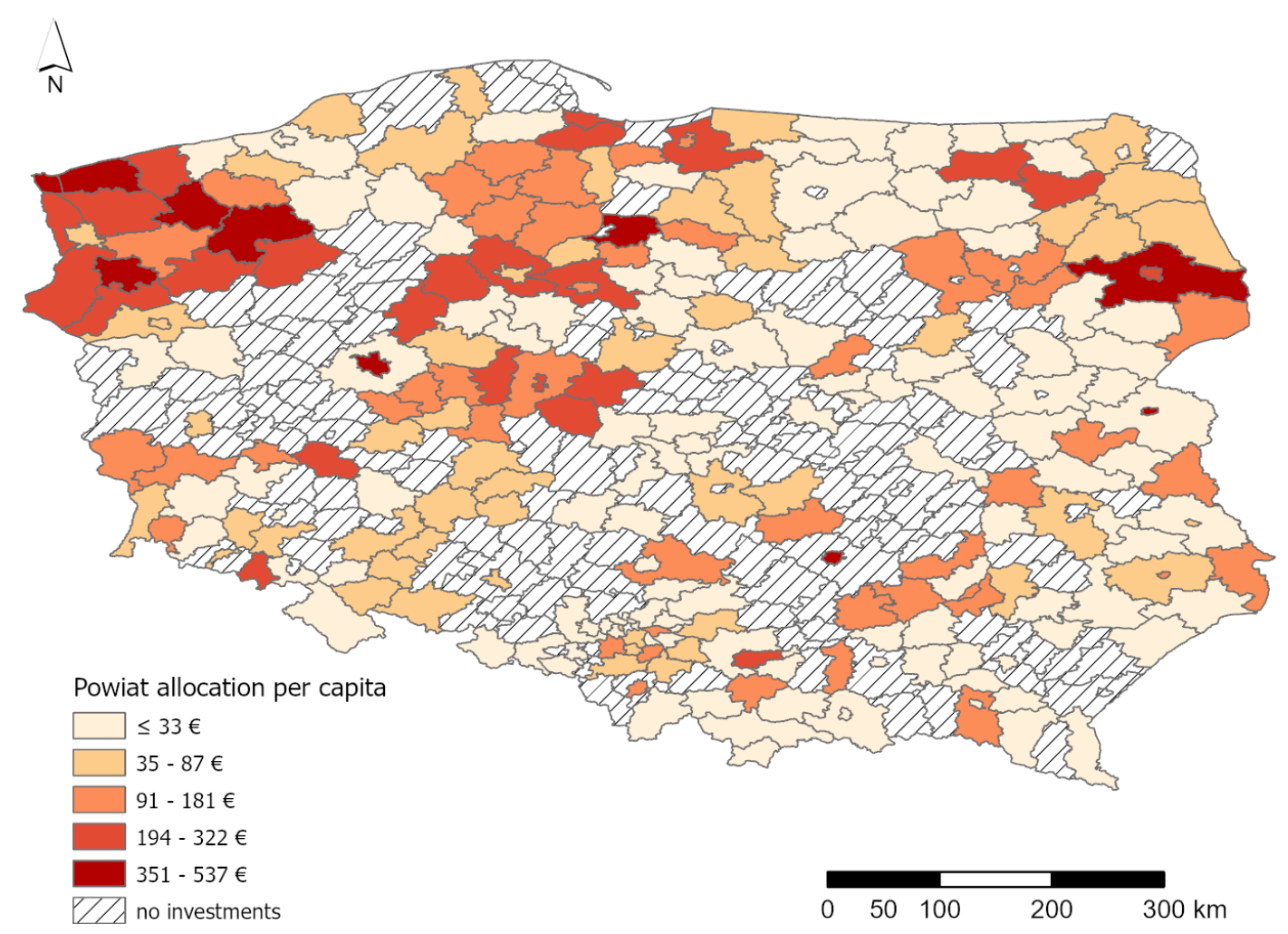

\subsubsection{Assistance to Poland in 2014-2020}

Poland's 2014-2020 period saw a new Partnership agreement that established operational programmes' structure and divided $€ 85,46$ bil. among them. The structure of operational programmes in which the waste management of solid municipal waste highlighted remained the same as in the previous programming period - a central Operational Programme Infrastructure and Environment and 16 regional operational programmes of the voivodeships. The Partnership agreement mentioned the reform of municipal waste management systems for which municipalities were now fully responsible. The biggest issue the documents noted was developing systems for the collection of sorted waste, which would then be ready for recycling. At the same time, the necessity to decrease the amount of municipal waste was emphasized as well. ${ }^{281}$

The Operational Programme Infrastructure and Environment repeated some points of the Partnership agreement. Furthermore, it highlighted the necessity to improve municipal waste collection regarding its sorting and its energetic use utilizing thermal disposal. It also emphasized the need to educate people to decrease the volume of produced waste and increase the share of sorted waste. ${ }^{282}$ The total allocation of the programme was $€ 27410$ mil., including the performance reserve. Within this allocation, the priority axis Protection of environment and climate change adaptation was funded by $€ 3508$ mil. from the cohesion policy resources. The

279 Ibid.

${ }^{280}$ GLÓWNY URZĄD GEODEZJI I KARTOGRAFII. Dane z państwowego rejestru granic i powierzchni jednostek podziałów terytorialnych kraju - PRG, 2021. Available on-line at http://www.gugik.gov.pl/pzgik/danebez-oplat/dane-z-panstwowego-rejestru-granic-i-powierzchni-jednostek-podzialow-terytorialnych-kraju-prg. ${ }^{281}$ MINISTERSTWO FUNDUSZY I POLITYKI REGIONALNEJ. Umowa Partnerstwa, 2020. Available on-line at https://www.funduszeeuropejskie.gov.pl/strony/o-funduszach/dokumenty/umowa-partnerstwa/.

282 MINISTERSTWO FUNDUSZY I POLITYKI REGIONALNEJ. Program Infrastruktura i Środowisko 20142020, 2020. Available on-line at https://www.pois.gov.pl/strony/o-programie/dokumenty/program-operacyjnyinfrastruktura-i-srodowisko-2014-2020/. 
priority axis, however, had a much broader scope than dealing with solid municipal waste. It also dealt with water management, wastewater management, environmental protection, and municipal greenery. As a result, the SMW interventions were assigned more than $€ 301$ mil.

As of July, $1^{\text {st }} 2020$, this priority axe saw 67 projects dealing with solid municipal waste. Again, these were more complex projects oriented on building new facilities across the territory of Poland in which the municipal waste would be collected and the improvement of existing facilities. These projects dealt with multiple types of interventions. In addition, however, more specialized projects began to emerge, dealing specifically with biodegradable waste or improvement to sorting by acquiring new technologies. These projects amounted to $€ 632,4$ mil. of total investments, $€ 263,5$ mil. was provided by the cohesion policy funding (calculated using exchange rate 4,297 PLN to $1 €)^{283}$

These activities were complemented by projects implemented within the regional operational programmes of 16 Polish voivodeships. As in the previous period, each of them had a priority axis aimed at environmental protection that dealt with solid municipal waste issues. However, their share on total programme allocations dropped significantly and ranged from $3 \%$ to $10 \%$ only. Furthermore, these priority axes were broadly determined and focused on other environmental issues as well.

Table 15: Regional Operational Programmes in Poland, 2014-2020 programming period

\begin{tabular}{|l|l|r|r|}
\hline Programme & Priority axis & $\begin{array}{l}\text { Allocation of } \\
\text { Programme } \\
\text { mil.) }\end{array}$ & $\begin{array}{l}\text { Allocation of } \\
\text { Priority axis }\end{array}$ \\
\hline $\begin{array}{l}\text { Operational Programme } \\
\text { 'Lower Silesia'284 }\end{array}$ & Environment and resources & 2252 & 176,5 \\
\hline $\begin{array}{l}\text { Operational Programme } \\
\text { 'Zachodniopomorskie'285 }\end{array}$ & $\begin{array}{l}\text { Environmental protection and } \\
\text { climate change adaptation }\end{array}$ & 1884 & 67,0 \\
\hline $\begin{array}{l}\text { Operational programme } \\
\text { 'Greater Poland'286 }\end{array}$ & Environment & 2450 & 172,0 \\
\hline $\begin{array}{l}\text { Operational Programme } \\
\text { 'Warminsko-Mazurskie'287 }\end{array}$ & $\begin{array}{l}\text { Environment and rational use of } \\
\text { resources }\end{array}$ & 1728 & 82,9 \\
\hline
\end{tabular}

${ }^{283}$ EUROPEAN CENTRAL BANK, ECB euro reference exchange rate: Polish zloty (PLN), 2020. Available online at

https://www.ecb.europa.eu/stats/policy_and_exchange_rates/euro_reference_exchange_rates/html/eurofxrefgraph-pln.en.html.

284 URZA_D MARSZALKOWSKI WOJEWÓDZTWA DOLNOŚLA_SKIEGO. Regionalny Program Operacyjny Województwa Dolnośląskiego 2014-2020, 2019. Available on-line at http:/ / rpo.dolnyslask.pl/regionalny-programoperacyjny-wojewodztwa-dolnoslaskiego-2014-2020/

${ }^{285}$ URZADD MARSZAŁKOWSKI WOJEWÓDZTWA ZACHODNIOPOMORSKIEGO. Regionalny Program Operacyjny Województwa Zachodniopomorskiego 2014-2020, 2020. Available on-line at https://rpo.wzp.pl/oprogramie/poznaj-program-regionalny-i-jego-zasady/regionalny-program-operacyjny-wojewodztwazachodniopomorskiego-2014-2020

${ }^{286}$ URZĄD MARSZAŁKOWSKI WOJEWÓDZTWA WIELKOPOLSKIEGO. Wielkopolski Regionalny Program Operacyjny na lata 2014-2020, 2020. Available on-line at https://wrpo.wielkopolskie.pl/dowiedz-siewiecej-o-programie/zapoznaj-sie-z-prawem-i-dokumentami/756

${ }^{287}$ URZAD MARSZAŁKOWSKI WOJEWÓDZTWA WARMIŃSKO-MAZURSKIEGO. Regionalny Program Operacyjny Województwa Warminsko-Mazurskiego na lata 2014-2020, 2020. Available on-line at https:// rpo.warmia.mazury.pl/plik/3/regionalny-program-operacyjny-wojewodztwa-warminsko-mazurskiego-nalata-2014-2020 


\begin{tabular}{|l|l|r|r|}
\hline $\begin{array}{l}\text { Operational Programme } \\
\text { 'Podlaskie'288 }\end{array}$ & $\begin{array}{l}\text { Environmental protection and } \\
\text { rational management of its } \\
\text { resources }\end{array}$ & 1213 & 43,2 \\
\hline $\begin{array}{l}\text { Operational Programme } \\
\text { 'Kujawsko-Pomorskie'289 }\end{array}$ & Environmentally friendly region & 1903 & 103,0 \\
\hline $\begin{array}{l}\text { Operational Programme } \\
\text { 'Mazovia'290 }\end{array}$ & Environmentally friendly economy & 2090 & 68,3 \\
\hline $\begin{array}{l}\text { Operational Programme } \\
\text { 'Oppolskie'291 }\end{array}$ & $\begin{array}{l}\text { Protection of the environment, } \\
\text { cultural and natural heritage }\end{array}$ & 905 & 88,3 \\
\hline $\begin{array}{l}\text { Operational Programme } \\
\text { 'Lubelskie'292 }\end{array}$ & $\begin{array}{l}\text { Environmental protection and } \\
\text { resource efficiency }\end{array}$ & 229 & 170,7 \\
\hline $\begin{array}{l}\text { Operational Programme } \\
\text { 'Silesia'293 }\end{array}$ & $\begin{array}{l}\text { Environmental protection and } \\
\text { resource efficiency }\end{array}$ & 3477 & 205,7 \\
\hline $\begin{array}{l}\text { Operational Programme } \\
\text { 'Świętokrzyskie'294 }\end{array}$ & Natural and cultural heritage & 1605 & 160,6 \\
\hline $\begin{array}{l}\text { Operational Programme } \\
\text { 'Lubuskie'295 }\end{array}$ & Environment and culture & 2114 & 189,2 \\
\hline $\begin{array}{l}\text { Operational Programme } \\
\text { 'Podkarpackie'296 }\end{array}$ & $\begin{array}{l}\text { Protection of the natural } \\
\text { environment and cultural heritage }\end{array}$ & 1865 & 120,9 \\
\hline $\begin{array}{l}\text { Operational Programme } \\
\text { 'Pomerania'297 }\end{array}$ & Environment & & \\
\hline
\end{tabular}

288 URZA_D MARSZAŁKOWSKI WOJEWÓDZTWA PODLASKIEGO. Regionalny Program Operacyjny Województwa Podlaskiego na lata 2014-2020, 2020. Available on-line at

https://rpo.wrotapodlasia.pl/pl/dowiedz_sie_wiecej_o_programie/zapoznaj_sie_z_prawem_i_dokument/regional ny-program-operacyjny-wo.html

289 MINISTERSTWO FUNDUSZY I POLITYKI REGIONALNEJ. Regionalny Program Województwa Kujawsko-Pomorskiego 2014-2020, 2020. Available on-line at https://www.funduszeeuropejskie.gov.pl/strony/ofunduszach/dokumenty/regionalny-program-operacyjny-wojewodztwa-kujawsko-pomorskiego-2014-2020/ ${ }^{290}$ MAZOWIECKA JEDNOSTKA WDRAŻANIA PROGRAMÓW UNIJNYCH. Regionalny Program Operacyjny Województwa Mazowieckiego 2014-2020, 2018. Available on-line at https://www.funduszedlamazowsza.eu/dokument/zapoznaj-sie-z-prawem-i-dokumentami/regionalny-programoperacyjny-wojewodztwa-mazowieckiego-2014-2020/

${ }^{291}$ MINISTERSTWO FUNDUSZY I POLITYKI REGIONALNEJ. Regionalny Program Województwa Opolskiego 2014-2020, 2020. Available on-line at https://www.funduszeeuropejskie.gov.pl/strony/ofunduszach/dokumenty/regionalny-program-wojewodztwa-opolskiego-2014-2020/

${ }^{292}$ URZADD MARSZAEKOWSKI WOJEWÓDZTWA LUBELSKIEGO W LUBLINIE. Regionalny Program Operacyjny Województwa Lubelskiego na lata 2014-2020, 2014. Available on-line at

https://rpo.lubelskie.pl/site/assets/files/1194/projekt_regionalnego_programu_operacyjnego_wojewodztwa_lubel skiego_2014_2020_wer_3.pdf

293 ZARZĄD WOJEWÓDZTWA ŚLĄSKIEGO. Regionalny Program Operacyjny Województwa Śląskiego na lata 2014-2020, 2020. Available on-line at

https://rpo.slaskie.pl/dokument/regionalny_program_operacyjny_wojewodztwa_slaskiego_na_lata_2014_2020_akt ualizacja_v5

${ }^{294}$ ZARZADD WOJEWÓDZTWA ŚWIẼTOKRZYSKIEGO. Regionalny Program Operacyjny Województwa

Świętokrzyskiego 2014-2020, 2020. Available on-line at http:/ /www.2014-2020.rpo-swietokrzyskie.pl/dowiedz-siewiecej-o-programie/zapoznaj-sie-z-prawem-i-dokumentami/dokumenty-regionalne/item/152-regionalny-programoperacyjny-wojewodztwa-swietokrzyskiego-na-lata-2014-2020

295 ZARZĄD WOJEWÓDZTWA LUBUSKIEGO. Regionalny Program Operacyjny - Lubuskie 2020, 2020.

Available on-line at https://rpo.lubuskie.pl/-/regionalny-program-operacyjny-lubuskie-2020

296 ZARZĄD WOJEWÓDZTWA PODKARPACKIEGO. Regionalny Program Operacyjny Województwa

Podkarpackiego na lata 2014-2020, 2020. Available on-line at

https://www.rpo.podkarpackie.pl/index.php/dokumenty-programowe/278-regionalny-program-operacyjnywojeodztwa-podkarpackiego-na-lata-2014-2020

297 ZARZA_D WOJEWÓDZTWA POMORSKIEGO. Regionalny Program Operacyjny Województwa

Pomorskiego na lata 2014-2020, 2018. Available on-line at https://www.rpo.pomorskie.eu/-/rpo-wp-2014-2020zmiana-05-07-2018 


\begin{tabular}{|l|l|r|r|}
\hline $\begin{array}{l}\text { Operational Programme } \\
\text { 'Lesser Poland'298 }\end{array}$ & Environmental protection & 2878 & 112,2 \\
\hline $\begin{array}{l}\text { Operational Programme } \\
\text { 'Lódzkie'299 }\end{array}$ & Environmental protection & 2256 & 82,7 \\
\hline
\end{tabular}

Projects funded through the regional operational programmes aimed to improve waste collection on the regional level by building waste collection points, modernising them, removing dangerous waste, and by landfill reclamation. There were 304 projects with a collective investment of $€ 269$ mil. out of which $€ 161,1$ mil. was provided by the cohesion policy funding. As the programming period 2014-2020 was not yet over at the time of writing, these numbers were likely to change. Nevertheless, the investments as a whole have not yet reached the previous period, although the cohesion policy contribution to co-funding was already at the same level. Compared with the previous period, the average size of projects decreased in 11 regional operational programmes. In four cases, the size decreased significantly (below $50 \%$ of 2007-2013 values).

Table 16: Investments into SWM related projects in Polish Regional Operational Programmes, 2014-2020 programming period300

\begin{tabular}{|c|c|c|c|c|}
\hline \multirow[t]{2}{*}{ Operational programme } & $\begin{array}{l}\text { Total } \\
\text { sum }\end{array}$ & $\begin{array}{l}\text { EU } \\
\text { contribution }\end{array}$ & \multirow{2}{*}{$\begin{array}{l}\text { Number of } \\
\text { projects }\end{array}$} & \multirow{2}{*}{$\begin{array}{c}\text { Average } \\
\text { project size in } \\
€ \text { thousands }\end{array}$} \\
\hline & \multicolumn{2}{|c|}{ In $€$ mil. } & & \\
\hline Operational Programme 'Lower Silesia' & 49,31 & 28,96 & 16 & 3082 \\
\hline Operational Programme 'Zachodniopomorskie' & 13,78 & 6,56 & 7 & 1969 \\
\hline Operational programme 'Greater Poland' & 7,83 & 4,98 & 24 & 326 \\
\hline $\begin{array}{l}\text { Operational Programme 'Warminsko- } \\
\text { Mazurskie' }\end{array}$ & 19,90 & 10,57 & 16 & 1244 \\
\hline Operational Programme 'Podlaskie' & 6,76 & 4,10 & 8 & 845 \\
\hline Operational Programme 'Kujawsko-Pomorskie' & 21,21 & 15,79 & 9 & 2357 \\
\hline Operational Programme 'Mazovia' & 9,61 & 4,88 & 28 & 343 \\
\hline Operational Programme 'Opolskie' & 12,42 & 9,70 & 38 & 327 \\
\hline Operational Programme 'Lubelskie' & 38,72 & 21,04 & 7 & 5532 \\
\hline Operational Programme 'Silesia' & 4,34 & 2,60 & 5 & 867 \\
\hline Operational Programme 'Świętokrzyskie' & 6,27 & 4,02 & 7 & 895 \\
\hline Operational Programme 'Lubuskie' & 4,59 & 2,51 & 5 & 919 \\
\hline Operational Programme 'Podkarpackie' & 14,32 & 8,91 & 42 & 341 \\
\hline Operational Programme 'Pomerania' & 32,99 & 18,77 & 26 & 1269 \\
\hline Operational Programme 'Lesser Poland' & 23,58 & 15,51 & 59 & 400 \\
\hline Operational Programme 'Łódzkie' & 3,37 & 2,20 & 7 & 481 \\
\hline
\end{tabular}

298 ZARZĄD WOJEWÓDZTWA MAŁOPOLSKIEGO. Regionalny Program Operacyjny Województwa Małopolskiego na lata 2014-2020, 2020. Available on-line at https://www.rpo.malopolska.pl/oprogramie/zapoznaj-sie-z-prawem-i-dokumentami/regionalny-program-operacyjny-2014-2020 299 ZARZĄD WOJEWÓDZTWA LÓDZKIEGO. Regionalny Program Operacyjny Województwa Lódzkiego na lata 2014-2020, 2020. Available on-line at https://rpo.lodzkie.pl/dowiedz-sie-wiecej-o-programie/zapoznaj-sie-zprawem-i-dokumentami/item/196-regionalny-program-operacyjny-wojewodztwa-lodzkiego-na-lata-2014-2020 300 MINISTERSTWO FUNDUSZY I POLITYKI REGIONALNEJ. Lista projektów realizowanych z Funduszy Europejskich w Polsce w latach 2014-2020, 2020. Available on-line at https://www.funduszeeuropejskie.gov.pl/strony/o-funduszach/projekty/lista-projektow/lista-projektowrealizowanych-z-funduszy-europejskich-w-polsce-w-latach-2014-2020/. 


\section{Best practice: Smaller projects in Poland 2014-2020}

Financed by Operational Programme 'Mazovia' project titled "Model Point for the Selective Collection of Communal Waste in Wola Suchożebrska" represents a smaller scale collection points (PSZOK) for waste as a part of wider regional waste management system. This particular facility collects multiple types of waste, and the employees are not only able to deconstruct some types of waste (i.e., electrical appliances) in order to get material recycling and further use but they can also repair some items which will then be given to new users. The facility is also able to provide educational services for children. The access is free to citizens as a part of serviced paid for by the fees for municipal waste. ${ }^{301}$

As in the previous programming period, the public institutions were again the primary beneficiaries across all operational programmes. More than three-quarters of total allocation was spent by public section institutions, almost half by municipalities. The average size of projects declined in the public sector, whereas it remained approximately the same in the private sector. Private for-profit companies also increased their share of the total allocation of the projects.

Table 17: Applicant types across all Polish regional operational programmes and the national operational programme, 2014-2020 programming period 302

\begin{tabular}{|c|c|c|c|c|c|}
\hline \multirow{2}{*}{ Applicant type } & Total sum & $\begin{array}{l}\text { EU } \\
\text { contribution }\end{array}$ & \multirow{2}{*}{$\begin{array}{l}\% \text { of total } \\
\text { allocation }\end{array}$} & \multirow{2}{*}{$\begin{array}{l}\text { Number of } \\
\text { projects }\end{array}$} & \multirow{2}{*}{$\begin{array}{l}\text { Average project } \\
\text { size in } € \\
\text { thousands }\end{array}$} \\
\hline & \multicolumn{2}{|c|}{ In $€$ mil. } & & & \\
\hline $\begin{array}{l}\text { Public sector institutions } \\
\text { (total) }\end{array}$ & 683,16 & 330,96 & $76,3 \%$ & 352 & 1941 \\
\hline - municipalities & 433,31 & 189,13 & $48,4 \%$ & 294 & 1474 \\
\hline Private profit companies & 212,03 & 89,88 & $23,7 \%$ & 19 & 11160 \\
\hline
\end{tabular}

The distribution of investments per capita across Polish LAU 1 units (powiats and cities with powiat status) in the 2014-2020 period was at first glance more even than in 2007-2013. Although, some $9 \%$ of the allocation are unaccounted for in the figure below, as they were invested on a larger administrative scale than the LAU 1 units, hinting at more centralized handling of the projects. While the investments in the supported LAU 1 units were more even, the share of supported units declined to approximately $47 \%$ compared to $66 \%$ in the previous period. The most considerable total support was awarded in connection with large cities where new incineration plants for solid municipal waste were built. The per capita support, while more even, still reflected these large infrastructural projects in major cities and selected powiats.

301 ZAKłAD UTYLIZACJI ODPADÓW W SIEDLCACH. Nowy PSZOK w regionie, 2020. Available on-line at https://zuo.siedlce.pl/aktualnosci/nowy-pszok-w-regionie ; MAZOWIECKA JEDNOSTKA WDRAŻANIA PROGRAMÓW UNIJNYCH. Inwestujemy w PSZOKI, 2019. Available on-line at https://www.funduszedlamazowsza.eu/aktualnosci/inwestujemy-w-pszoki-lets-inwest-in-selective-waste-points/. 302 MINISTERSTWO FUNDUSZY I POLITYKI REGIONALNEJ. Lista projektów realizowanych z Funduszy Europejskich w Polsce w latach 2014-2020, 2020. Available on-line at https://www.funduszeeuropejskie.gov.pl/strony/o-funduszach/projekty/lista-projektow/lista-projektowrealizowanych-z-funduszy-europejskich-w-polsce-w-latach-2014-2020/. 


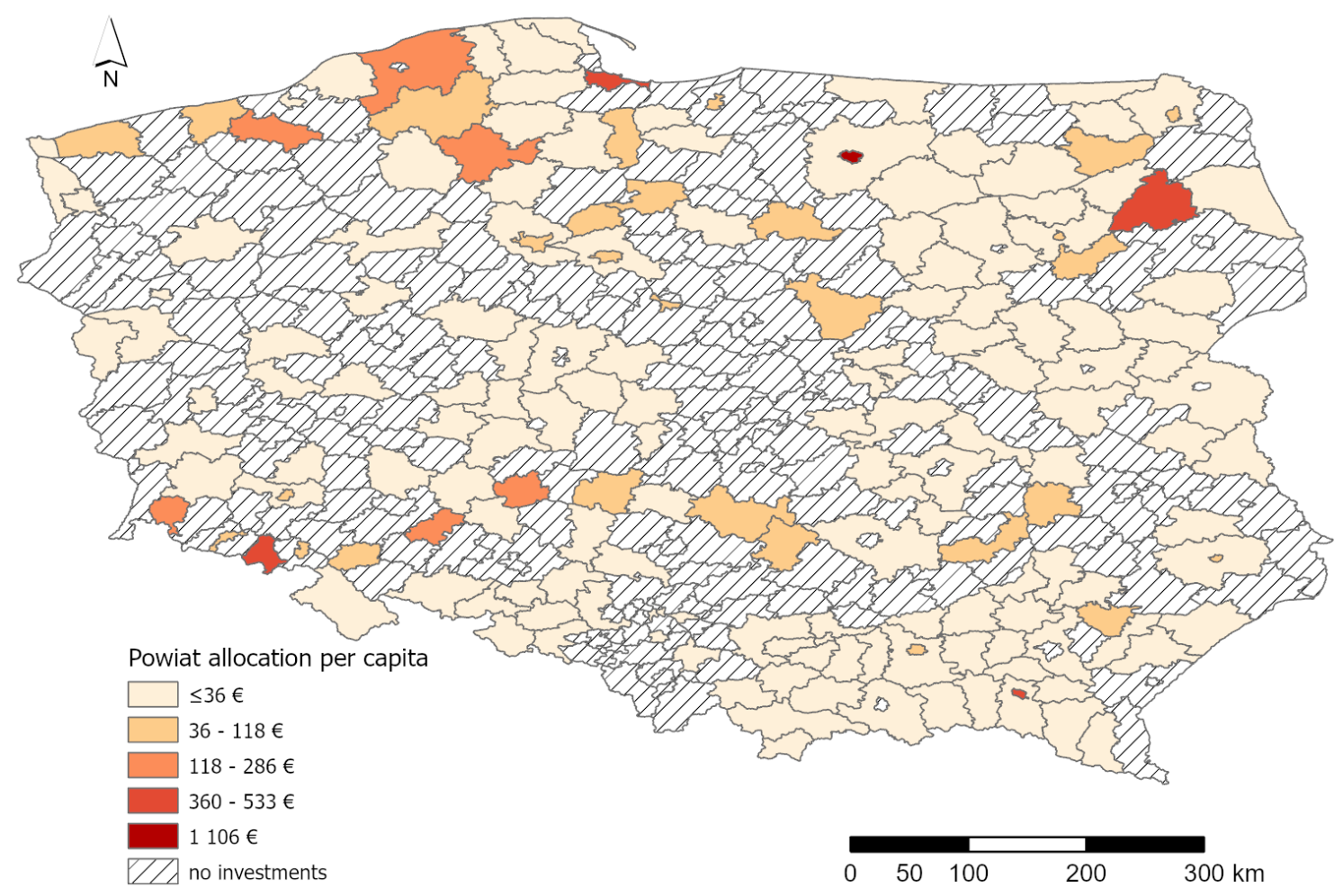

\subsection{Contribution to the Member States: Slovakia}

\subsubsection{Assistance to Slovakia in 2007-2013}

The Slovak National Strategic Reference Framework did, as in other member countries, set the strategy for Cohesion policy funds spending in the country during the 2007-2013 period. It also referenced the issues of waste management in general and municipal waste management in particular. Concerning waste management, the document emphasized the need to address increasing waste production by measures targeting a decrease in waste production, sorting, and further use of the produced waste. ${ }^{304}$ The production of solid municipal waste was, at the time, significantly lower than the EU average (by $42 \%$ ). Nevertheless, even for this area, the document suggested focusing on sorting, use, and final disposal, as increased production was anticipated. ${ }^{305}$ The prediction was correct, as the available data of Eurostat show. ${ }^{306}$

The measures concerning waste, including solid municipal waste, were concentrated in the operational programme Environment. This operational programme was allocated approximately $€ 1820$ mil. from the European Regional Development Fund and Cohesion Fund combined. ${ }^{307}$ It was divided into seven priority axes that covered various areas of environmental issues. The solid

303 Ibid.

304 GOVERNMENT OFFICE OF THE SLOVAK REPUBLIC. Národný strategický referenčný rámec SR 2007 -

2013, 2013. Available on-line at

http://www.nsrr.sk/download.php?FNAME=1386250293.upl\&ANAME=NSRR+07-13+april+2013+b.zip.

305 Ibid.

306 EUROSTAT. Municipal waste statistics, 2021. Available on-line at https://ec.europa.eu/eurostat/statisticsexplained/index.php/Municipal_waste_statistics\#Municipal_waste_generation.

${ }^{307}$ MINISTRY OF ENVIRONMENT OF THE SLOVAK REPUBLIC. Operačný program Životné prostredie, verzia 5.0, 2015. Available on-line at https://www.opzp.sk/wp-content/uploads/OPZP_verzia_5.0.pdf. 
municipal waste management, combined with general solid waste management, was covered by priority axis number four titled Waste management. Analysis of this operational programme too projected an increase in the amount of produced solid municipal waste and estimated that the most common final disposal method was landfilling with approximately $79 \%$ of such waste landfilled. ${ }^{308}$ Operational measures embedded in the fourth priority axis included support to increase in waste sorting, support to further use of the waste. It also focused on handling hazardous waste, rehabilitating old-polluted sites (especially brownfields), and landfill closing and reclamation. ${ }^{309}$

Priority axis four supported 308 projects in total amounting to $€ 474,4$ mil. The majority of these resources, $€ 415,9$ mil. were contributed from the cohesion policy. ${ }^{310}$ Not all of these projects were connected to the issues concerning solid municipal waste. Nevertheless, such projects prevailed as 245 such cases were identified, amounting to circa $€ 317$ mil. and $€ 281,3$ mil. of the cohesion policy support. Considering the smaller number of implemented projects, the thematic distribution on the level of individual projects was somewhat narrower than in the Czech Republic but broader than in Poland.

The highest percentage of allocation, almost one fourth, was spent on landfill reclamation, followed by investments into handling biodegradable waste. Projects dealing with the general improvement of waste sorting and building new facilities for waste processing were too strongly represented in the overall allocation. In general, the projects implemented in Slovakia focused firmly on broad topics of dealing with solid municipal waste, rather than specifically on various components of such waste. Except for biodegradable waste, a single focus on one element of SMW was less usual.

Table 18: Project types in Slovakia, programming period 2007 - 2013311

\begin{tabular}{|c|c|c|c|c|c|}
\hline \multirow[t]{2}{*}{ Project type } & Total sum & $\begin{array}{l}\text { EU } \\
\text { contribution }\end{array}$ & \multirow{2}{*}{$\begin{array}{l}\% \text { of } \\
\text { allocation* }\end{array}$} & \multirow{2}{*}{$\begin{array}{l}\text { Number of } \\
\text { projects }\end{array}$} & \multirow{2}{*}{$\begin{array}{l}\text { Average } \\
\text { project size in } \\
€ \text { thousands }\end{array}$} \\
\hline & \multicolumn{2}{|c|}{ In $€$ mil. } & & & \\
\hline $\begin{array}{l}\text { facilities: building new } \\
\text { facilities }\end{array}$ & 52,67 & 47,13 & $16,6 \%$ & 67 & 786 \\
\hline facilities: increasing capacity & 13,87 & 12,15 & $4,4 \%$ & 13 & 1067 \\
\hline landfill reclamation & 78,57 & 70,02 & $24,8 \%$ & 49 & 1603 \\
\hline new technologies & 25,46 & 22,13 & $8,0 \%$ & 13 & 1958 \\
\hline $\begin{array}{l}\text { waste handling: } \\
\text { biodegradable }\end{array}$ & 71,64 & 63,97 & $22,6 \%$ & 48 & 1493 \\
\hline waste handling: construction & 0,29 & 0,26 & $0,1 \%$ & 1 & 293 \\
\hline waste handling: electronics & 1,36 & 1,16 & $0,4 \%$ & 2 & 681 \\
\hline waste handling: plastics & 16,04 & 13,63 & $5,1 \%$ & 2 & 8020 \\
\hline $\begin{array}{l}\text { waste handling: sorting } \\
\text { improvement }\end{array}$ & 54,85 & 48,94 & $17,3 \%$ & 49 & 1119 \\
\hline waste handling: textile & 2,24 & 1,91 & $0,7 \%$ & 1 & 2242 \\
\hline
\end{tabular}

$*$ of 245 analysed projects

\footnotetext{
308 Ibid.

${ }^{309}$ Ibid.

310 MINISTRY OF ENVIRONMENT OF THE SLOVAK REPUBLIC. List of Beneficiaries - Operational

Programme Environment (31.12.2015), 2016. Available on-line at https:/ www.opzp.sk/wp-

content/uploads/Zoznam-prijimatelov_OP-ZP_31-12-2015.pdf.

311 Ibid.
} 
The public sector implemented most projects in Slovakia as it did in Poland and the Czech Republic. Such projects accounted for $86 \%$ of total allocation, and the vast majority was implemented by the municipalities, municipal associations or municipal service companies. The share of the private sector was significantly smaller, albeit with projects that were larger on average.

Table 19: Applicant types in Slovakia, programming period 2007 - 2013312

\begin{tabular}{|c|c|c|c|c|c|}
\hline \multirow[t]{2}{*}{ Applicant type } & Total sum & $\begin{array}{l}\text { EU } \\
\text { contribution }\end{array}$ & \multirow[t]{2}{*}{$\begin{array}{l}\% \text { of total } \\
\text { allocation }\end{array}$} & \multirow[t]{2}{*}{$\begin{array}{l}\text { Number of } \\
\text { projects }\end{array}$} & \multirow[t]{2}{*}{$\begin{array}{l}\text { Average project } \\
\text { size in } € \\
\text { thousands }\end{array}$} \\
\hline & \multicolumn{2}{|c|}{ In $€$ mil. } & & & \\
\hline $\begin{array}{l}\text { Public sector institutions } \\
\text { (total) }\end{array}$ & 272,23 & 243,24 & $85,9 \%$ & 229 & 1189 \\
\hline - $\quad$ municipalities & 271,69 & 242,78 & $85,7 \%$ & 220 & 1235 \\
\hline Private profit companies & 44,77 & 38,06 & $14,1 \%$ & 16 & 2798 \\
\hline
\end{tabular}

The projects implemented by municipalities were far less numerous than in the Czech Republic, more on par with the number of projects implemented in Poland. They were, however, more specialized than those in Poland. The majority of municipal efforts was aimed at landfill reclamation and handling of biodegradable waste. Significant efforts were also aimed at building new facilities for waste handling and improvement in sorting.

Table 20: Project types implemented by Slovak municipalities, programming period 2007 - 2013313

\begin{tabular}{|c|c|c|c|c|c|}
\hline \multirow[t]{2}{*}{ Project type } & Total sum & $\begin{array}{l}\text { EU } \\
\text { contribution }\end{array}$ & \multirow{2}{*}{$\begin{array}{l}\% \text { of total } \\
\text { allocation }\end{array}$} & \multirow{2}{*}{$\begin{array}{l}\text { Number of } \\
\text { projects }\end{array}$} & \multirow{2}{*}{$\begin{array}{l}\text { Average project } \\
\text { size in } € \\
\text { thousands }\end{array}$} \\
\hline & \multicolumn{2}{|c|}{ In $€$ mil. } & & & \\
\hline $\begin{array}{l}\text { facilities: building new } \\
\text { facilities }\end{array}$ & 52,67 & 47,13 & 67 & $19,4 \%$ & 786 \\
\hline facilities: increasing capacity & 8,15 & 7,29 & 9 & $3,0 \%$ & 905 \\
\hline landfill reclamation & 78,57 & 70,02 & 49 & $28,9 \%$ & 1603 \\
\hline new technologies & 10,91 & 9,77 & 10 & $4,0 \%$ & 1091 \\
\hline $\begin{array}{l}\text { waste handling: } \\
\text { biodegradable }\end{array}$ & 68,61 & 61,39 & 46 & $25,3 \%$ & 1492 \\
\hline waste handling: construction & 0,29 & 0,26 & 1 & $0,1 \%$ & 293 \\
\hline $\begin{array}{l}\text { waste handling: sorting } \\
\text { improvement }\end{array}$ & 52,48 & 46,93 & 38 & $19,3 \%$ & 1381 \\
\hline
\end{tabular}

Comparably, profit-oriented private companies more often focused on various projects dealing with specific types of waste and improving either their capacity or the technologies used in waste handling.

Table 21: Project types implemented by Slovak profit companies, programming period 2007 - 2013314

\begin{tabular}{|c|c|c|c|c|c|}
\hline \multirow{2}{*}{ Project type } & Total sum & $\begin{array}{l}\text { EU } \\
\text { contribution }\end{array}$ & \multirow{2}{*}{$\begin{array}{l}\% \text { of total } \\
\text { allocation }\end{array}$} & \multirow{2}{*}{$\begin{array}{l}\text { Number of } \\
\text { projects }\end{array}$} & \multirow{2}{*}{$\begin{array}{l}\text { Average project } \\
\text { size in } € \\
\text { thousands }\end{array}$} \\
\hline & \multicolumn{2}{|c|}{ In $€$ mil. } & & & \\
\hline
\end{tabular}

\footnotetext{
312 Ibid.

313 Ibid.

314 Ibid.
} 


\begin{tabular}{|l|r|r|r|r|r|}
\hline facilities: increasing capacity & 5,72 & 4,86 & 4 & $12,8 \%$ & 1430 \\
\hline new technologies & 14,54 & 12,36 & 3 & $32,5 \%$ & 4848 \\
\hline $\begin{array}{l}\text { waste handling: } \\
\text { biodegradable }\end{array}$ & 3,03 & 2,58 & 2 & $6,8 \%$ & 1515 \\
\hline $\begin{array}{l}\text { waste handling: electronics } \\
\text { waste handling: plastics }\end{array}$ & 1,36 & 1,16 & 2 & $3,0 \%$ & 681 \\
\hline $\begin{array}{l}\text { waste handling: sorting } \\
\text { improvement }\end{array}$ & 16,04 & 13,63 & 2 & $35,8 \%$ & 8020 \\
\hline $\begin{array}{l}\text { waste handling: textile } \\
\text { w }\end{array}$ & 1,83 & 1,56 & 2 & $4,1 \%$ & 916 \\
\hline
\end{tabular}

\section{Best practice: Increasing capacity of sorting facilities}

Prior to the implementation of the project titled "Separation facility on Sninská Street in Humenné", the city ty of Humenné had had a SMW handling system for sorted waste that covered approximately 35000 inhabitants and their households only partially. The city had increased the coverage of the sorting containers gradually. The project helped the municipality increase the coverage throughout its entire area and included constructing a sorting line and a separation hall to deal with sorted plastic, paper, and textile waste further. ${ }^{315}$

Spatial distribution of the investments among Slovak LAU 1, locally known as districts, shows that most of these administrative units were supported (approx. $78 \%$ ). The cluster of no support in the very western part of the country accounts for districts creating and surrounding the capital city. This part of the country was considered more developed, thus covered by a unique operational programme with little focus on SMW. The support of other LAU 1 units was relatively evenly distributed. Approximately 14,5\% of total allocation is not depicted, as the projects were not tied to a single identifiable LAU 1 units. Significant investments per capita were expended especially at landfill reclamation sites and in the vicinity of major cities.

315 MINISTRY OF ENVIRONMENT OF THE SLOVAK REPUBLIC. Information sheet of a succesfully implemented project, 2011. Available on-line at https://www.opzp.sk/wp-content/uploads/Info-listOPZP_4.1_PO_Humenné_Separačný-dvor-na-Sninskej-ulici.pdf. 


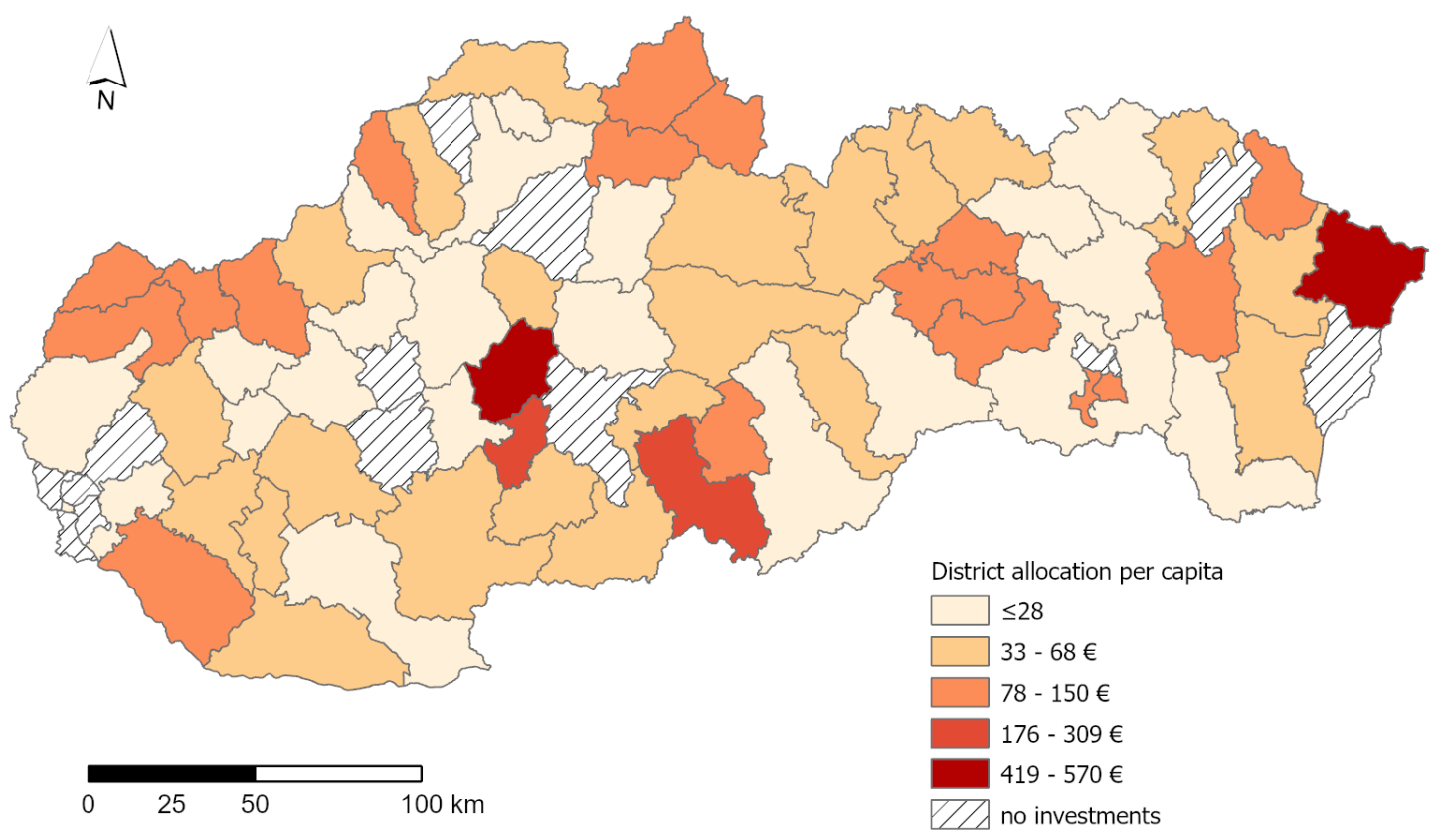

\subsubsection{Assistance to Slovakia in 2014-2020}

In the 2014-2020 programming period, the Slovak Partnership Agreement framed the cohesion policy investments in the country. The document was adopted in June 2014 and has been since updated to a second version. It replaced the National Strategic Reference Framework from the previous programming period and highlighted the issues of prevailing landfilling of waste in general and solid municipal waste in particular, and the objectives of sorting improvements in solid municipal waste produced, recycling and prevention of landfilling of biodegradable waste. ${ }^{317}$

The operational programme, which Partnership Agreement focused on environmental issues, including waste management, was titled Quality of Environment in the programming period 20142020. Waste management issues were tackled in its first of the five priority axes titled Sustainable use of natural resources through the development of environmental infrastructure. Altogether the operational programme was awarded an allocation of approximately $€ 3138$ mil. from Union resources, complemented by almost $€ 748$ mil. from national resources. The first priority axis Sustainable use of natural resources through development of environmental infrastructure alone planned investments of circa $€ 1442$ mil., financed by the EU and $€ 360$ mil. of national contribution $^{318}$. However, this large allocation was focused not only on solid waste management but also on water management, biodiversity management, urban revitalisation, brownfield reclamation, air pollution, or noise pollution issues.

As of June 2020, 415 SMW related projects accounted for $€ 222,2$ mil. contracted, out of which approximately $€ 181,6$ mil. was acquired from the EU cohesion policy funding. As with previous analysis, it is necessary to note that this was not the final state of the affairs as the programming period was not yet over at the time of project analysis for the purpose of this publication.

\footnotetext{
316 MINISTRY OF ENVIRONMENT OF THE SLOVAK REPUBLIC. List of Beneficiaries - Operational Programme Environment (31.12.2015), 2016. Available on-line at https://www.opzp.sk/wpcontent/uploads/Zoznam-prijimatelov_OP-ZP_31-12-2015.pdf.

317 SLOVAK REPUBLIC. Partnerská dohoda SR na roky 2014 - 2020, 2014. Available on-line at https://www.partnerskadohoda.gov.sk/zakladne-dokumenty/.

318 MINISTRY OF ENVIRONMENT OF THE SLOVAK REPUBLIC. Operational Programme Quality of Environment, 2018. Available on-line at https://www.partnerskadohoda.gov.sk/dokument-op-kzp-verzia-4/.
} 
The typological distribution of the projects is illustrated in the following table, keeping the schema already presented in the case of the Czech Republic. The comparably most significant part of the allocation was spent on the category of state projects. This was due to the presence of a project that dealt with financial instruments for waste management which was, in essence, a grant scheme within the operational programme. This part of the allocation was to be further distributed among final beneficiaries. Aside from this, the most supported type of projects in terms of total funding was handling biodegradable waste as in the previous period, followed by improvement to the network of waste handling facilities. Sorting of individual types of waste other than biodegradable was considerably less supported except for plastics. New activities which emerged in this period were concerned with education. Several projects dealt solely with the teaching of the general public the necessity of correct handling of SMW. Compared to the previous period, landfill reclamation is entirely missing as a category. That is not to say the efforts of kind stopped in the 2014-2020 programming period. Instead, they were shifted into the Ministry of Environment pioneered large projects that dealt with several sites at once, thus making it impossible to discern whether these were concerned with reclamation of landfilled SMW or other types of waste.

Table 22: Project types in Slovakia, programming period 2014-2020319

\begin{tabular}{|c|c|c|c|c|c|}
\hline Project type & Total sum & \begin{tabular}{|l}
$\begin{array}{l}\text { EU } \\
\text { contribution }\end{array}$ \\
$€$ mil.
\end{tabular} & $\begin{array}{l}\% \text { of } \\
\text { allocation* }\end{array}$ & $\begin{array}{l}\text { Number of } \\
\text { projects }\end{array}$ & $\begin{array}{l}\text { Average } \\
\text { project size in } \\
€ \text { thousands }\end{array}$ \\
\hline educational acitivities & 0,50 & 0,43 & $0,2 \%$ & 5 & 100 \\
\hline $\begin{array}{l}\text { facilities: building new } \\
\text { facilities }\end{array}$ & 33,71 & 27,39 & $15,2 \%$ & 63 & 535 \\
\hline facilities: increasing capacity & 3,50 & 2,97 & $1,6 \%$ & 10 & 350 \\
\hline new technologies & 3,89 & 3,03 & $1,8 \%$ & 11 & 354 \\
\hline state projects & 83,51 & 70,98 & $37,6 \%$ & 2 & $\begin{array}{r}41 \\
753 \\
\end{array}$ \\
\hline $\begin{array}{l}\text { waste handling: } \\
\text { biodegradable }\end{array}$ & 61,95 & 52,30 & $27,9 \%$ & 284 & 218 \\
\hline waste handling: electronics & 0,46 & 0,25 & $0,2 \%$ & 1 & 463 \\
\hline waste handling: plastics & 3,83 & 1,73 & $1,7 \%$ & 1 & 3833 \\
\hline waste handling: textile & 9,15 & 4,12 & $4,1 \%$ & 1 & 9149 \\
\hline $\begin{array}{l}\text { waste handling: sorting } \\
\text { improvement }\end{array}$ & 21,70 & 18,44 & $9,8 \%$ & 37 & 586 \\
\hline
\end{tabular}

$* \%$ of resources allocated to 415 analysed projects

\section{Best practice: Handling biodegradable waste from local households}

The project titled "Composting plant Handlová" addressed the issue of illegal dumping of biodegradable waste. Building a composting plant, including the equipment and containers, enabled people from 1800 family houses, yet more citizens from horticultural settlements, and suburban areas to process their biodegradable waste comfortably and find further use for compost

319 GOVERNMENT OFFICE OF THE SLOVAK REPUBLIC. List of Operations (30.7.2020), 2020. Available on-line at https://www.partnerskadohoda.gov.sk/data/att/10457.csv. 
As in the other countries and across programming periods, the public sector entities were prevalent among the beneficiaries of the EU support. The majority of the investments were implemented by Slovak municipalities, municipal associations, and municipal service organizations. The sizable category of others is represented by a single particular project described above as a grant scheme within the operational programme itself. Its presence significantly alters the share of allocation of the public sector. Nevertheless, as the final beneficiaries of this grant scheme are not analysed, the allocation is somewhat set aside in the description of applicant types.

Table 23: Applicant types in Slovakia, programming period 2014-2020321

\begin{tabular}{|l|r|r|r|l|r|}
\hline \multirow{2}{*}{ Applicant type } & Total sum & $\begin{array}{l}\text { EU } \\
\text { contribution }\end{array}$ & $\begin{array}{l}\text { \% of total } \\
\text { allocation }\end{array}$ & $\begin{array}{l}\text { Number of } \\
\text { projects }\end{array}$ & $\begin{array}{l}\text { Average project } \\
\text { size in } € \\
\text { thousands }\end{array}$ \\
\cline { 2 - 3 } $\begin{array}{l}\text { In } € \text { mil. } \\
\text { Public sector institutions } \\
\text { (total) }\end{array}$ & 132,25 & 112,36 & $59,5 \%$ & 402 & 329 \\
\hline$-\quad$ municipalities & 115,82 & 98,39 & $52,1 \%$ & 401 & 289 \\
\hline Private profit companies & 22,67 & 12,08 & $10,2 \%$ & 11 & 2061 \\
\hline Others & 67,28 & 57,19 & $30,3 \%$ & 2 & 33640 \\
\hline
\end{tabular}

Slovak municipalities focused their investments similarly as in the previous programming period 2007-2013. The largest shares of allocation were spent targeting handling biodegradable waste, building new facilities to deal with SMW and efforts were evident in the investments that aimed to improve sorting of SMW.

Table 24: Project types implemented by municipalities in Slovakia, programming period 2014-2020322

\begin{tabular}{|c|c|c|c|c|c|}
\hline \multirow[t]{2}{*}{ Project type } & Total sum & $\begin{array}{l}\text { EU } \\
\text { contribution }\end{array}$ & \multirow[t]{2}{*}{$\begin{array}{l}\% \text { of total } \\
\text { allocation }\end{array}$} & \multirow[t]{2}{*}{$\begin{array}{l}\text { Number of } \\
\text { projects }\end{array}$} & \multirow[t]{2}{*}{$\begin{array}{l}\text { Average project } \\
\text { size in } € \\
\text { thousands }\end{array}$} \\
\hline & \multicolumn{2}{|c|}{ In $€$ mil. } & & & \\
\hline educational activities & 0,16 & 0,14 & $0,1 \%$ & 3 & 54 \\
\hline $\begin{array}{l}\text { facilities: building new } \\
\text { facilities }\end{array}$ & 29,51 & 25,08 & $25,5 \%$ & 62 & 476 \\
\hline facilities: increasing capacity & 3,50 & 2,97 & $3,0 \%$ & 10 & 350 \\
\hline new technologies & 3,20 & 2,72 & $2,8 \%$ & 10 & 320 \\
\hline $\begin{array}{l}\text { waste handling: } \\
\text { biodegradable }\end{array}$ & 59,39 & 50,43 & $51,3 \%$ & 281 & 211 \\
\hline $\begin{array}{l}\text { waste handling: sorting } \\
\text { improvement }\end{array}$ & 20,07 & 17,06 & $17,3 \%$ & 35 & 573 \\
\hline
\end{tabular}

${ }^{320}$ EUROPEAN COMMISSION. Turning green waste into quality compost in Handlová, Slovakia, 2020. Available on-line at https://ec.europa.eu/regional_policy/en/projects/Slovakia/turning-green-waste-into-quality-compost-inhandlova-slovakia.

321 GOVERNMENT OFFICE OF THE SLOVAK REPUBLIC. List of Operations (30.7.2020), 2020. Available on-line at https://www.partnerskadohoda.gov.sk/data/att/10457.csv.

322 Ibid. 
The scope of activities of private companies was very diverse, albeit limited as to the number of projects.

Table 25: Project types implemented by private companies in Slovakia, programming period 2014-2020323

\begin{tabular}{|c|c|c|c|c|c|}
\hline \multirow[t]{2}{*}{ Project type } & Total sum & $\begin{array}{l}\text { EU } \\
\text { contribution }\end{array}$ & \multirow[t]{2}{*}{$\begin{array}{l}\% \text { of total } \\
\text { allocation }\end{array}$} & \multirow[t]{2}{*}{$\begin{array}{l}\text { Number of } \\
\text { projects }\end{array}$} & \multirow[t]{2}{*}{$\begin{array}{l}\text { Average project } \\
\text { size in } € \\
\text { thousands }\end{array}$} \\
\hline & \multicolumn{2}{|c|}{ In $€$ mil. } & & & \\
\hline educational activities & 0,13 & 0,11 & $0,6 \%$ & 1 & 131 \\
\hline $\begin{array}{l}\text { facilities: building new } \\
\text { facilities }\end{array}$ & 4,20 & 2,31 & $18,5 \%$ & 1 & 4200 \\
\hline new technologies & 0,70 & 0,31 & $3,1 \%$ & 1 & 697 \\
\hline $\begin{array}{l}\text { waste handling: } \\
\text { biodegradable }\end{array}$ & 2,57 & 1,87 & $11,3 \%$ & 3 & 855 \\
\hline waste handling: electronics & 0,46 & 0,25 & $2,0 \%$ & 1 & 463 \\
\hline waste handling: plastics & 3,83 & 1,73 & $16,9 \%$ & 1 & 3833 \\
\hline $\begin{array}{l}\text { waste handling: sorting } \\
\text { improvement }\end{array}$ & 1,63 & 1,39 & $7,2 \%$ & 2 & 815 \\
\hline waste handling: textile & 9,15 & 4,12 & $40,4 \%$ & 1 & 9149 \\
\hline
\end{tabular}

The spatial distribution of investments across Slovak LAU 1 units was even more widespread in the 2014-2020 programming period when circa $87 \%$ of districts were supported. Clusters of not supported districts are evident in the western part of the country around the capital city and in the south-eastern part around the second largest city of Košice. More than $37 \%$ of total allocation is not depicted owing in lesser part to projects implemented at larger administrative levels, but primarily due to the particular grant scheme's existence administered further to final beneficiaries. The most supported districts owe their pre-eminence to infrastructure-related projects, albeit not the landfill reclaiming as previously, instead projects aimed at SMW large scale operations, both public and private.

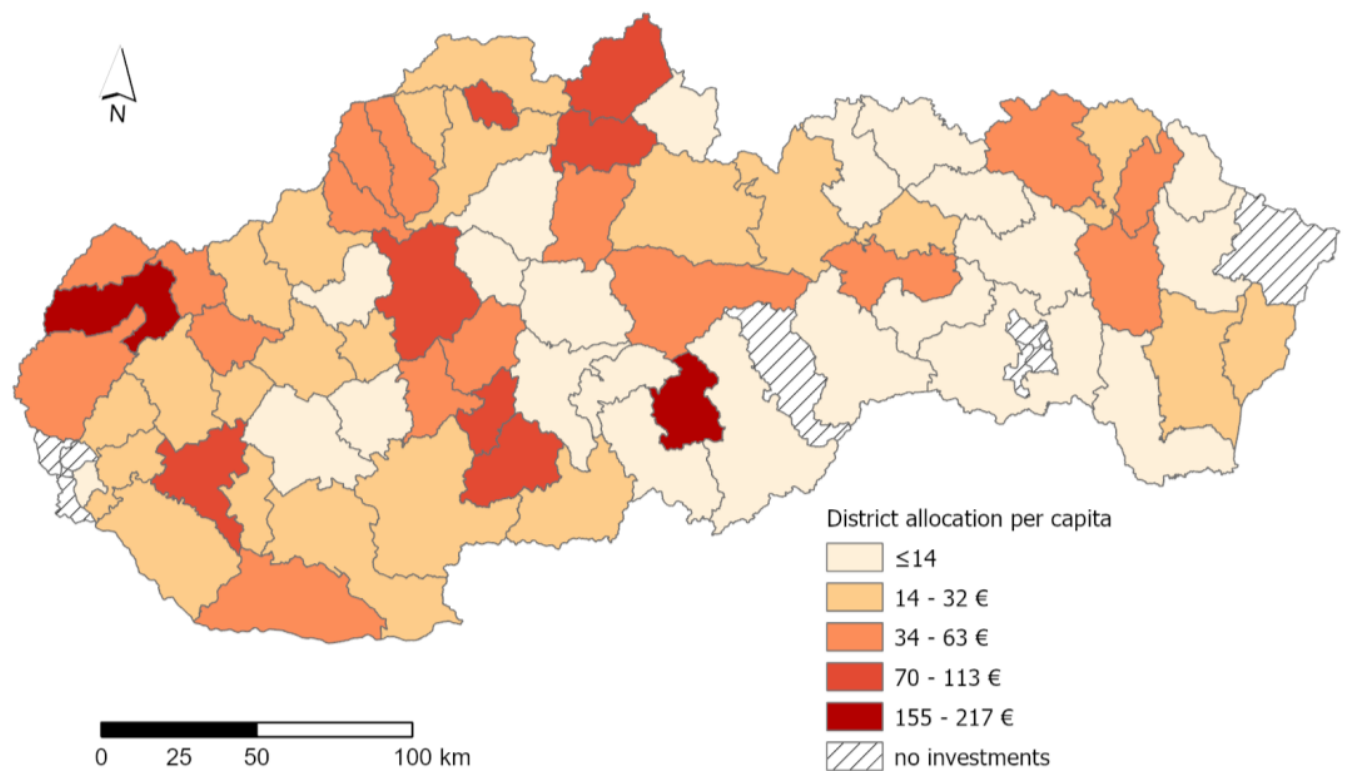

323 Ibid.

324 Ibid. 


\title{
4 Conclusion and lessons learned for Ukraine
}

\author{
Jiř̌ Zicha, Lenka Smékalová, Liudmyla Golovko
}

Since signing the Association Agreement with the European Union in 2014, ${ }^{325}$ Ukraine has continued to carry out the process of adaptation of its legislation in the field of waste management to European standards. According to the Agreement, Ukraine is not obliged to transpose and implement all EU waste acquis but only three Directives, namely the Directive on waste, the Directive on the landfill of waste and the Directive on the management of waste from extractive industries. ${ }^{326}$ However, even that is a challenging task while the waste management has always been and further remains a complicated agenda for all EU candidate countries and also the Member States.

First steps to adapt Ukrainian legislation to EU law have been made yet. On 8 November 2017, the Government approved the National Waste Management Strategy in Ukraine until 2030. The problem addressed by this Strategy is the need to resolve the critical situation that has developed with the formation, accumulation, storage, processing, and disposal of waste and is characterized by the further development of environmental threats. The problem of waste in Ukraine is particularly large-scale and significant both due to the dominance of resource-intensive multiwaste technologies in the national economy and due to the lack of adequate response to its challenges for a long time. Significant scales of resource use and energy and raw material specialization of the national economy together with the outdated technological base were determined and further determine the high rates of waste generation and accumulation. Such circumstances lead to a deepening environmental crisis and aggravation of the socioeconomic situation in society and necessitate reform and development considering domestic and international experience of the entire legal and economic system governing the use of natural resources in general and waste management in particular. The Strategy aims to introduce a systematic approach to waste management at the state and regional levels, reducing the volume of waste generation by increasing the volume of its recycling and reuse. ${ }^{327}$

In order to properly ensure the implementation of the National Strategy for Waste Management, the Cabinet of Ministers of Ukraine in 2019 approved the National Waste Management Plan until 2030. ${ }^{328}$ The document defines the tasks and practical measures necessary to improve solid waste management. The main tasks of the National Waste Management Plan are to determine specific socio-political, institutional, organizational, technical, regulatory, technological measures, responsible executors and deadlines for implementation of measures, sources and amounts of financial support, means of monitoring the implementation of measures and monitoring the results of reform in the field of waste management. The document, in particular, provides for the development of bills on waste management, disposal and incineration. Following the adoption of the law on waste management, the government must, in accordance with this plan, approve the National List of Waste, based on the European special procedure for waste classification, hazardous waste, and waste acceptance for different categories of landfills. In addition, the document provides for the development of the Waste Prevention Program and the introduction

\footnotetext{
${ }^{325}$ EUROPEAN UNION. Association Agreement between the European Union and its Member States, of the one part, and Ukraine, of the other part. OJ L 161, 29.5.2014, p. 3-2137.

${ }^{326}$ For more details, see ZICHA, J., GOLOVKO, L. Legislation of the European Union Related to Municipal Waste and its Reflection in the Association Agreement with Ukraine. Law - Human - Environment, vol. 10(4), 2019, p. $180-186$.

${ }^{327}$ Order of the Government of November 8, 2017 No. 820-p On Approval of the National Strategy for Waste Management in Ukraine until 2030. Available on-line at https://www.kmu.gov.ua/ua/npas/250431699.

328 Order of the Cabinet of Ministers of Ukraine of February 20, 2019 № 117-r On approval of the National Waste Management Plan until 2030. Available on-line at https://zakon.rada.gov.ua/laws/show/117-2019-0D1\%80
} 
of economic incentives for the introduction of environmentally friendly production technologies and expanding opportunities for waste processing. Among other things, the plan also provides for the establishment of the Industrial Waste Management Fund and the introduction of taxation of environmentally hazardous products. The plan provides for the development of a legal framework that will regulate the collection, processing and disposal of waste. These include approval of the national list of wastes based on the European one, the procedure for accepting waste at different categories of landfills and methods of environmental risk assessment of waste treatment facilities, the procedure for maintaining registers in the field of waste management, and the action plan for biodegradable waste reduction. Ministries are tasked with developing the Waste Prevention Program and regional administrations and local authorities should already be preparing drafts of regional waste management plans. The Ministry of Agrarian Policy, the Ministry of Economic Development, and the Ministry of Environment are responsible for drafting bills by 2020 on the introduction of economic instruments to stimulate the use of biomass from agricultural waste for the production of biofuels, electricity, and heat. ${ }^{329}$

Currently, the Ukrainian legal basis of waste management is set by the Law on environmental protection ${ }^{330}$ and the Law on waste. ${ }^{331}$ Further relevant norms include the Law on ensuring sanitary and epidemiological welfare of the population, ${ }^{332}$ Law on radioactive waste management, ${ }^{333}$ the Law on scrap metal ${ }^{334}$ and the Law on high-risk objects. ${ }^{335}$ These norms are further supplemented by secondary legislation, such as the Order of the Ministry of Housing and Communal Services of Ukraine on approval of the rules for the operation of landfills of household waste. ${ }^{336}$

However, the adaptation of legal rules is one step, crucial and necessary, but their proper and effective implementation is other no less important step. Previous chapters have shown that these two actions need to go hand in hand, while taking into consideration ongoing development in scientific knowledge, economy, trade, and other aspects of society that are also relevant for the management of waste. This agenda has its environmental background, but it also tackles numerous economic consequences, including utilization of European funds.

As described in the chapter on contribution to individual Member States, the analysis shows that the cohesion policy is a significant source of investment into the waste management systems of countries in question, including handling solid municipal waste. All analysed countries became EU members in 2004 and were awarded substantial allocations within the frame of cohesion policy since establishing themselves as members and even before, as the chapter on the Czech Republic shows. The approach to the distribution of these resources, however, differs across individual countries. The Czech Republic and Slovakia each chose to centralize the resources to

${ }^{329}$ RESPONSIBLE FUTURE. The Ukrainian government has approved a National Waste Management Plan until 2030. Available on-line at https://responsiblefuture.com.ua/ukrayinskij-uryad-zatverdiv-natsionalnij-planupravlinnya-vidhodami-do-2030-roku/.

${ }^{330}$ Law of Ukraine "On Environmental Protection" № 1264-XII of June 25, 1991 / / Bulletin of the Supreme Council of Ukraine, 1991, № 41, p.546

${ }^{331}$ Law of Ukraine "On Waste" 187/98-BP of March 5, 1998 // Bulletin of the Supreme Council of Ukraine, 1998, № 36-37, p.242

332 Law of Ukraine "On Ensuring Sanitary and Epidemiological Welfare of the Population" № 4005-XII of February 24, 1994 // Bulletin of the Supreme Council of Ukraine, 1994, № 27, p.218

333 Law of Ukraine "On Radioactive Waste Management" № 256/95-BP of June 30, 1995 // Bulletin of the Supreme Council of Ukraine, 1995, № 27, p.198

${ }^{334}$ Law of Ukraine "On Scrap Metal" № 619-XIV of September 15, 2016 // Bulletin of the Supreme Council of Ukraine, 1999, № 25, p.212

335 Law of Ukraine "On High Risk Objects" № 2245-III of April 26, 2014 // Bulletin of the Supreme Council of Ukraine, 2001, № 15, p.73

336 Order of the Ministry of Housing and Communal Services of Ukraine "On Approval of the Rules for the Operation of Landfills of Household Waste" № 1307/18602 of December 22, 2010. Available on-line at https://zakon.rada.gov.ua/laws/show/z1307-10\#Text. 
deal with environmental issues in a single operational programme. The Czech Republic first combined them with the issues of transport, as well, and separated them from the year 2007 on. On the other hand, Poland dealt with these issues within an extensive national Operational Programme Infrastructure and Environment, a combination similar to the early Czech approach, and complemented these activities with funding from regional operational programmes of individual voivodeships. While the approach to implementation differs, all countries used these investments to boost the infrastructure for handling solid municipal waste by building and improving systems of facilities for collection, sorting, and disposal of waste.

In addition, the countries invested in handling biodegradable waste to reduce the volume of landfilled waste and comply with EU legislation. The approach to individual projects is where the differences are most evident. The Czech Republic follows the path of implementing many smaller-scale projects, while both Slovak and Polish projects are larger financially and thematically more complex in Poland. The Polish approach reflects the reforms of handling the municipal waste, which transferred the responsibility for this type of waste since 1996, ${ }^{337}$ and the system as it was changed again in 2012. ${ }^{338}$ The Czech and Slovak municipalities dealt with building the waste collection systems as a part of their historical responsibilities. The Czech and Slovak Republics experienced somewhat lesser changes, as evidenced by regulations passed in the modern Czech Republic, ${ }^{339}$ with reforms focusing on payment systems ${ }^{340}$ and new types of waste that municipalities need to collect and dispose of.

For Ukraine, the cooperation with the European Union and convergence of legislature and practices concerning solid municipal waste presents a chance to establish a system and derive funding from EU resources in a similar way as the member states did, if at a smaller scale, to prepare the legislation, institutions and infrastructure. In addition, educational activities may complement the infrastructural projects. Some of these activities are already underway, including changes in Ukrainian legislation ${ }^{341}$ and pilot projects concerning waste management. ${ }^{342}$ Most importantly, the analysis of the three countries of different sizes and approaches indicates the importance of solid municipal waste related issues in the EU that transcends individual law systems, handling systems, and individual programming periods. It showcases the willingness on

\footnotetext{
337 ZEBEK, E., SZWEJKOWSKA, M., RACZKOWSKI, M. Legal and organisational solutions of municipal waste management in Poland in compliance with waste directive 2008/98/EC. Journal of Environmental Protection and Ecology, vol. 16(2), 2015, p. 652-658.

338 PRZYDATEK, G. Assessment of changes in the municipal waste accumulation in Poland. Environmental Science and Pollution Research, vol. 27(20), 2020, p. 25766-25773.; ALWAELI, M. An overview of municipal solid waste management in Poland. The current situation, problems and challenges. Environment Protection Engineering, vol. 41(4), 2015, p. 181-193.

${ }^{339}$ HADRABOVA, A., BILOPILSKA, O., SAUER, P. History of household waste management: Comparison of Ukraine and Czech Republic before 1989. Actual Problems of Economics, vol. 170(8), 2015, p. 24-27.;

HADRABOVA, A., BILOPILSKA, O., SAUER, P. History of household waste management: Comparison of Ukraine and the Czech republic after 1990. Actual Problems of Economics, vol. 171(9), 2015, p. 294-303.

340 ŠAUER, P., PAŘÍZKOVÁ, L., HADRABOVÁ, A. Charging systems for municipal solid waste: Experience from the Czech Republic. Waste Management, vol. 28(12), 2008, p. 2772-2777.

341 SHEVCHENKO, T., KOBLIANSKA, I., MARKOVA, O. Waste portable batteries and accumulators management in compliance with European union requirements in Ukraine: Present state and high priority activities. Journal of Environmental Management and Tourism, vol. 8(1), 2017, p. 232-246.; KIDALOV, S. et al. Legal regulation of waste management in ukraine on the way to european integration. European Journal of Sustainable Development, vol. 9(2), 2020, p. 422-430.

342 HUNGARY-SLOVAKIA-ROMANIA-UKRAINE ENPI CROSS-BORDER COOPERATION

PROGRAMME. Introduction of selective waste collection and recycling in the area of Beregovo, 2018. Available on-line at http://www.huskroua-cbc.net/en/project-database/142; HUNGARY-SLOVAKIA-ROMANIAUKRAINE ENI CBC PROGRAMME 2014-2020. Energy Recovery from Municipal Solid Waste by Thermal Conversion Technologies in Cross-border Region, 2020. Available on-line at https://huskrouacbc.eu/projects/ financed-projects-database/energy-recovery-from-municipal-solid-waste-by-thermal-conversiontechnologies-in-cross-border-region.
} 
the part of the EU and ability on the part of the individual member states and applicants to invest according to legal changes on the level of both the EU and individual member states with the common objective of improving the environmental indicators, involving new technologies, educating citizens, and making them involved in environmental protection and improvement of their living conditions. 


\section{List of sources}

Act No. 79/2015 Coll., on waste.

Act No. 125/1997 Coll., on waste.

Act No. 185/2001 Coll., on waste.

Act No. 223/2001 Coll., on waste.

Act No. 541/2020 Coll., on waste.

Act of 14 December 2012 on waste.

Act of 25 January 2013 amending the act on maintaining cleanliness and order in municipalities.

Act of 27 April 2001 on environmental protection.

ALWAELI, M. An overview of municipal solid waste management in Poland. The current situation, problems, and challenges. Environmental Protection Engineering, 2015, Vol. 41. № 4, p. 181-193.

ArcČR, STATE ADMINISTRATION OF LAND SURVEYING AND CADASTRE, CZECH STATISTICAL OFFICE. Digital Geographic Database ARC ČR 500, 2013. Available on-line at http://www.arcdata.cz/produkty/geograficka-data/arccr-500.

Association Agreement between the European Union and its Member States, of the one part, and Ukraine, of the other part. OJ L 161, 29.5.2014, p. 3-2137.

BACHTLER, J., BEGG, I. Cohesion policy after Brexit: The economic, social and institutional challenges. Journal of Social Policy, vol. 46(4), 2017, p. 745-763.

BAILEY, D., PROPRIS, L. De. The 1988 reform of the European Structural Funds: entitlement or empowerment? Journal of European Public Policy, vol. 9(3), 2002, p. 408-428.

BAILEY, I. New Environmental Policy Instruments in the European Union. Routledge, 2017, p. 234; DAVIES, P.G.G. European Union Environmental Law: An Introduction to Key Selected Issues [online] Routledge, 2017, p. 328.

Basel Convention on the Control of Transboundary Movements of Hazardous Wastes and Their Disposal (1999).

BIZNES.GOV.PL. Wpis do rejestru BDO (podmioty wprowadzające produkty, produkty w opakowaniach i gospodarujące odpadami). Available online at

https://www.biznes.gov.pl/pl/firma/obowiazki-przedsiebiorcy/chce-wypelniac-obowiazkisrodowiskowe/proc_170-wpis-do-rejestru-bdo-podmioty-wprowadzajace-produkty-produkty-wopakowaniach-i-gospodarujace-odpadami.

BIZNES.GOV.PL. Odpady - rejestracja, ewidencja i sprawozdawczość. Available online at https://www.biznes.gov.pl/pl/firma/obowiazki-przedsiebiorcy/chce-wypelniac-obowiazkisrodowiskowe/odpady-w-2020-r-rejestracja-ewidencja-i-sprawozdawczosc.

BOARD OF KUJAWSKO - POMORSKIE VOIVODESHIP. Regional Operational Programme of Kujawsko-Pomorskie Voivodeship for the years 2007-2013, 2011. Available online at http://2007-2013.mojregion.eu/tl_files/mojregion/dokumenty-rpo/Wazne dokumenty/Dokumenty programowe/Regional Operational Programme for K-P Voivodeshipv2-KE wersja ujednolicona grudzien 2011.pdf.

BOARD OF THE WIELKOPOLSKIE VOIVODSHIP. Wielkopolska Regional Operational Programme For 2007-2013, 2011. Available on-line at http://www.wrot.umww.pl/wpcontent/uploads/2014/08/WRPO_8_1_eng_version.pdf. 
BOURGUIGNON, D. Understanding waste streams: Treatment of specific waste. European Parliamentary Research Service, 2015.

BURGER, M., GUNDLACH, J. (eds.). Climate Change, Public Health, and the Law. Cambridge University Press, 2018, p. 266-267.

Case C-236/92, Comitato di Coordinamento per la Difesa della Cava and others v Regione Lombardia and others.

Case C-6/00, Abfall Service AG (ASA) v Bundesminister für Umwelt, Jugend und Familie.

Case C-292/12, Ragn-Sells AS v Sillamäe Linnavalitsus.

Cases C-206/88 and C-207/88, Vessaso and Zanetti.

CASTREE, N., HULME, M., PROCTOR, J. D. (eds.). Companion to Environmental Studies. Routledge, 2018.

Consolidated versions of the Treaty on European Union and the Treaty on the Functioning of the European Union, OJ C 326, p. 1-390.

Council Decision 93/98/EEC of 1 February 1993 on the conclusion, on behalf of the

Community, of the Convention on the control of transboundary movements of hazardous wastes and their disposal (Basel Convention). OJ L 39, p. 1-2.

Council Directive 75/439/EEC of 16 June 1975 on the disposal of waste oils, OJ L 194, p. 2325.

Council Directive 75/442/EEC of 15 July 1975 on waste. OJ L 194, p. 39-41.

Council Directive 86/278/EEC of 12 June 1986 on the protection of the environment, and in particular of the soil, when sewage sludge is used in agriculture. OJ L 181, p. 6-12.

Council Directive 91/156/EEC of 18 March 1991 amending Directive 75/442/EEC on waste, OJ L 78, p. 32-37.

Council Directive 1999/31/EC of 26 April 1999 on the landfill of waste. OJ L 182, p. 1-19.

Council Directive 2011/70/Euratom of 19 July 2011 establishing a Community framework for the responsible and safe management of spent fuel and radioactive waste. OJ L 199, p. 48-56.

COUNCIL OF THE EUROPEAN UNION. Food losses and food waste. Assessment of progress made in implementing the Council conclusions adopted on 28 June 2016. Note 11665/20, Brussels, 9. 11. 2020.

Council Regulation (Euratom) No 1493/93 of 8 June 1993 on shipments of radioactive substances between Member States. OJ L 148, p. 1-7. Council Directive 2006/117/Euratom of 20 November 2006 on the supervision and control of shipments of radioactive waste and spent fuel. OJ L 337, p. 21-32.

CZECH STATISTICAL OFFICE. Generation, Recovery and Disposal of Waste. Available online at https://www.czso.cz/csu/czso/produkce-vyuziti-a-odstraneni-odpadu-2018.

Decision No 1386/2013/EU of the European Parliament and of the Council of 20 November 2013 on a General Union Environment Action Programme to 2020 'Living well, within the limits of our planet', OJ L 354, p. 171-200.

Directive 2000/53/EC of the European Parliament and of the Council of 18 September 2000 on end-of life vehicles. OJ L 269, p. 34-43.

Directive 2000/59/EC of the European Parliament and of the Council of 27 November 2000 on port reception facilities for ship-generated waste and cargo residues. OJ L 332, p. 81-90. 
Directive 2000/76/EC of the European Parliament and of the Council of 4 December 2000 on the incineration of waste. OJ L 332, p. 91-111.

Directive 2005/64/EC of the European Parliament and of the Council of 26 October 2005 on the type-approval of motor vehicles with regard to their reusability, recyclability and recoverability and amending Council Directive 70/156/EEC. OJ L 310, p. 10-27.

Directive 2006/12/EC of the European Parliament and of the Council of 5 April 2006 on waste. OJ L 114, p. 9-21.

Directive 2006/21/EC of the European Parliament and of the Council of 15 March 2006 on the management of waste from extractive industries. OJ L 102, p. 15-34.

Directive 2006/66/EC of the European Parliament and of the Council of 6 September 2006 on batteries and accumulators and waste batteries and accumulators. OJ L 266, p. 1-14.

Directive 2008/98/EC of the European Parliament and of the Council of 19 November 2008 on waste and repealing certain Directives. OJ L 312, p. 3-30.

Directive 2010/75/EU of the European Parliament and of the Council of 24 November 2010 on industrial emissions (integrated pollution prevention and control). OJ L 334, p. 17-119.

Directive 2011/65/EU of the European Parliament and of the Council of 8 June 2011 on the restriction of the use of certain hazardous substances in electrical and electronic equipment. OJ L 174, p. 88-110.

Directive 2012/19/EU of the European Parliament and of the Council of 4 July 2012 on waste electrical and electronic equipment. OJ L 197, p. 38-71.

Directive (EU) 2015/720 of the European Parliament and of the Council of 29 April 2015 amending Directive 94/62/EC as regards reducing the consumption of lightweight plastic carrier bags. OJ L 115, p. 11-15.

DIRECTORATE-GENERAL FOR RESEARCH. The Environmental Situation in the Czech Republic, 2003. Available on-line at https://www.europarl.europa.eu/RegData/etudes/note/join/2003/323496/DG-4ENVI_NT(2003)323496_EN.pdf.

DRI, M., CANFORA, P., ANTONOPOULOS, I. S., GAUDILLAT, P., Best Environmental Management Practice for the Waste Management Sector, JRC Science for Policy Report.

Publications Office of the European Union, Luxembourg, 2018.

DUBOIS, M., SIMS, E., MOERMAN, T., WATSON, D., BAUER, B., BEL, J.-B., MEHLHART, G. Guidance for Separate Collection of Municipal Waste. Publications Office of the European Union, Luxembourg, 2020.

EIONET PORTAL. Waste and Materials in a Green Economy. Available online at https://www.eionet.europa.eu/etcs/etc-wmge.

EUR-LEX. Summaries of EU legislation. Available on-line at https://eurlex.europa.eu/browse/summaries.html.

EUROPEAN CENTRAL BANK, ECB euro reference exchange rate: Polish zloty (PLN), 2020. Available on-line at

https://www.ecb.europa.eu/stats/policy_and_exchange_rates/euro_reference_exchange_rates/ html/eurofxref-graph-pln.en.html.

EUROPEAN COMMISSION. Agenda 2000 - Commission Opinion on the Czech Republic's Application for Membership of the European Union, 1997. Available on-line at https://ec.europa.eu/commission/presscorner/detail/en/DOC_97_17. 
EUROPEAN COMMISSION. Annual Reports on Monitoring the Application of EU Law. Available on-line at https://ec.europa.eu/info/publications/annual-reports-monitoringapplication-eu-law_en.

EUROPEAN COMMISSION. Batteries and accumulators. Available online at https://ec.europa.eu/environment/topics/waste-and-recycling/batteries-and-accumulators_en.

EUROPEAN COMMISSION. Biodegradable waste. Available online at https://ec.europa.eu/environment/topics/waste-and-recycling/biodegradable-waste_en.

EUROPEAN COMMISSION. Changing the way we use plastics. Publications Office of the European Union, Luxembourg, 2018, p. 1.

EUROPEAN COMMISSION. Circular Economy. Available on-line at http:/ / ec.europa.eu/environment/circular-economy/index_en.htm.

EUROPEAN COMMISSION. Communication from the Commission to the European Parliament, the Council, the European Economic and Social Committee and the Committee of the Regions: A Farm to Fork Strategy for a fair, healthy and environmentally friendly food system. Brussels, 20.5.2020 COM(2018) 381 final.

EUROPEAN COMMISSION. Communication from the Commission to the European Parliament, the Council, the European Economic and Social Committee and the Committee of the Regions: Closing the loop - An EU action plan for the Circular Economy, Brussels, 2.12.2015 $\operatorname{COM}(2015) 614$ final.

EUROPEAN COMMISSION. Communication from the Commission to the European Parliament, the Council, the European Economic and Social Committee and the Committee of the Regions. The European Green Deal, COM(2019) 640 final.

EUROPEAN COMMISSION. Communication from the Commission to the European Parliament, the Council, the European Economic and Social Committee and the Committee of the Regions. A new Circular Economy Action Plan For a cleaner and more competitive Europe, $\operatorname{COM}(2020) 98$ final.

EUROPEAN COMMISSION. Environment Action Programme to 2020. Available on-line at https://ec.europa.eu/environment/action-programme/.

EUROPEAN COMMISSION. EU actions against food waste. Available online at https://ec.europa.eu/food/safety/food_waste/eu_actions_en.

EUROPEAN COMMISSION. Global Alliance on Circular Economy and Resource Efficiency (GACERE). Available on-line at https://ec.europa.eu/environment/international_issues/gacere.html.

EUROPEAN COMMISSION. Green Deal: Sustainable batteries for a circular and climate neutral economy. Available online at https://ec.europa.eu/commission/presscorner/detail/en/ip_20_2312.

EUROPEAN COMMISSION. Guidance on the interpretation of key provisions of Directive 2008/98/EC on waste. Brussels, 2012.

EUROPEAN COMMISSION. Landfill of waste. Available online at http://ec.europa.eu/environment/waste/landfill/index.htm.

EUROPEAN COMMISSION. Monitoring the Application of European Union Law, 2018 Annual Report.

EUROPEAN COMMISSION. Packaging waste. Available online at https://ec.europa.eu/environment/topics/waste-and-recycling/packaging-waste_en. 
EUROPEAN COMMISSION. PHARE Financing Memoranda \& Project Fiches, 2016. Available on-line at https:/ / ec.europa.eu/neighbourhood-enlargement/instruments/formerassistance/phare_en.

EUROPEAN COMMISSION. Preparing a Waste Management Plan: A Methodological Guidance Note. Brussels, 2012.

EUROPEAN COMMISSION. Report from the Commission to the European Parliament, the Council, the European Economic and Social Committee and the Committee of the Regions on the implementation of EU waste legislation, including the early warning report for Member States at risk of missing the 2020 preparation for re-use/recycling target on municipal waste. Brussels, 24.9.2018 COM(2018) 656 final.

EUROPEAN COMMISSION. Reporting on implementation of waste legislation. Available online at https://ec.europa.eu/environment/waste/reporting/index.htm.

EUROPEAN COMMISSION. Shipments of waste in the EU in the context of the coronavirus crisis. Available on-line at

https://ec.europa.eu/environment/waste/shipments/pdf/waste_shipment_and_COVID19.pdf.

EUROPEAN COMMISSION. Turning green waste into quality compost in Handlová, Slovakia, 2020. Available on-line at https://ec.europa.eu/regional_policy/en/projects/Slovakia/turninggreen-waste-into-quality-compost-in-handlova-slovakia.

EUROPEAN UNION. Association Agreement between the European Union and its Member States, of the one part, and Ukraine, of the other part. OJ L 161, 29.5.2014, p. 3-2137.

EUROPEAN UNION. Treaty of Accession of the Czech Republic, Estonia, Cyprus, Latvia, Lithuania, Hungary, Malta, Poland, Slovenia and Slovakia, 2003. Available on-line at https://eurlex.europa.eu/legal-content/EN/TXT/?uri=CELEX:12003T/TXT.

EUROPEAN COMMISSION. Waste Framework Directive: Inspections and enforcement. Available on-line at https://ec.europa.eu/environment/waste/framework/inspections.htm.

EUROPEAN COMMISSION. Waste from Electrical and Electronic Equipment (WEEE). Available online at https://ec.europa.eu/environment/topics/waste-and-recycling/wasteelectrical-and-electronic-equipment-weee_en.

EUROPEAN COMMISSION. Waste management in the context of the coronavirus crisis. Available on-line at https:/ / ec.europa.eu/info/files/waste-management-context-coronaviruscrisis_en.

EUROPEAN COMMISSION. Waste Management Planning. Available online at https://ec.europa.eu/environment/waste/plans/index.htm.

EUROPEAN COMMISSION. Waste Prevention. Available online at https://ec.europa.eu/environment/waste/prevention/index.htm.

EUROPEAN ENVIRONMENTAL AGENCY. About us. Available online at https://www.eea.europa.eu/about-us.

EUROPEAN ENVIRONMENTAL AGENCY. Resource efficiency and waste. Available online at https://www.eea.europa.eu/themes/waste.

European Parliament and Council Directive 94/62/EC of 20 December 1994 on packaging and packaging waste. OJ L 365, p. 10-23.

EUROSTAT. Glossary: Municipal waste. Available on-line at https://ec.europa.eu/eurostat/statistics-explained/index.php?title=Glossary:Municipal_waste. 
EUROSTAT. Municipal waste statistics. Available on-line at https://ec.europa.eu/eurostat/statistics-explained/index.php/Municipal_waste_statistics.

EUROSTAT. Waste - Overview. Available on-line at https://ec.europa.eu/eurostat/web/waste.

EUROSTAT. Waste statistics - electrical and electronic equipment. Available online at https://ec.europa.eu/eurostat/statistics-explained/index.php?title=Waste_statistics__electrical_and_electronic_equipment.

GLÓWNY URZĄD GEODEZJI I KARTOGRAFII. Dane z państwowego rejestru granic i powierzchni jednostek podziałów terytorialnych kraju - PRG, 2021. Available on-line at http://www.gugik.gov.pl/pzgik/dane-bez-oplat/dane-z-panstwowego-rejestru-granic-ipowierzchni-jednostek-podzialow-terytorialnych-kraju-prg

GOVERNMENT OFFICE OF THE SLOVAK REPUBLIC. List of Operations (30.7.2020), 2020. Available on-line at https://www.partnerskadohoda.gov.sk/data/att/10457.csv

GOVERNMENT OFFICE OF THE SLOVAK REPUBLIC. Národný strategický referenčný rámec SR 2007-2013, 2013. Available on-line at

http://www.nsrr.sk/download.php?FNAME =1386250293.upl\&ANAME=NSRR+0713+april+2013+b.zip

HADRABOVA, A., BILOPILSKA, O., SAUER, P. History of household waste management: Comparison of Ukraine and Czech Republic before 1989. Actual Problems of Economics, vol. 170(8), 2015, p. 24-27.; HADRABOVA, A., BILOPILSKA, O., SAUER, P. History of household waste management: Comparison of Ukraine and the Czech Republic after 1990. Actual Problems of Economics, vol. 171(9), 2015, p. 294-303.

HORSÁK, Z., HŘEBÍČEK, J. Biodegradable waste management in the Czech Republic. A proposal for improvement. Polish Journal of Environmental Studies, vol. 23(6), 2014, p. 20192025.

HOŠŤÁLKOVÁ MUNICIPALITY. Zahájení akce Rekultivace skládky TKO Fučínov, 2008. Available on-line at http://www.hostalkova.cz/e_download.php?file=data/uredni_deska/obsah366_1.pdf\&original $=$ TiskZpr_Fuc.pdf; MINISTRY OF REGIONAL DEVELOPMENT OF THE CZECH REPUBLIC. Rekultivace skládky TKO Fučínov, 2020. Available on-line at https://www.dotaceeu.cz/cs/statistiky-a-analyzy/mapa-projektu/projekty-pred-rokem-2014/2op-zivotni-prostredi/2-4-zkvalitneni-nakladani-s-odpady-a-odstranovani/rekultivace-skladkytko-fucinov.

HUNGARY-SLOVAKIA-ROMANIA-UKRAINE ENPI CROSS-BORDER COOPERATION PROGRAMME. Introduction of selective waste collection and recycling in the area of Beregovo, 2018. Available on-line at http://www.huskroua-cbc.net/en/projectdatabase/142; HUNGARY-SLOVAKIA-ROMANIA-UKRAINE ENI CBC PROGRAMME 2014-2020. Energy Recovery from Municipal Solid Waste by Thermal Conversion Technologies in Cross-border Region, 2020. Available on-line at https://huskroua-cbc.eu/projects/financedprojects-database/energy-recovery-from-municipal-solid-waste-by-thermal-conversiontechnologies-in-cross-border-region.

JANS, J. H., VEDDER, H. H. B. European Environmental Law: After Lisbon (Fourth Edition). Europa Law Publishing, 2012.

KACZMAREK, Z. Nowelizacja ustawy o utrzymaniu czystości i porządku w gminach - wejście w życie nowelizowanych przepisów. Available online at https://sozosfera.pl/odpady/nowelizacja-ustawy-o-utrzymaniu-czystosci-2/. 
KAH, S. et al. Strategic Coherence of Cohesion Policy: Comparison of the 2007-13 and 2014-20 Programming Periods, 2016. Available on-line at

https://pureportal.strath.ac.uk/en/publications/strategic-coherence-of-cohesion-policycomparison-of-the-2007-13-.

KINGSTON, S., HEYVAERT, V., ČAVOŠKI, A. European Environmental Law. Cambridge University Press, 2017.

KLING, M. et al. WEEE Compliance Promotion Exercise: Final report. Munich, 2017.

KOMPOSTÁRNA NÁKLO. Available online at http://www.tsnaklo.cz/kompostarna.

KUBICKA-ZACH, K., CYRANKIEWICZ-GORTYNSKI, M. Za rok 5-pojemnikowa segregacja śmieci wkroczy do wszystkich gmin. Available online at

https://www.prawo.pl/samorzad/segregacja-smieci-od-2019-roku,347745.html.

KUDRNA, Z. Long-term deformations of municipal landfill bodies and their effects on functional safety of superficial sealing. Acta Geodynamica et Geomaterialia, vol. 6(4), 2009, p. 465-473.

LANGLET, D., MAHMOUDI, S. EU Environmental Law and Policy. Oxford University Press. 2016, p. 285.

Law of Ukraine "On Environmental Protection" № 1264-XII of June 25, 1991 / / Bulletin of the Supreme Council of Ukraine, 1991, № 41, p.546

Law of Ukraine "On Waste" 187/98-BP of March 5, 1998 // Bulletin of the Supreme Council of Ukraine, 1998, № 36-37, p.242

Law of Ukraine "On Ensuring Sanitary and Epidemiological Welfare of the Population" № 4005-XII of February 24, 1994 // Bulletin of the Supreme Council of Ukraine, 1994, № 27, p.218.

Law of Ukraine "On Radioactive Waste Management" № 256/95-BP of June 30, 1995 //

Bulletin of the Supreme Council of Ukraine, 1995, № 27, p.198.

Law of Ukraine "On Scrap Metal" № 619-XIV of September 15, 2016 // Bulletin of the Supreme Council of Ukraine, 1999, № 25, p.212.

Law of Ukraine "On High Risk Objects" № 2245-III of April 26, 2014 / / Bulletin of the Supreme Council of Ukraine, 2001, № 15, p.73.

MAREK, D., BAUN, M. The EU as a regional actor: The case of the Czech Republic. Journal of Common Market Studies, vol. 40(5), 2002, p. 895-919.

MAZOWIECKA JEDNOSTKA WDRAŻANIA PROGRAMÓW UNIJNYCH. Regionalny Program Operacyjny Województwa Mazowieckiego 2014-2020, 2018. Available on-line at https://www.funduszedlamazowsza.eu/dokument/zapoznaj-sie-z-prawem-idokumentami/regionalny-program-operacyjny-wojewodztwa-mazowieckiego-2014-2020/

MINISTERSTWO FUNDUSZY I POLITYKI REGIONALNEJ. Lista beneficjentów Funduszy Europejskich 2007-2013 - stan na 31 grudnia 2018 r, 2019. Available on-line at https://www.funduszeeuropejskie.2007-

2013.gov.pl/NaborWnioskow/listabeneficjentow/Strony/Lista_beneficjentow_FE_31122018.as px

MINISTERSTWO FUNDUSZY I POLITYKI REGIONALNEJ. Lista projektów realizowanych z Funduszy Europejskich w Polsce w latach 2014-2020, 2020. Available on-line at https://www.funduszeeuropejskie.gov.pl/strony/o-funduszach/projekty/lista-projektow/listaprojektow-realizowanych-z-funduszy-europejskich-w-polsce-w-latach-2014-2020/ 
MINISTERSTWO FUNDUSZY I POLITYKI REGIONALNEJ. Program Infrastruktura i Środowisko 2014-2020, 2020. Available on-line at https:/ /www.pois.gov.pl/strony/oprogramie/dokumenty/program-operacyjny-infrastruktura-i-srodowisko-2014-2020/

MINISTERSTWO FUNDUSZY I POLITYKI REGIONALNEJ. Regionalny Program Województwa Kujawsko-Pomorskiego 2014-2020, 2020. Available on-line at https://www.funduszeeuropejskie.gov.pl/strony/o-funduszach/dokumenty/regionalnyprogram-operacyjny-wojewodztwa-kujawsko-pomorskiego-2014-2020/

MINISTERSTWO FUNDUSZY I POLITYKI REGIONALNEJ. Regionalny Program Województwa Lódzkiego, 2012. Available on-line at https://www.funduszeeuropejskie.20072013.gov.pl/rpo/strony/rpo_lodzkie.aspx

MINISTERSTWO FUNDUSZY I POLITYKI REGIONALNEJ. Regionalny Program Województwa Opolskiego 2014-2020, 2020. Available on-line at https://www.funduszeeuropejskie.gov.pl/strony/o-funduszach/dokumenty/regionalnyprogram-wojewodztwa-opolskiego-2014-2020/

MINISTERSTWO FUNDUSZY I POLITYKI REGIONALNEJ. Umowa Partnerstwa, 2020. Available on-line at https://www.funduszeeuropejskie.gov.pl/strony/ofunduszach/dokumenty/umowa-partnerstwa/

MINISTERSTWO ROZWOJU, PRACY I TECHNOLOGII. Rada Ministrów przyjęła projekt Mapy drogowej GOZ. Available online at https://www.gov.pl/web/rozwoj-pracatechnologia/rada-ministrow-przyjela-projekt-mapy-drogowej-goz.

MINISTRY OF ENVIRONMENT OF THE CZECH REPUBLIC. Programový dokument OPŽP pro období 2007-2013, verze 6, 2015. Available on-line at https:/ /archiv.opzp20072013.cz/soubor-ke-stazeni/57/17179-pd_opzp_verze_6_schvaleno_ek_27_10_2015.pdf.

MINISTRY OF ENVIRONMENT OF THE SLOVAK REPUBLIC. Information sheet of a succesfully implemented project, 2011. Available on-line at https://www.opzp.sk/wpcontent/uploads/Info-list-OPZP_4.1_PO_Humenné_Separačný-dvor-na-Sninskej-ulici.pdf MINISTRY OF ENVIRONMENT OF THE SLOVAK REPUBLIC. List of Beneficiaries Operational Programme Environment (31.12.2015), 2016. Available on-line at https://www.opzp.sk/wp-content/uploads/Zoznam-prijimatelov_OP-ZP_31-12-2015.pdf

MINISTRY OF ENVIRONMENT OF THE SLOVAK REPUBLIC. Operačný program Životné prostredie, verzia 5.0, 2015. Available on-line at https://www.opzp.sk/wpcontent/uploads/OPZP_verzia_5.0.pdf

MINISTRY OF ENVIRONMENT OF THE SLOVAK REPUBLIC. Operational Programme Quality of Environment, 2018. Available on-line at https://www.partnerskadohoda.gov.sk/dokument-op-kzp-verzia-4/.

MINISTRY OF REGIONAL DEVELOPMENT OF POLAND. Program operacyjny Infrastruktura i środowisko 2007-2013, wersja 5, 2016. Available on-line at https://www.pois.2007-

2013.gov.pl/Dokumenty/Documents/POIS_2007_2013_wersja_5_0.pdf

MINISTRY OF REGIONAL DEVELOPMENT OF POLAND. European Funds See changes in progress, 2012. Available on-line at https://www.pois.2007-

2013.gov.pl/dzialaniapromocyjne/Documents/Folder_ENG_29112012.pdf

MINISTRY OF REGIONAL DEVELOPMENT OF POLAND. Poland National Strategic

Reference Framework 2007-2013, 2007. Available on-line at www.mrr.gov.pl 
MINISTRY OF REGIONAL DEVELOPMENT OF THE CZECH REPUBLIC. List of Beneficiaries 02/2017, 2017. Available on-line at https://www.dotaceeu.cz/Dotace/media/SF/Informace o čerpání/Seznamy př́jemců (List of Beneficiaries)/2007-2013/Prehled-prijemcu_v2.xlsx

MINISTRY OF REGIONAL DEVELOPMENT OF THE CZECH REPUBLIC. List of Operations 07/2020, 2020. Available on-line at https:/ /www.dotaceeu.cz/getmedia/416fbafdbb47-4a56-907c-0033c64226c6/Seznam-operaci-(List-of-operations)-07_2020.xls.aspx?ext=.xls

MINISTRY OF REGIONAL DEVELOPMENT OF THE CZECH REPUBLIC. National Strategic Reference Framework of the Czech Republic 2007-2013, 2007. Available on-line at https://dotaceeu.cz/getmedia/316d70b9-76e1-4152-866d-1671ae735211/NSRR-AJ.pdf.aspx.

MINISTRY OF REGIONAL DEVELOPMENT OF THE CZECH REPUBLIC. Poř́zení biopopelnic pro Technické služby města Úvaly, 2020. Available on-line at https://www.dotaceeu.cz/cs/statistiky-a-analyzy/mapa-projektu/projekty/05-operacniprogram-zivotni-prostredi/05-3-odpady-a-materialove-toky,-ekologicke-zateze/porizenibiopopelnic-pro-technicke-sluzby-mesta-uv

MINISTRY OF REGIONAL DEVELOPMENT OF THE CZECH REPUBLIC. Pořizení štěpkovače a kontejnerů na Bioodpad pro město Vlašim?, 2020. Available on-line at https://www.dotaceeu.cz/cs/statistiky-a-analyzy/mapa-projektu/projekty/05-operacniprogram-zivotni-prostredi/05-3-odpady-a-materialove-toky,-ekologicke-zateze/porizenistepkovace-a-kontejneru-na-bioodpad-pro-m

MINISTRY OF REGIONAL DEVELOPMENT OF THE CZECH REPUBLIC. Předcházení vzniku biologicky rozložitelných odpadů v území obce Červená Voda, 2020. Available on-line at https://www.dotaceeu.cz/cs/statistiky-a-analyzy/mapa-projektu/projekty/05-operacniprogram-zivotni-prostredi/05-3-odpady-a-materialove-toky,-ekologicke-zateze/predchazenivzniku-biologicky-rozlozitelnych-(20).

MINISTRY OF REGIONAL DEVELOPMENT OF THE CZECH REPUBLIC. Výsledky čerpání; Programming period 2004-2006, 2021. Available on-line at

https://www.dotaceeu.cz/cs/evropske-fondy-v-cr/programove-obdobi-2004-2006-

(1)/vysledky-cerpani.

MINISTRY OF REGIONAL DEVELOPMENT OF THE CZECH REPUBLIC. Partnership Agreement for the Programming Period 2014-2020, Czech Republic, 2019. Available on-line at https://dotaceeu.cz/getmedia/3e0f0610-a55a-494d-883d-fd80afe90674/Dohoda-o-partnerstvi(5-revize,-duben-2019).pdf.aspx?ext=.pdf

MINISTRY OF THE ENVIRONMENT OF THE CZECH REPUBLIC. The Operational Programme Environment 2014-2020 Programming Document, 2019. Available on-line at https:/ /www.opzp.cz/dokumenty/detail/?id=1687

MINISTRY OF TRANSPORT OF THE CZECH REPUBLIC. Operational Programme Infrastructure, 2003.

Order of the Cabinet of Ministers of Ukraine of February 20, 2019 № 117-r On approval of the National Waste Management Plan until 2030. Available on-line at https://zakon.rada.gov.ua/laws/show/117-2019-\%D1\%80.

Order of the Government of November 8, 2017 No. 820-p On Approval of the National Strategy for Waste Management in Ukraine until 2030. Available on-line at https://www.kmu.gov.ua/ua/npas/250431699. 
Order of the Ministry of Housing and Communal Services of Ukraine "On Approval of the Rules for the Operation of Landfills of Household Waste" № 1307/18602 of December 22, 2010. Available on-line at https://zakon.rada.gov.ua/laws/show/z1307-10\#Text.

NECHITAYLO, D. et al. From the third world to the first. Waste management reform in Ukraine. PWC, 2020. Available online at https://www.pwc.com/ua/en/survey/2020/wastemanagement.pdf.

OECD. Data: Municipal waste. Available on-line at https://data.oecd.org/waste/municipalwaste.htm.

OECD. Environment at a Glance 2020, Paris: OECD Publishing.

OECD. Environmental Performance Reviews Czech Republic Organisation for Economic CoOperation and Development, 1999. Available on-line at https://www.oecd-

ilibrary.org/docserver/9789264172166-

en.pdf?expires $=1593435647 \& \mathrm{id}=\mathrm{id} \&$ accname $=$ ocid41017442\&checksum $=4503640584 \mathrm{~A} 30 \mathrm{C} 316$ 49910856 DA37641.

PALECEK, R. Systém nakládání s odpady v polské Zielenoj Gorze. Available online at https://www.komunalweb.cz/system-nakladani-s-odpady-v-polske-zielonej-gorze.

PIATTONI, S., POLVERARI, L. Handbook on Cohesion Policy in the EU. Edward Elgar Publishing. 2016, p.547.

PLASTICS RECYCLERS EUROPE. 20 Years Later \& The Way Forward: Making more from plastics waste, Strategy Paper 2016.

PRZEDSIĘBIORSTWO GOSPODARKI ODPADAMI EKO-MAZURY. Budowa Zakładu Unieszkodliwiania Odpadów w Siedliskach k/Ełku, 2019. Available on-line at http://ekomazury.elk.pl/inwestycje-projekty/budowa-zakladu-unieszkodliwiania-odpadow-w-siedliskach-kelku/

PRZYDATEK, G. Assessment of changes in the municipal waste accumulation in Poland. Environmental Science and Pollution Research, vol. 27(20), 2020, p. 25766-25773.; ALWAELI, M. An overview of municipal solid waste management in Poland. The current situation, problems and challenges. Environment Protection Engineering, vol. 41(4), 2015, p. 181-193.

RESPONSIBLE FUTURE. The Ukrainian government has approved a National Waste Management Plan until 2030. Available on-line at https://responsiblefuture.com.ua/ukrayinskijuryad-zatverdiv-natsionalnij-plan-upravlinnya-vidhodami-do-2030-roku/.

SAVITSKY, Y. Poles who do not sort garbage will be forced to pay. Available online at https://www.radiosvoboda.org/a/25080193.html.

SHEVCHENKO, T., KOBLIANSKA, I., MARKOVA, O. Waste portable batteries and accumulators management in compliance with European union requirements in Ukraine: Present state and high priority activities. Journal of Environmental Management and Tourism, vol. 8(1), 2017, p. 232-246.; KIDALOV, S. et al. Legal regulation of waste management in ukraine on the way to european integration. European Journal of Sustainable Development, vol. 9(2), 2020, p. 422-430.

SLAVÍK, J., RYBOVÁ, K., DOLEJŠ, M. Biowaste separation at source and its limitations based on spatial conditions. Detritus, vol. 5(March), 2019, p. 36-45.

SLOVAK REPUBLIC. Partnerská dohoda SR na roky 2014 - 2020, 2014. Available on-line at https://www.partnerskadohoda.gov.sk/zakladne-dokumenty/.

ŠAUER, P., PAŘÍZKOVÁ, L., HADRABOVÁ, A. Charging systems for municipal solid waste: Experience from the Czech Republic. Waste Management, vol. 28(12), 2008, p. 2772-2777. 
Regulation (EC) No 2150/2002 of the European Parliament and of the Council of 25 November 2002 on waste statistics. OJ L 332, p. 1-36.

Regulation (EC) No 1013/2006 of the European Parliament and of the Council of 14 June 2006 on shipments of waste. OJ L 190, p. 1-98.

Resolution No. 88 of the Council of Ministers of 1 July 2016 on the National Waste Management Plan 2022.

SANDS, P. Principles of International Environmental Law. Cambridge University Press, 2003.

SMOLÁKOVÁ, D. Ekologická katastrofa na řece Tise. Zaplavují ji tisíce tun plastového odpadu. Available online at https://udalosti247.cz/zahranici/reku-tisu-zaplavuji-tunyplastoveho-odpadu/.

STENMARCK, A., JENSEN, C., QUESTED, T., MOATES, G. Estimates of European Food Waste Levels. Swedish Environmental Research Institute, 2016.

UNITED NATIONS ENVIRONMENT PROGRAMME. Food Waste Index Report 2021, Nairobi, p. 4.

URZADD MARSZAŁKOWSKI WOJEWÓDZTWA DOLNOŚLĄSKIEGO. Regionalny Program Operacyjny Województwa Dolnośląskiego 2014-2020, 2019. Available on-line at http:// rpo.dolnyslask.pl/regionalny-program-operacyjny-wojewodztwa-dolnoslaskiego-2014$2020 /$

URZA¿D MARSZAŁKOWSKI WOJEWÓDZTWA LUBELSKIEGO W LUBLINIE. Regionalny Program Operacyjny Województwa Lubelskiego na lata 2014-2020, 2014. Available on-line at

https://rpo.lubelskie.pl/site/assets/files/1194/projekt_regionalnego_programu_operacyjnego_ wojewodztwa_lubelskiego_2014_2020_wer_3.pdf

URZĄD MARSZAŁKOWSKI WOJEWÓDZTWA MAZOWIECKIEGO. Regionalny program operacyjny Województwa Mazowieckiego 2007 - 2013, 2011. Available on-line at http://rpo.mazowia.eu/g2/oryginal/2012_02/1c01ced4116376e42bd66c05eb6d5341.pdf

URZĄD MARSZAŁKOWSKI WOJEWÓDZTWA PODLASKIEGO. Regionalny Program Operacyjny Województwa Podlaskiego na lata 2007-2013, 2016. Available on-line at http://www.rpowp.wrotapodlasia.pl/private/upload/file/41ad28912948fd45a20eed582cd98395. $\mathrm{pdf}$

URZĄD MARSZAŁKOWSKI WOJEWÓDZTWA PODLASKIEGO. Regionalny Program Operacyjny Województwa Podlaskiego na lata 2014-2020, 2020. Available on-line at https://rpo.wrotapodlasia.pl/pl/dowiedz_sie_wiecej_o_programie/zapoznaj_sie_z_prawem_i_ dokument/regionalny-program-operacyjny-wo.html

URZĄD MARSZAŁKOWSKI WOJEWÓDZTWA WARMIŃSKO-MAZURSKIEGO. Regionalny Program Operacyjny Województwa Warminsko-Mazurskiego na lata 2014-2020, 2020. Available on-line at https://rpo.warmia.mazury.pl/plik/3/regionalny-program-operacyjnywojewodztwa-warminsko-mazurskiego-na-lata-2014-2020

URZĄD MARSZAŁKOWSKI WOJEWÓDZTWA WIELKOPOLSKIEGO. Wielkopolski Regionalny Program Operacyjny na lata 2014-2020, 2020. Available on-line at https://wrpo.wielkopolskie.pl/dowiedz-sie-wiecej-o-programie/zapoznaj-sie-z-prawem-idokumentami/756

URZAZD MARSZAŁKOWSKI WOJEWÓDZTWA ZACHODNIOPOMORSKIEGO. Regionalny Program Operacyjny Województwa Zachodniopomorskiego 2014-2020, 2020. 
Available on-line at https://rpo.wzp.pl/o-programie/poznaj-program-regionalny-i-jegozasady/regionalny-program-operacyjny-wojewodztwa-zachodniopomorskiego-2014-2020

URZAD MARSZALKOWSKIEGO WOJEWÓDZTWA ŚLĄSKIEGO. Regionalny Program Operacyjny Województwa Śląskiego na lata 2007 - 2013, 2010. Available on-line at https://rpo2007-2013.slaskie.pl/zalaczniki/2010/10/07/1286452333.pdf

URZAD MIASTA POZNANIA. Straż miejska skontroluje segregację odpadów. Available online at https://www.teraz-srodowisko.pl/aktualnosci/straz-miejska-skontroluje-segregacjeodpadow-5320.html.

ZAKŁAD UTYLIZACJI ODPADÓW W SIEDLCACH. Nowy PSZOK w regionie, 2020. Available on-line at https://zuo.siedlce.pl/aktualnosci/nowy-pszok-w-regionie ; MAZOWIECKA JEDNOSTKA WDRAŻANIA PROGRAMÓW UNIJNYCH. Inwestujemy w PSZOKI, 2019. Available on-line at https://www.funduszedlamazowsza.eu/aktualnosci/inwestujemy-w-pszoki-lets-inwest-inselective-waste-points/

ZARZĄD WOJEWÓDZTWA DOLNOŚLĄSKIEGO. Regional Operational Programme for the Lower Silesian Voivodship, 2007. Available on-line at http://old.rpo.dolnyslask.pl/pliki/ROP_21_08_2007_en.pdf

ZARZĄD WOJEWÓDZTWA ŁÓDZKIEGO. Regionalny Program Operacyjny Województwa Łódzkiego na lata 2014-2020, 2020. Available on-line at https://rpo.lodzkie.pl/dowiedz-siewiecej-o-programie/zapoznaj-sie-z-prawem-i-dokumentami/item/196-regionalny-programoperacyjny-wojewodztwa-lodzkiego-na-lata-2014-2020

ZARZĄD WOJEWÓDZTWA LUBELSKIEGO. Regionalny Program Operacyjny

Województwa Lubelskiego na lata 2007-2013. Available on-line at http://www.lawp.eu/index.php?menu $=$ rpo

ZARZAূD WOJEWÓDZTWA LUBUSKIEGO. Lubuski Regionalny Program Operacyjny na lata 2007-2013, 2011. Available on-line at

http:/ /www.lrpo.lubuskie.pl/index.php?option $=$ com_content\&view $=$ category\&layout $=$ blog\&id $=80 \&$ Itemid $=151$

ZARZA¿D WOJEWÓDZTWA LUBUSKIEGO. Regionalny Program Operacyjny - Lubuskie 2020, 2020. Available on-line at https://rpo.lubuskie.pl/-/regionalny-program-operacyjnylubuskie-2020

ZARZĄD WOJEWÓDZTWA MALOPOLSKIEGO. Małopolski Regionalny Program Operacyjny na lata 2007-2013, 2016. Available on-line at

http://www.fundusze20072013.malopolska.pl/mrpo/Documents/dokumentyprogramowe/MRPO_6122016.pdf

ZARZAৃD WOJEWÓDZTWA MALOPOLSKIEGO. Regionalny Program Operacyjny Województwa Małopolskiego na lata 2014-2020, 2020. Available on-line at https://www.rpo.malopolska.pl/o-programie/zapoznaj-sie-z-prawem-idokumentami/regionalny-program-operacyjny-2014-2020

ZARZĄD WOJEWÓDZTWA OPOLSKIEGO. Regionalny Program Operacyjny Województwa Opolskiego na lata 2007-2013. Available on-line at http://archiwum.opolskie.pl/docs/rpo_wo.pdf

ZARZAZD WOJEWÓDZTWA PODKARPACKIEGO. Regionalny Program Operacyjny Województwa Podkarpackiego na lata 2007-2013, 2012. Available on-line at http:/ /rpo20072013.podkarpackie.pl/pliki/file/Dokumenty Programowe/RPO/zaktual_rpo_wp_12_2011.pdf 
ZARZAZD WOJEWÓDZTWA PODKARPACKIEGO. Regionalny Program Operacyjny Województwa Podkarpackiego na lata 2014-2020, 2020. Available on-line at https://www.rpo.podkarpackie.pl/index.php/dokumenty-programowe/278-regionalnyprogram-operacyjny-wojeodztwa-podkarpackiego-na-lata-2014-2020

ZARZAZD WOJEWÓDZTWA POMORSKIEGO. Regionalny Program Operacyjny dla Województwa Pomorskiego na lata 2007-2013, 2010. Available on-line at https:/ /www.arp.gda.pl/plik,3111,regionalny-program-operacyjny-dla-wojewodztwapomorskiego-na-lata-2007-2013-rpo-wp-2007-2013-wrzesien-2010.pdf

ZARZACD WOJEWÓDZTWA POMORSKIEGO. Regionalny Program Operacyjny Województwa Pomorskiego na lata 2014-2020, 2018. Available on-line at https://www.rpo.pomorskie.eu/-/rpo-wp-2014-2020-zmiana-05-07-2018

ZARZĄD WOJEWÓDZTWA ŚLĄSKIEGO. Regionalny Program Operacyjny Województwa Śląskiego na lata 2014-2020, 2020. Available on-line at https://rpo.slaskie.pl/dokument/regionalny_program_operacyjny_wojewodztwa_slaskiego_na_l ata_2014_2020_aktualizacja_v5

ZARZĄD WOJEWÓDZTWA ŚWIĘTOKRZYSKIEGO. Regionalny Program Operacyjny Województwa Świętokrzyskiego 2014-2020, 2020. Available on-line at http:/ /www.20142020.rpo-swietokrzyskie.pl/dowiedz-sie-wiecej-o-programie/zapoznaj-sie-z-prawem-idokumentami/dokumenty-regionalne/item/152-regionalny-program-operacyjny-wojewodztwaswietokrzyskiego-na-lata-2014-2020

ZARZĄD WOJEWÓDZTWA ŚWIĘTOKRZYSKIEGO. Szczegółowy opis osi priorytetowych Regionalnego Programu Operacyjnego Województwa Świętokrzyskiego na lata 2007 - 2013, 2009. Available on-line at https://www.funduszeeuropejskie.2007-

2013.gov.pl/dokumenty/zmianywdokumentach/documents/uszczegolowienie_rpo_swietokrzys kie_11_09.pdf

ZARZA¿D WOJEWÓDZTWA WARMIŃSKO-MAZURSKIEGO. Regionalny Program Operacyjny Warmia i Mazury na lata 2007-2013, 2012. Available on-line at http://rpo.0713.warmia.mazury.pl/index.php?page $=$ dzial\&dzial_id $=79$

ZARZĄD WOJEWÓDZTWA ZACHODNIOPOMORSKIEGO. Regionalny Program Operacyjny Województwa Zachodniopomorskiego na lata 2007-2013, 2016. Available on-line at http://rpo2007-2013.wzp.pl/rpo/regionalny_program_operacyjny/p-r-m-a-

24632/regionalny_program_operacyjny.htm

ZEBEK, E., SZWEJKOWSKA, M., RACZKOWSKI, M. Legal and organisational solutions of municipal waste management in Poland in compliance with waste directive 2008/98/EC. Journal of Environmental Protection and Ecology, vol. 16(2), 2015, p. 652-658.

ZICHA, J., GOLOVKO, L. Legislation of the European Union Related to Municipal Waste and its Reflection in the Association Agreement with Ukraine. Law - Human - Environment, vol. 10(4), 2019, p. 180-186. 
Title:

Management of Municipal Waste in the EU Member States: Best Practices

Authors:

JUDr. Jiř́ Zicha, Ph.D., Ing. Lenka Smékalová, Ph.D., JUDr. Olga Kapplová, Ph.D. - Tomas Bata University in Zlin

Dr. Liudmyla Golovko, Ph.D. - National University of Life and Environmental Sciences of Ukraine

Graphic design and typesetting: Jiř́ Zicha

Publisher: Tomas Bata University in Zlin, 2021

Order of issue: First

Issued electronically

Scientific editor: doc. Ing. Adriana Knápková, Ph.D.

Reviewers: Dr. Viktoriia Halai, Ph.D., JUDr. Ondřej Vícha, Ph.D.

ISBN 978-80-7678-055-2 